2. To: (Feceiving Organization)
PNNL

5. Proj./Prog./Dept./Div.:

EM-50/WT
8. Originator Renarks:

Cesium Removal Test Procedures/Instructions for Approval/Release. This document follows the Test Plan issued under EDT \# 611422.

11. Receiver Remarks:

3. From: (Originating Organization)
SESC/PE
6. Cog. Engr.:
D. W. Hendrickson

4. Related EDT Non:

611422

7. Purchase Order No.: NA

9. Equip_/Component No.: NA

10. System/Bldg./Facility:

$$
\text { 222-S \& 306E }
$$

12. Major Assm. Dwg. No.: NA

13. Permit/Permit Application No.: NA

14. Required Response Date: 9 January 1997

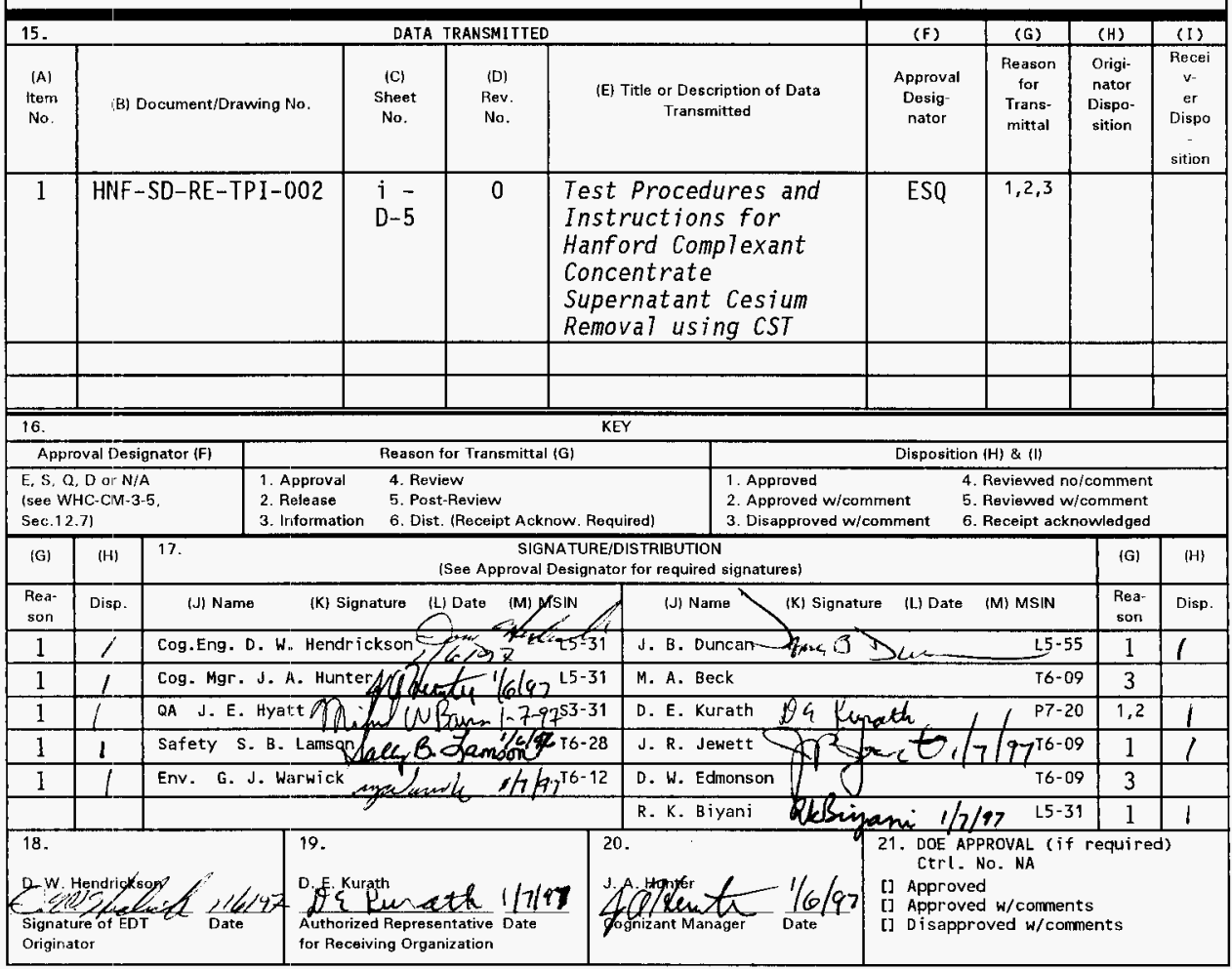




\title{
Test Procedures and Instructions for Hanford Complexant Concentrate Supernatant Cesium Removal using CST
}

\author{
R. K. Biyani \\ J. B. Duncan \\ D. W. Hendrickson \\ SGN Eurisys Services Corporation, Richland, WA 99352 \\ U.S. Department of Energy Contract DE-AC06-96RL13200 \\ EDT/ECN: $605786 \quad$ UC: 2020 \\ Org Code: YA400000 Charge Code: BE1884 \\ B\&R Code: $820201000 \quad$ Total Pages: 97
}

Key Words: Hanford, Tank Waste, Complexant Concentrate, Cesium, Ion Exchange, Radioactive, IE-911, Crystalline Silicotitanate

Abstract: This document provides specific test procedures and instructions to implement the test plan for the preparation and conduct of a cesium removal test, using Hanford Complexant Concentrate supernatant liquor from tank 241-AN-107, in a bench-scale column. The cesium sorbent to be tested is crystalline silicotitanate. The test plan for which this provides instructions is WHC-SD-RE-TP-023, Hanford Complexant Concentrate Supernatant Cesium Removal Test Plan.

TRADEMARK DISCLAIMER. Reference herein to any specific commercial product, process, or service by trade name, trademark, manufacturer, or otherwise, does not necessarily constitute or imply its endorsement, recommendation, or favoring by the United States Government or any agency thereof or its contractors or subcontractors.

Printed in the United States of America. To obtain copies of this document, contact: LMSI Document Control Services, P.O. Box 950, Mailstop H6-08, Richland WA 99352, Phone (509) 372-2420; Fax (509) 376-4989.

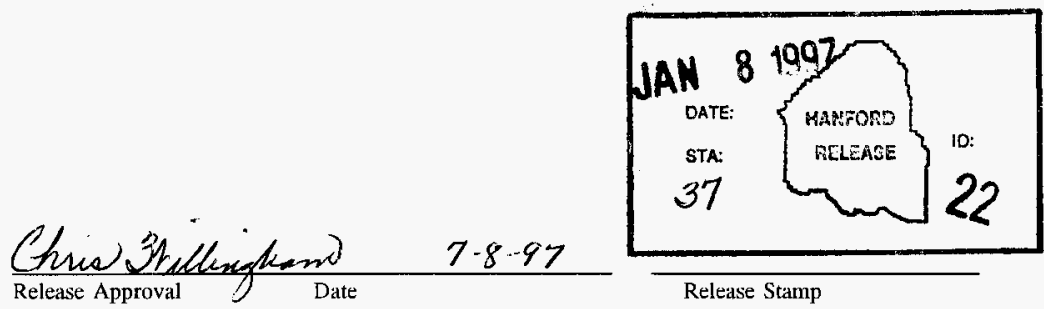


HNF-SD-RE-TPI-002, Rev. 0

THIS PAGE INTENTIONALLY LEFT BLANK 


\section{TABLE OF CONTENTS}

1.0 INTRODUCTION

2.0 DESCRIPTION OF TEST $\ldots \ldots \ldots \ldots \ldots \ldots \ldots \ldots \ldots$

2.1 TEST ENVIRONMENT . . . . . . . . . . . . . . . 3

2.2 MATERIAL AND EQUIPMENT NEEDS $\ldots \ldots \ldots \ldots \ldots \ldots \ldots$

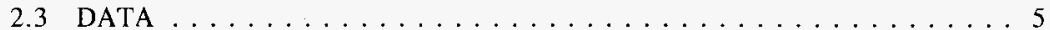

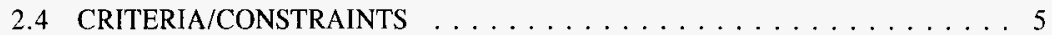

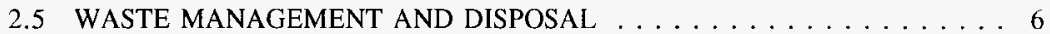

3.0 EXPECTED RESULTS $\ldots \ldots \ldots \ldots \ldots \ldots \ldots \ldots \ldots$

4.9 TEST PROCEDURE . . . . . . . . . . . . . . . . . 7

4.1 SYSTEM ACCEPTANCE TESTING AND CALIBRATIONS . . . . . . 7

4.1 .1 Equipment Assembly $\ldots \ldots \ldots \ldots \ldots \ldots \ldots \ldots$

4.1.1.1 Feed Assembly $\ldots \ldots \ldots \ldots \ldots \ldots \ldots$

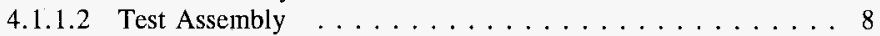

4.1.2 Testing in Cold Environment $\ldots \ldots \ldots \ldots \ldots \ldots \ldots \ldots$

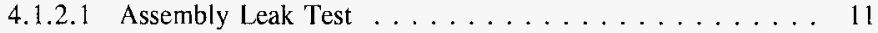

4.1 .3 Reagent Preparation . . . . . . . . . . . . . . 13

4.1.4 Exchange Material Dissolution $\ldots \ldots \ldots \ldots \ldots \ldots \ldots \ldots$

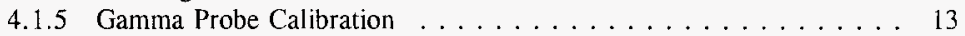

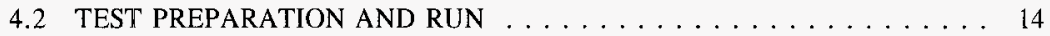

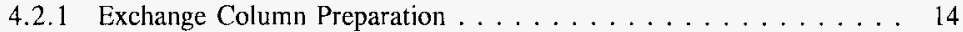

4.2 .2 CST Apparatus Pump Curve Acquisition $\ldots \ldots \ldots \ldots \ldots \ldots 14$

4.2.3 CST Waste Feed Preparation and Analysis . . . . . . . . . 15

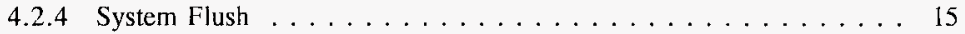

4.2.5 Cesium Removal Test Run . . . . . . . . . . . . . . . . 16

4.2.5.1 Gamma Detector Data Logging . . . . . . . . . 16

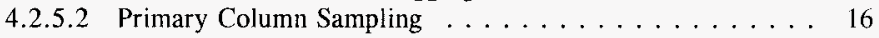

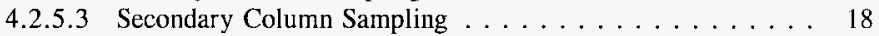

4.2.5.4 System Effluent Sampling . . . . . . . . . . . . . . . 19

4.2.5.5 Run Execution . . . . . . . . . . . . . . . . . . 19

4.2 .6 System Flush . . . . . . . . . . . . . . . . 20

4.3 SYSTEM CLEANOUT AND WASTE MANAGEMENT $\ldots \ldots \ldots \ldots . \ldots 20$

4.3.1 Thermolabile Wastes $\ldots \ldots \ldots \ldots \ldots \ldots \ldots \ldots \ldots \ldots$

4.3.2 Sorbent Columns . . . . . . . . . . . . . . . . . 20

4.3 .3 Other Liquors . . . . . . . . . . . . . . . . . . . . . 21

4.3.4 Other Solid Wastes . . . . . . . . . . . . . . . . . . 21

4.4 SAMPLING AND SAMPLE ANALYSES $\ldots \ldots \ldots \ldots \ldots \ldots \ldots$ 
TABLE OF CONTENTS - continued

PAGE

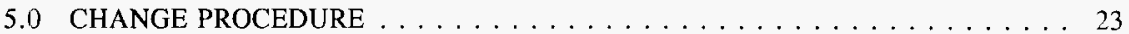

5.1 General Changes . . . . . . . . . . . . . . . . . . 23

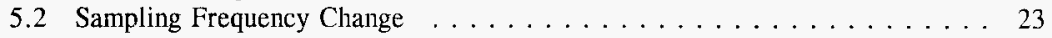

5.3 Pump Flow Rate Reset $\ldots \ldots \ldots \ldots \ldots \ldots \ldots$

6.0 QUALITY ASSURANCE $\ldots \ldots \ldots \ldots \ldots \ldots \ldots \ldots \ldots \ldots \ldots \ldots$

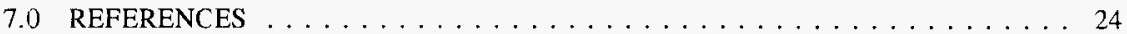

\section{LIST OF APPENDICES}
A: Checksheets and Data Sheets
B: Material Safety Data Sheets
C: Valving Configuration Figures
D: Gamma Probe Operation

\section{LIST OF FIGURES}

PAGE

Figure 1: Bench-Scale Cesium Exchange Flows and Instrumentation . . . . . . . . . 2

Figure 2: Physical Test Assembly Valve and Column Arrangement . . . . . . . . . 3

Figure A-1: Bench-Scale Cesium Exchange Flows and Instrumentation . . . . . . A A-1

Figure A-2: Physical Test Assembly Valve and Column Arrangement . . . . . . . . . A A-2

Figure C-1: Config. 1A, Primary Column (Cla) Full System Feed Valving . . . . . . . C-1

Figure C-2: Config. 1B, Backup Column (C1b) Full System Feed Valving . . . . . . . . . C-1

Figure C-3: Config. 2A, Forward Feed through Primary and First Guard Columns . . . C C-2

Figure C-4: Config. 2B, Forward Flow Through Backup and First Guard Columns . . . C C-2

Figure C-5: Config. 3A, Forward Flow Through Primary (C1a) Column to Sample . . . C C-3

Figure C-6: Config. 3B, Forward Flow Through Backup (C1b) Column to Sample . . . . C-3

Figure C-7: Config. 4A, Forward Flush Bypass to Line 12A . . . . . . . . . . C-4

Figure C-8: Config. 4B, Forward Flush Bypass to Line 12B . . . . . . . . . . . . C-4

Figure C-9: Config. 5A, Reverse Flush Through Primary (C1a) Column . . . . . . . C-5

Figure C-10: Config. 5B, Reverse Flush Through Backup (Clb) Column . . . . . . . C-5

Figure C-11: Config. 6, Reverse Flush Through Guard Columns (C3 and C2) . . . . . C-6 


\section{LIST OF TABLES}

PAGE

Table 1: Reagent Densities at Experimental Temperature . . . . . . . . . . . . 5

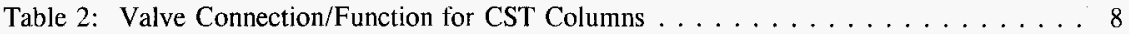

Table 3: CST Test Run Primary Column Sampling . . . . . . . . . . . . . 18

Table 4: CST Test Run Secondary Column Sampling . . . . . . . . . . . . . . . . . . 19

Table 5: Cesium Ion Exchange Summary Sample Analysis Plan $\ldots \ldots \ldots \ldots . \ldots .21$

\section{LIST OF APPARATUS FLOW CONFIGURATIONS}

PAGE

Config. 1: Full System Forward Feed Valving Configuration

(Forward flow to Line 11) . . . . . . . . . . . . . . 10

Config. 2: First Guard Column Forward Feed Valving Configuration

(Forward flow to Line 14) . . . . . . . . . . . . . . . . . . . 10

Config. 3: Lead Column Forward Feed Valving Configuration

(Forward flow to Line 13) . . . . . . . . . . . . . . . 11

Config. 4: CST Pump Flow Rate Calibration Valve Configuration

(Foward flush bypass to Line 12A/B) . . . . . . . . . . . . 11

Config. 5: Column Cla/b Reverse Flush Valving Configuration

(Reverse flush to Line 12A/B) $\ldots \ldots \ldots \ldots \ldots \ldots \ldots \ldots$

Config. 6: Reverse Feed Valving Configuration

(Reverse flush through guard columns) $\ldots \ldots \ldots \ldots \ldots \ldots \ldots$ 
HNF-SD-RE-TPI-002, Rev. 0

THIS PAGE INTENTIONALLY LEFT BLANK 


\section{Test Procedures and Instructions for Hanford Complexant Concentrate Supernatant Cesium Removal using CST}

\subsection{INTRODUCTION}

Cesium-137 $\left({ }^{137} \mathrm{Cs}\right)$ is a primary radiation source in the dissolved tank waste at the Hanford Site. ${ }^{137} \mathrm{Cs}$ removal from the waste can reduce the hazard and waste classification of the low level waste and reduce treatment and disposal costs.

The object of these test procedures is to conduct a test of cesium sorption of actual Hanford tank waste with materials which have been proposed for development and potential deployment in Hanford Site waste treatment. Treated effluent from these tests is proposed to be received by Battelle Pacific Northwest National Laboratory to conduct technetium sorption studies in further support of site waste treatment needs.

These procedures are written to directly meet the procedural needs of the Hanford Complexant Concentrate Supernatant Cesium Removal Test Plan (Hendrickson et al. 1996b) to ensure adequacy of conduct and collection of appropriate samples and data.

This work is funded by the U.S. Department Of Energy Office of Science and Technology Tanks Focus Area under Technology Task Plan (TTP) RL37WT42 Cesium Flow Studies at Hanford through Pacific Northwest National Laboratory (PNNL). This task was previously identified under TTP \# RL07WT42.

\subsection{DESCRIPTION OF TEST}

For this cesium ion exchange test, a test apparatus will be constructed, functionally tested, then placed in a hot cell within the 222-S Laboratory. Approximately five liters of drainable Complexant Concentrate (CC) supernatant liquor from Hanford Tank 241-AN-107 will be acquired through the sampling efforts of the TWRS Characterization Project at Hanford (Hohl 1996) and will be placed in the hot cell with the test apparatus. The CC supernatant liquor will be diluted with a dilute caustic solution to a concentration target of five molar sodium, mixed, settled, decanted, centrifuged or filtered to remove particles, and then placed in the feed tank(s) to be used as the feed for the column flow test. The test will be conducted using the checksheets and data sheets provided in Appendix A.

The test apparatus will contain a primary test column, a backup test column (in case of fouling) and two scavenging (guard) columns in series to reduce any cesium remaining in the effluent. All columns will be packed with crystalline silicotitanate (CST). The effluent is intended to be 
provided to subsequent Tanks Focus Area (TFA) tasks which will require the material for

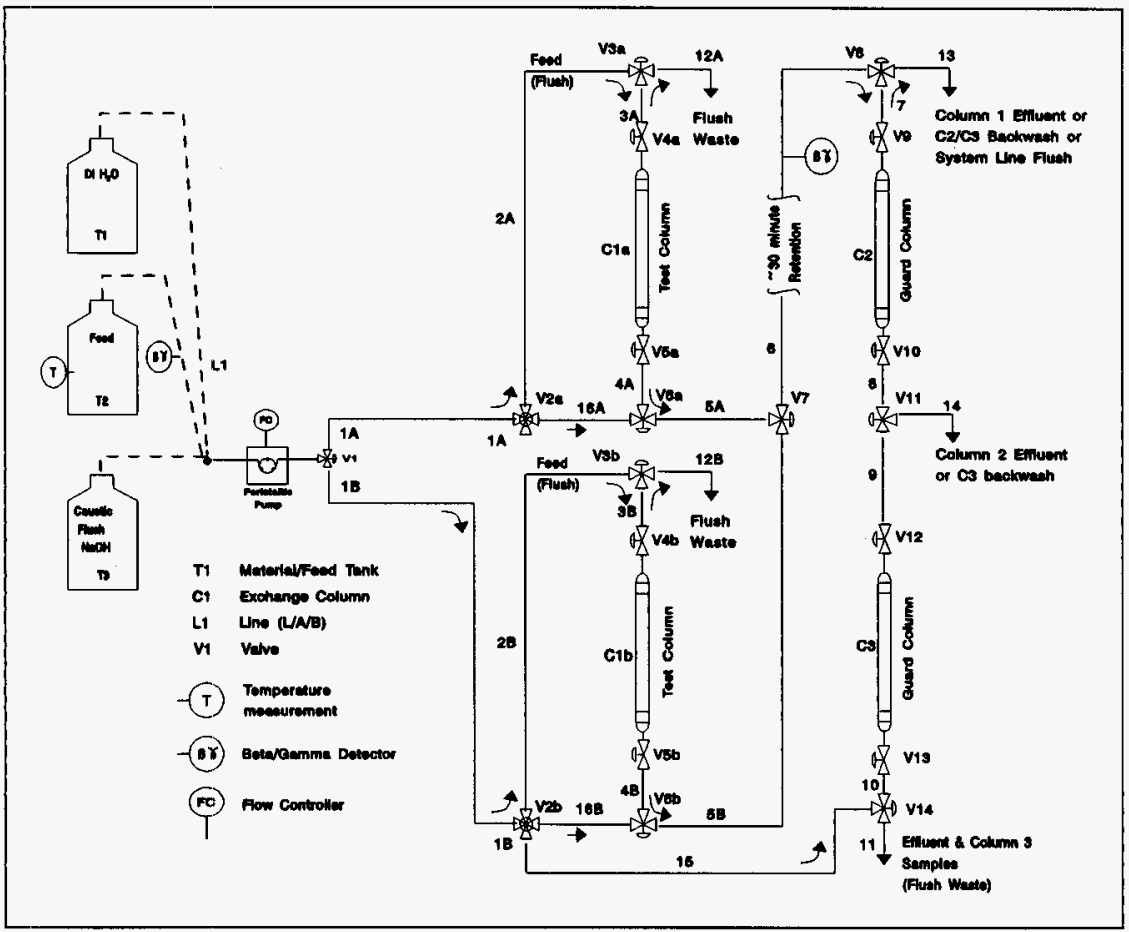

Figure 1: Bench-Scale Cesium Exchange Flows and Instrumentation

technetium (Tc) removal studies. A sketch of the process flows and instrumentation is provided in Figure 1. Physical layout of the test apparatus is provided in Figure 2.

During the loading phase of the column test, the feed solution will be pumped from the feed tank downward through a test column of cesium sorbent. The effluent from the test column will be monitored on-line for cesium breakthrough and will be sampled periodically. Samples will also be taken of the feed and guard column effluent, and digested sorbent as necessary. Sample analysis will be performed to determine the concentration of analytes to which the cesium ion exchange and vitrification processes are sensitive. These analytes include: cesium-137, total cesium, strontium, sodium, potassium, rubidium, aluminum, phosphorus (for phosphate), chromium, and iron as well as the $\mathrm{pH}$ of the sample. The feed temperatures will be recorded at the beginning and during the test.

After cesium breakthrough is detected in the test column, it will be flushed and drained, 
removed from the system, digested, sampled, and disposed. Initial plans for the spent CST are

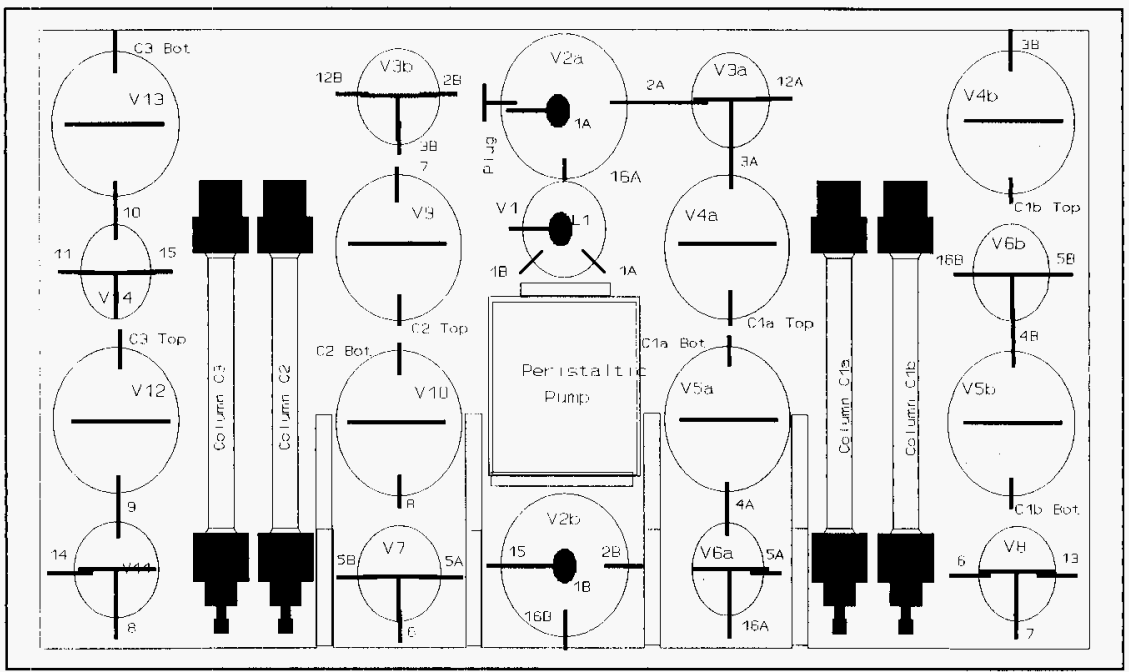

Figure 2: Physical Test Assembly Valve and Column Arrangement

in-cell digestion and disposal due to the high shielding requirements and limited capacity of manipulators entailed with removal from the hot cell (Hendrickson, et al. 1996b).

The performance of the sorbents in the removal of cesium from $\mathrm{CC}$ waste, and process considerations of such removal, will be evaluated and reported in the test report.

\subsection{TEST ENVIRONMENT}

The test environment is primarily that of Hanford's 222-S analytical laboratories.

Assembly of the test equipment is largely anticipated to occur in the 306E laboratories (300 Area) followed by acceptance testing in non-radioactive portions of the 222-S laboratories (building 222-SA). The exchange equipment will be placed into a high-radiation hot cell (probably $1 \mathrm{~F}$ ) of the 222-S laboratory where the process tests will occur.

Waste material grab sample bottles, will be retrieved from tank 241-AN-107, brought to the 22.2-S laboratory and transferred to a hot cell for testing.

With the exception of sample analyses at the 222-S laboratory or the Battelle Pacific Northwest National Laboratory 325 laboratory, all tests will be done within a hot cell at 222-S. 


\subsection{MATERIAL AND EQUIPMENT NEEDS}

Equipment needed for the apparatus assembly includes:

2 Exchange Columns, glass, $0.7 \mathrm{~cm}$ internal diameter (ID), packing height $7 \mathrm{~cm}$.

2 Exchange Columns, glass, $1 \mathrm{~cm}$ internal diameter (ID), packing height $10 \mathrm{~cm}$.

8 column clamps for exchange column retention

1 Peristaltic pump, flow range from 7 to $42 \mathrm{~mL} / \mathrm{hr}$

8 gate valves, $\sim 3 \mathrm{~mm}$ ID, Teflon ${ }^{1}$ core

9 T-valves, $\sim 3 \mathrm{~mm} \mathrm{ID,} \mathrm{Teflon} \mathrm{core}$

2 four way valves, $-3 \mathrm{~mm}$ ID, Teflon core

$5 \mathrm{~m}$ Tygon ${ }^{2}$ tubing, $0.51 \mathrm{~mm}, 0.89 \mathrm{~mm}, 1.59 \mathrm{~mm}, 3.2 \mathrm{~mm}$, and $4.8 \mathrm{~mm}$ ID

1 Waste Feed Tank (T2), polyethylene, $3.8 \mathrm{~L}$

1 Plug, predrilled, for $\mathrm{T} 2,3.8 \mathrm{~cm}$ diameter

4 Waste Feed Bottles, polyethylene, 1L

2 Feed Reagent Tank, polyethylene, I L $\left(0.220 \underline{\mathrm{M} \mathrm{NaOH}}\right.$, DI $\left.\mathrm{H}_{2} \mathrm{O}\right)$

6 Effluent Receivers, polyethylene, $1 \mathrm{~L}$

1 Flush receiver, glass jar, $250 \mathrm{~mL}$

1 Shears for cutting large feed reagent tanks

52 Glass sample vials with lids, $-20 \mathrm{~mL}$

12 Centrifuge cones, glass, $50 \mathrm{~mL}$

4 sample carriers

1 Continuous $\gamma$ detector and recorder

1 thermometer

1 Rurtime clock

1 Sample clock/stop watch

$100 \mathrm{~g}$ CST engineered exchange material (MSDS in Appendix B)

$1 \quad$ Hot/stir plate with stir bars

Reagents required (for Material Safety Data Sheets, see Appendix B), and anticipated volumes include:

$\begin{array}{lll}\text { Deionized Water } & 10.0 & \text { Liters } \\ \text { Sodium Hydroxide (NaOH), 5.0 } \underline{\mathrm{M}} & 2.0 & \text { Liters } \\ \text { Hydrofluoric Acid (HF), 1 } \underline{\mathrm{M}} & 0.125 & \text { Liter } \\ \text { Hydrochloric Acid (HCl), } 2 \underline{\mathrm{M}} & 0.25 & \text { Liter } \\ \text { Tank Waste, 241-AN-107 } & 5.0 & \text { Liters }\end{array}$

Facilities required are those of the $222-\mathrm{S}$ laboratory $1 \mathrm{~F}$ hot cell, and nonradiological portions of 222-S and 306E for equipment assembly and acceptance testing.

Teffon is a trademark of E. I. duPont de Nemours, Co., Wilmington, DE.

Tygon is a trademark of Norton Performance Plastics, Akron, OH. 
Table 1: Reagent Densities at Experimental Temperature

\begin{tabular}{||l|l|r||}
\hline \hline Reagent & \multicolumn{1}{|c|}{ Molar } & $\begin{array}{c}\text { Density } \\
(\mathrm{g} / \mathrm{mL}) 27^{\circ} \mathrm{C}\end{array}$ \\
\hline $\mathrm{HF}$ & 1 & 0.998 \\
\hline $\mathrm{HCl}$ & 2 & 1.031 \\
\hline $\mathrm{H}_{2} \mathrm{O}$ & 55.51 & 0.997 \\
\hline $\mathrm{NaOH}$ & 0.22 & 1.0060 \\
\hline $\mathrm{NaOH}$ & 0.4689 & 1.0166 \\
\hline $\mathrm{NaOH}$ & 5.0 & 1.1820 \\
\hline
\end{tabular}

Source: Perry's Chemical Engineer's Handbook, Sixth Edition, R. H. Perry, D. W. Green, J. O. Maloney, McGraw-Hill Book Company, New York, New York, 1984.

Additional or differing equipment and reagents may be applied at the discretion of operating personnel with concurrence of the lead scientist or engineer. Change procedures are provided in $\$ 5.0$. A detail of equipment and reagents used in conduct will be provided in the test report.

\subsection{DATA}

Parameters to be measured, and the precision required is, in large part, defined in the subtask. In general, the parameters of measurement, when not in chemical assay, are those of interval, volume, mass, and gamma decay. In-cell sample masses should be measured to three significant digits, runtimes should be reported in tenths of minutes, sample intervals (by stop watch) should be recorded in tenths of seconds. The subtasks to be described and executed herein are waste feed preparation exchange column packing, activation, flush, operation, sampling, and waste material handling. Chemical assay quality assurance is described by Meznarich (1995). Quality assurance for the conduct of the unit operations and hot cell activities will be in accordance with the approved process testing quality assurance plan (Meznarich 1996). Data Sheets and checksheets for operation are provided in Appendix A. Completed datasheets and checksheets will be entered into appropriate logbooks. 222-S chemical assay analyses will be stored in the laboratory information management system, LabCore.

\subsection{CRITERIA/CONSTRAINTS}

This is a treatability test whose activities are governed by WAC 173-303-071(3)(r) [Treatability Study Samples] and WAC 173-303-071(3)(s) [Samples undergoing treatability studies at laboratories and testing facilities] thereby generating a requirement that the Washington State Department of Ecology (WDOE) be notified, in writing, of the intent to conduct treatability studies no less than 45 days prior to conducting the studies. Treatment of actual waste in the test apparatus shall not proceed unless such a notice compliant with WAC 173-303-071(s)(i) is submitted. (WDOE 1994) As described by the test plan 
(Hendrickson et al. 1996b), compliance with these provisions has been met with the 1988 notification.

ALARA principles shall guide all actions in this test.

\subsection{WASTE MANAGEMENT AND DISPOSAL}

Wastes from the conduct of this test scope will include spent extraction media, extraction columns, sample bottles, feed bottles (tanks), tygon tubing, valves, waste liquor, treatment effluent, and sampling wastes. All materials having contacted the tank waste liquor must be considered mixed wastes as the tank wastes have been designated to contain F-listed solvents (EPA 1986). To the greatest extent possible, bottles containing wastes brought into the hot cell will be of polyethylene so that they may be melted down within the cell following use. The extraction media will be dissolved, sampled, and poured down the hot cell drain. Excess and spent samples, and undispositioned effluent will be disposed per 222-S laboratory procedures. Glass vessels will be decontaminated and removed from the cell for appropriate waste disposal.

Preliminary dose models (Hendrickson and Duncan 1996) for a similar recent test indicate that shielding sufficient to reduce dose to the 222-S laboratory administrative requirement of $10 \mathrm{mR} / \mathrm{hr}$ would exceed the $18 \mathrm{~kg}(40 \mathrm{lb}$ ) capacity of the cell manipulators. As such, it is not considered safe to remove these materials from the hot cell intact.

\subsection{EXPECTED RESULTS}

This test will demonstrate the cesium selectivity and load capacity of CST using actual Hanford $\mathrm{CC}$ waste. This information will be compared to similar data gathered using simulants and will be used to validate the simulant data's use in designing a cesium removal pretreatment process.

Success of these tests will be in the form of chemical analysis and automatic gamma sample counts demonstrating rise in concentration of the effluent cesium beyond $50 \%$ of inlet concentration (breakthrough, $\lambda_{50}$ ) such that the number of column volumes processed at breakthrough be determinable on a constant slope.

Guidance from the CST developers indicates that treatment expectation for the CST sorbent is approximately 1500 column volumes of $\mathrm{CC}$ waste feed to $\lambda_{50}$. Due to the uncertainty of this expectation, on-line gamma detection capability will be required to ensure adequate sampling to describe the effluent profile. 


\subsection{TEST PROCEDURE}

This test procedure is partitioned into three primary subdivisions: system acceptance testing and calibration; CST test run preparation and cesium loading; system flush, necessary decontamination, and waste management. Sampling procedures are a component of each of these subdivisions of the test and are provided as a fourth component of the test.

Laboratory instruction, as necessary will be developed to implement these laboratory 222-S procedures.

Initial pump calibration and sorbent conditioning will be conducted in non-radiological facilities. Thus portions of test through conditioning $(\$ 4.2 .1)$ will be conducted prior to hot cell entry of the assembly. Subsequent work will be conducted in the sequence specified by this document unless modified through change procedure $(\S 5.0)$. All checksheets and data sheets are provided in Appendix A.

\subsection{SYSTEM ACCEPTANCE TESTING AND CALIBRATIONS}

The flow system apparatus (apparatus is defined as the entire system to include pumps, valving, plumbing, and columns without the exchange material) will be assembled in the nonradiological $306 \mathrm{E}$ laboratories in the 300 Area.

The valving, piping, tubing, columns, and exchange material will be the same that will be used in the hot cell in 222-S laboratory and shall follow the schematic as shown in Figure 1. Physical layout is depicted in Figure 2. The assembly of the apparatus in a cold area will be followed by conditioning and loading of the exchange material in the columns per manufacturer's specifications. With the exception of $\S 4.1 .5$, acceptance testing and calibration will be nonradiological activities.

\subsubsection{Equipment Assembly}

Equipment assembly consists of assembling the tubing, fittings, valves, pump and columns to meet the test needs. Fabrication of the substrate and basin of the test apparatus is conducted separately and prior to this assembly. Checksheets and assembly instructions are provided in Appendix A.

\subsubsection{Feed Assembly}

The ion exchange columns will be loaded and the CST conditioned in preparation for actual waste flow. The conditioning will be accomplished as outlined in section 4.2.1.

The polyethylene feed bottles, for deionized water (T1), waste feed (T2), and $0.220 \underline{\mathrm{M}}$ $\mathrm{NaOH}$ (caustic flush, T3), will share one line (L1) to the peristaltic pump (Figure 1). The discharge line from the peristaltic pump will connect to a three connection valve (V1). The line diameter selected for the pump mid-range has an ID of $0.51 \mathrm{~mm}$. There will be two lines connected from $\mathrm{V} 1$ to the test columns, the $1 \mathrm{~A}$ line to the primary column and the $1 \mathrm{~B}$ 
line to the backup column.

No assembly is required for the feed tanks, thus feed assembly shall consist of assembling line $\mathrm{L} 1$ and mounting it through the pump to valve V1. Use Sheet 1 for feed assembly directions, imagery, and checksheet.

\subsubsection{Test Assembly}

The test assembly shall be completed using Sheet 2 . The function of all valve configurations are detailed in Table 2.

Table 2: Valve Connection/Function for CST Columns

\begin{tabular}{|c|c|c|c|}
\hline Valve & After & Before & Function \\
\hline \multirow{2}{*}{ V1 } & \multirow{2}{*}{$\begin{array}{c}\text { Peristaltic } \\
\text { Pump }\end{array}$} & $\mathrm{V} 2 \mathrm{a}$ & Connects pump to Test bed $\mathrm{Cla}$ \\
\hline & & $\mathrm{V} 2 \mathrm{~b}$ & Connects pump to backup Test bed Clb \\
\hline \multirow{2}{*}{ V2a } & \multirow{2}{*}{ V1 } & V3a & Directs Feed to C1a \\
\hline & & V6a & Directs Reverse Flush to $\mathrm{C} 1 \mathrm{a}$ \\
\hline \multirow{3}{*}{ V3a } & \multirow{2}{*}{$\mathrm{v} 2 \mathrm{a}$} & $\mathrm{V} 4 \mathrm{a}$ & Directs Feed to C1a \\
\hline & & $\mathrm{NA}$ & Forward feed bypass to Line $12 \mathrm{~A}$ \\
\hline & $\mathrm{V} 4 \mathrm{a}$ & NA & C1a Reverse Flush flow to receiver \\
\hline \multirow{3}{*}{$\mathrm{V} 2 b$} & \multirow{3}{*}{$\mathrm{V} 1$} & $\mathrm{~V} 3 \mathrm{~b}$ & Directs Feed to $\mathrm{Clb}$ \\
\hline & & V6b & Directs Reverse Flush to $\mathrm{C} 1 \mathrm{~b}$ \\
\hline & & V14 & Guard Column Reverse Flow \\
\hline \multirow{3}{*}{ V3b } & \multirow{2}{*}{$\mathrm{V} 2 \mathrm{~b}$} & V4b & Directs Feed to C1b \\
\hline & & NA & Forward feed bypass to Line $12 \mathrm{~B}$ \\
\hline & $\mathrm{V} 4 \mathrm{~b}$ & $\mathrm{NA}$ & Clb Reverse Flush flow to receiver \\
\hline \multirow{2}{*}{$\mathrm{V} 4 \mathrm{a}$} & $\mathrm{V} 3 \mathrm{a}$ & C1a & Column C1a isolation, forward \\
\hline & C1a & $\mathrm{V} 3 \mathrm{a}$ & Column $\mathrm{Cla}$ isolation, reverse \\
\hline \multirow{2}{*}{$\mathrm{V} 4 \mathrm{~b}$} & V3b & $\mathrm{C} 1 \mathrm{~b}$ & Column $\mathrm{C} 1 \mathrm{~b}$ isolation, forward \\
\hline & $\mathrm{C} 1 \mathrm{~b}$ & V3b & Column $\mathrm{Clb}$ isolation, reverse \\
\hline \multirow{2}{*}{ V5a } & C1a & V6a & Column Isolation, Forward \\
\hline & V6a & $\mathrm{Cla}$ & Column Isolation, Reverse \\
\hline
\end{tabular}


Table 2: Valve Connection/Function for CST Columns

\begin{tabular}{|c|c|c|c|}
\hline Valve & After & Before & Function \\
\hline \multirow{2}{*}{ V5b } & $\mathrm{C} 1 \mathrm{~b}$ & V6b & Column Isolation, Forward \\
\hline & V6b & C1b & Column Isolation, Reverse \\
\hline \multirow{2}{*}{ V6a } & V5a & V7 & Directs Flow forward to V7 \\
\hline & $\mathrm{V} 2 \mathrm{a}$ & V5a & Directs reverse flush to $\mathrm{Cla}$ \\
\hline \multirow{2}{*}{ V6b } & V5b & $\mathrm{V7}$ & Directs Flow forward to V7 \\
\hline & $\mathrm{V} 2 \mathrm{~b}$ & V5b & Directs reverse flush to $\mathrm{Clb}$ \\
\hline \multirow{2}{*}{ V7 } & V6a & V8 & Forward flow from $\mathrm{Cla}$ to $30 \mathrm{~min}$ \\
\hline & V6b & V8 & Forward flow from $\mathrm{C} 1 \mathrm{~b}$ to $30 \mathrm{~min}$ \\
\hline \multirow{2}{*}{ V8 } & V7 & v9 & Directs feed to $\mathrm{C} 2$ \\
\hline & V7 & NA & Directs $\mathrm{C} 1 \mathrm{a} / \mathrm{b}$ effluent or $\mathrm{C} 2 / \mathrm{C} 3$ \\
\hline \multirow{2}{*}{ v9 } & V8 & $\mathrm{C} 2$ & Column $\mathrm{C} 2$ isolation, forward \\
\hline & $\mathrm{C} 2$ & V8 & Column $\mathrm{C} 2$ isolation, reverse \\
\hline \multirow{2}{*}{ V10 } & $\mathrm{C} 2$ & V11 & Column $\mathrm{C} 2$ isolation, forward \\
\hline & V11 & $\mathrm{C} 2$ & Column $\mathrm{C} 2$ isolation, reverse \\
\hline \multirow{3}{*}{ V11 } & V10 & V12 & Forward flow to Column C3 \\
\hline & V10 & NA & Directs C2 effluent to receiver \\
\hline & V12 & V10 & Directs flush to $\mathrm{C} 2$ \\
\hline \multirow{2}{*}{ V12 } & V11 & $\mathrm{C} 3$ & Column C3 isolation, forward \\
\hline & $\mathrm{C} 3$ & V11 & Column $\mathrm{C} 3$ isolation, reverse \\
\hline \multirow{2}{*}{ V13 } & $\mathrm{C} 3$ & V14 & Column $\mathrm{C} 3$ isolation, forward \\
\hline & V14 & $\mathrm{C} 3$ & Column $\mathrm{C} 3$ isolation, reverse \\
\hline \multirow{3}{*}{ V14 } & V13 & NA & Column C3 effluent and samples \\
\hline & $\mathrm{V} 2 \mathrm{~b}$ & V13 & Directs backwash to $\mathrm{C} 3$ \\
\hline & $\mathrm{V} 2 \mathrm{~b}$ & NA & Directs flush waste to receiver \\
\hline
\end{tabular}

$\mathrm{NA}=$ Not Applicable, flow to receiver vessel 
The objective of the assembly is to provide feed solutions from the feed lines through the test and guard columns to sample and effluent points.

\subsubsection{Testing in Cold Environment}

Using Figure 1 as a reference for flow streams and Figure 2 as reference for physical layout, the following will be carried out to cold test the system in Building $306 \mathrm{E}$. Care will be taken to try and anticipate problems that may arise during the operation in a hot cell. This will allow a "fix it" mode to be undertaken in a non-radiation area. Figures representing all val ving configurations are provided in Appendix $\mathrm{C}$.

Config. 1: Full System Forward Feed Valving Configuration

(Forward flow to Line 11)

\begin{tabular}{|c|c|c|c||}
\hline Valve & Direction & Valve & Direction \\
\hline \hline $\mathrm{V} 1$ & $\mathrm{~L} 1 \rightarrow \mathrm{V} 1 \rightarrow 1 \mathrm{~A} / \mathrm{B}$ & $\mathrm{V} 8$ & $6 \rightarrow \mathrm{V} 8 \rightarrow 7$ \\
\hline $\mathrm{V} 2 \mathrm{a} / \mathrm{b}$ & $\mathrm{AA} / \mathrm{B} \rightarrow \mathrm{V} 2 \mathrm{a} / \mathrm{b} \rightarrow 2 \mathrm{~A} / \mathrm{B}$ & $\mathrm{V} 9$ & $7 \rightarrow \mathrm{V} 9 \rightarrow \mathrm{C} 2$ \\
\hline $\mathrm{V} 3 \mathrm{a} / \mathrm{b}$ & $2 \mathrm{~A} / \mathrm{B} \rightarrow \mathrm{V} 3 \mathrm{a} / \mathrm{b} \rightarrow 3 \mathrm{~A} / \mathrm{B}$ & $\mathrm{V} 10$ & $\mathrm{C} 2 \rightarrow \mathrm{V} 10 \rightarrow 8$ \\
\hline $\mathrm{V} 4 \mathrm{a} / \mathrm{b}$ & $3 \mathrm{~A} / \mathrm{B} \rightarrow \mathrm{V} 4 \mathrm{a} / \mathrm{b} \rightarrow \mathrm{C} 1 \mathrm{a} / \mathrm{b}$ & $\mathrm{V} 11$ & $8 \rightarrow \mathrm{V} 11 \rightarrow 9$ \\
\hline $\mathrm{V} 5 \mathrm{a} / \mathrm{b}$ & $\mathrm{C} 1 \mathrm{a} / \mathrm{b} \rightarrow \mathrm{V} 5 \mathrm{a} / \mathrm{b} \rightarrow 4 \mathrm{~A} / \mathrm{B}$ & $\mathrm{V} 12$ & $9 \rightarrow \mathrm{V} 12 \rightarrow \mathrm{C} 3$ \\
\hline $\mathrm{V} 6 \mathrm{a} / \mathrm{b}$ & $4 \mathrm{~A} / \mathrm{B} \rightarrow \mathrm{V} 6 \mathrm{a} / \mathrm{b} \rightarrow 5 \mathrm{~A} / \mathrm{B}$ & $\mathrm{V} 13$ & $\mathrm{C} 3 \rightarrow \mathrm{V} 13 \rightarrow 10$ \\
\hline $\mathrm{V} 7$ & $5 \mathrm{~A} / \mathrm{B} \rightarrow \mathrm{V} 7 \rightarrow 6$ & $\mathrm{~V} 14$ & $10 \rightarrow \mathrm{V} 14 \rightarrow 11$ \\
\hline
\end{tabular}

Config. 2: First Guard Column Forward Feed Valving Configuration

(Forward flow to Line 14)

\begin{tabular}{|c|c|c|c||}
\hline Valve & Direction & Valve & Direction \\
\hline $\mathrm{V} 1$ & $\mathrm{~L} 1 \rightarrow \mathrm{V} 1 \rightarrow 1 \mathrm{~A} / \mathrm{B}$ & $\mathrm{V} 7$ & $5 \mathrm{~A} / \mathrm{B} \rightarrow \mathrm{V} 7 \rightarrow 6$ \\
\hline $\mathrm{V} 2 \mathrm{a} / \mathrm{b}$ & $\mathrm{AA} / \mathrm{B} \rightarrow \mathrm{V} 2 \mathrm{a} / \mathrm{b} \rightarrow 2 \mathrm{~A} / \mathrm{B}$ & $\mathrm{V} 8$ & $6 \rightarrow \mathrm{V} 8 \rightarrow 7$ \\
\hline $\mathrm{V} 3 \mathrm{a} / \mathrm{b}$ & $2 \mathrm{~A} / \mathrm{B} \rightarrow \mathrm{V} 3 \mathrm{a} / \mathrm{b} \rightarrow 3 \mathrm{~A} / \mathrm{B}$ & $\mathrm{V} 9$ & $7 \rightarrow \mathrm{V} 9 \rightarrow \mathrm{C} 2$ \\
\hline $\mathrm{V} 4 \mathrm{a} / \mathrm{b}$ & $3 \mathrm{~A} / \mathrm{B} \rightarrow \mathrm{V} 4 \mathrm{a} / \mathrm{b} \rightarrow \mathrm{C} 1 \mathrm{a} / \mathrm{b}$ & $\mathrm{V} 10$ & $\mathrm{C} 2 \rightarrow \mathrm{V} 10 \rightarrow 8$ \\
\hline $\mathrm{V} 5 \mathrm{a} / \mathrm{b}$ & $\mathrm{C} 1 \mathrm{a} / \mathrm{b} \rightarrow \mathrm{V} 5 \mathrm{a} / \mathrm{b} \rightarrow 4 \mathrm{~A} / \mathrm{B}$ & $\mathrm{V} 11$ & $8 \rightarrow \mathrm{V} 11 \rightarrow 14$ \\
\hline $\mathrm{V} 6 \mathrm{a} / \mathrm{b}$ & $4 \mathrm{~A} / \mathrm{B} \rightarrow \mathrm{V} 6 \mathrm{a} / \mathrm{b} \rightarrow 5 \mathrm{~A} / \mathrm{B}$ & & \\
\hline \hline
\end{tabular}


Config. 3: Lead Column Forward Feed Valving Configuration

(Forward flow to Line 13)

\begin{tabular}{|c|c|c|c||}
\hline Valve & Direction & Valve & Direction \\
\hline \hline $\mathrm{V} 1$ & $\mathrm{~L} 1 \rightarrow \mathrm{V} 1 \rightarrow 1 \mathrm{~A} / \mathrm{B}$ & $\mathrm{V} 5 \mathrm{a} / \mathrm{b}$ & $\mathrm{C} 1 \mathrm{a} / \mathrm{b} \rightarrow \mathrm{V} 5 \mathrm{a} / \mathrm{b} \rightarrow 4 \mathrm{~A} / \mathrm{B}$ \\
\hline $\mathrm{V} 2 \mathrm{a} / \mathrm{b}$ & $1 \mathrm{~A} / \mathrm{B} \rightarrow \mathrm{V} 2 \mathrm{a} / \mathrm{b} \rightarrow 2 \mathrm{~A} / \mathrm{B}$ & $\mathrm{V} 6 \mathrm{a} / \mathrm{b}$ & $4 \mathrm{~A} / \mathrm{B} \rightarrow \mathrm{V} 6 \mathrm{a} / \mathrm{b} \rightarrow 5 \mathrm{~A} / \mathrm{B}$ \\
\hline $\mathrm{V} 3 \mathrm{a} / \mathrm{b}$ & $2 \mathrm{~A} / \mathrm{B} \rightarrow \mathrm{V} 3 \mathrm{a} / \mathrm{b} \rightarrow 3 \mathrm{~A} / \mathrm{B}$ & $\mathrm{V} 7$ & $5 \mathrm{~A} / \mathrm{B} \rightarrow \mathrm{V} 7 \rightarrow 6$ \\
\hline $\mathrm{V} 4 \mathrm{a} / \mathrm{b}$ & $3 \mathrm{~A} / \mathrm{B} \rightarrow \mathrm{V} 4 \mathrm{a} / \mathrm{b} \rightarrow \mathrm{Cla} / \mathrm{b}$ & $\mathrm{V} 8$ & $6 \rightarrow \mathrm{V} 8 \rightarrow 13$ \\
\hline
\end{tabular}

Config. 4: CST Pump Flow Rate Calibration Valve Configuration

(Foward flush bypass to Line 12A/B)

\begin{tabular}{|c|c|}
\hline Valve & Direction \\
\hline \hline $\mathrm{V} 1$ & $\mathrm{~L} 1 \rightarrow \mathrm{V} 1 \rightarrow 1 \mathrm{~A} / \mathrm{B}$ \\
\hline $\mathrm{V} 2 \mathrm{a} / \mathrm{b}$ & $1 \mathrm{~A} / \mathrm{B} \rightarrow \mathrm{V} 2 \mathrm{a} / \mathrm{b} \rightarrow 2 \mathrm{~A} / \mathrm{B}$ \\
\hline $\mathrm{V} 3 \mathrm{a} / \mathrm{b}$ & $2 \mathrm{~A} / \mathrm{B} \rightarrow \mathrm{V} 3 \mathrm{a} / \mathrm{b} \rightarrow 12 \mathrm{~A} / \mathrm{B}$ \\
\hline
\end{tabular}

Config. 5: Column Cla/b Reverse Flush Valving Configuration

(Reverse flush to Line 12A/B)

\begin{tabular}{|c|c|c|c||}
\hline \hline Valve & Direction & Valve & Direction \\
\hline \hline $\mathrm{V} 1$ & $\mathrm{~L} 1 \rightarrow \mathrm{V} 1 \rightarrow 1 \mathrm{~A} / \mathrm{B}$ & $\mathrm{V} 5 \mathrm{~A} / \mathrm{B}$ & $4 \mathrm{~A} / \mathrm{B} \rightarrow \mathrm{V} 5 \mathrm{~A} / \mathrm{B} \rightarrow \mathrm{C} 1 \mathrm{~A} / \mathrm{B}$ \\
\hline $\mathrm{V} 2 \mathrm{~A} / \mathrm{B}$ & $1 \mathrm{~A} / \mathrm{B} \rightarrow \mathrm{V} 2 \mathrm{~A} / \mathrm{B} \rightarrow 16 \mathrm{~A} / \mathrm{B}$ & $\mathrm{V} 4 \mathrm{~A} / \mathrm{B}$ & $\mathrm{C} 1 \mathrm{~A} / \mathrm{B} \rightarrow \mathrm{V} 4 \mathrm{~A} / \mathrm{B} \rightarrow 3 \mathrm{~A} / \mathrm{B}$ \\
\hline $\mathrm{V} 6 \mathrm{~A} / \mathrm{B}$ & $16 \mathrm{~A} / \mathrm{B} \rightarrow \mathrm{V} 6 \mathrm{~A} / \mathrm{B} \rightarrow 4 \mathrm{~A} / \mathrm{B}$ & $\mathrm{V} 3 \mathrm{~A} / \mathrm{B}$ & $3 \mathrm{~A} / \mathrm{B} \rightarrow \mathrm{V} 3 \mathrm{~A} / \mathrm{B} \rightarrow 12 \mathrm{~A} / \mathrm{B}$ \\
\hline \hline
\end{tabular}

\subsubsection{Assembly Leak Test}

The CST will not be loaded in the columns for this portion of the test. All test conduct will be recorded via indicated checksheets and datasheets.

Deionized (DI) water will be pumped through the basic assembly for this phase. The connecting lines are the required ID and length and the valving is connected as indicated in Table 2. Use Sheet 3 and place system into various configurations to check for leaks in full forward flow at middle to high set using $\mathrm{Cla}$, and $\mathrm{Clb}$. Images and valving configurations 
Config. 6: Reverse Feed Valving Configuration

HNF-SD-RE-TPI-002, Rev. 0

(Reverse flush through guard columns)

\begin{tabular}{|c|c|c|c|}
\hline Valve & Direction & Valve & Direction \\
\hline \hline $\mathrm{V} 1$ & $\mathrm{~L} 1 \rightarrow \mathrm{V} 1 \rightarrow 1 \mathrm{~B}$ & $\mathrm{~V} 11$ & $9 \rightarrow \mathrm{V} 11 \rightarrow 8$ \\
\hline $\mathrm{V} 2 \mathrm{~b}$ & $1 \mathrm{~B} \rightarrow \mathrm{V} 2 \mathrm{~b} \rightarrow 15$ & $\mathrm{~V} 10$ & $8 \rightarrow \mathrm{V} 10 \rightarrow \mathrm{C} 2$ \\
\hline $\mathrm{V} 14$ & $15 \rightarrow \mathrm{V} 14 \rightarrow 10$ & $\mathrm{~V} 9$ & $\mathrm{C} 2 \rightarrow \mathrm{V} 9 \rightarrow 7$ \\
\hline $\mathrm{V} 13$ & $10 \rightarrow \mathrm{V} 13 \rightarrow \mathrm{C} 3$ & $\mathrm{~V} 8$ & $7 \rightarrow \mathrm{V} 8 \rightarrow 13$ \\
\hline $\mathrm{V} 12$ & $\mathrm{C} 3 \rightarrow \mathrm{V} 12 \rightarrow 9$ & & \\
\hline
\end{tabular}

are provided in Appendix C. The peristaltic pump does not have a digital readout or record. Calibration will be conducted with each flow rate change and recorded on Sheet 3. The flow path for calibration will be Config. 1 .

\subsection{Column Forward Tests}

Use Sheet 5 to record and conduct this procedure.

- Tare receiver bottle $(100 \mathrm{~mL}<$ receiver $<250 \mathrm{~mL})$

- Place L1 into feed vessel T1, place line 11 into tared receiver

- Set valve positions to: Config. 1

- After ensuring the flow path is correct to the above valve settings, turn on the peristaltic pump. For this test, $6 \mathrm{CV} / \mathrm{hr}$ are targeted which is approximately $0.27 \mathrm{~mL} / \mathrm{min}$ or $16.1 \mathrm{~mL} / \mathrm{hr}$. Run in this configuration for 3 hours.

- If leaks are observed, adjust fittings as necessary to eliminate leaks. Record observations and leak repairs.

- After the appropriate time period for leak testing in a forward flow mode, shut down the pump. Record masses collected and time interval on Sheet 3.

\subsection{Column Reverse Flow Tests}

\subsection{Column C1a/C1b Reverse Flow Leak}

Use Sheet 11 to record and conduct this procedure.

- Tare receiver bottle $(\sim 100 \mathrm{~mL})$

- Place line $\mathrm{Ll}$ in feed vessel $\mathrm{T} 1$, place line $12 \mathrm{~A}$ into tared receiver

- Set valve positions to: Config. 5

- After ensuring the flow path is correct to the above valve settings, turn on the peristaltic pump. For this test, $6 \mathrm{CV} / \mathrm{hr}$ are targeted which is approximately $0.27 \mathrm{~mL} / \mathrm{min}$ or $16.1 \mathrm{~mL} / \mathrm{hr}$. Run in this configuration for 1 hour.

- If leaks are observed, adjust fittings as necessary to eliminate leaks. Record observations and leak repairs. 
- After the appropriate time period for leak testing in a reverse flow mode, shut down the pump. Record masses collected and time interval on Sheet 11.

\subsection{Columns C2/C3 Reverse Flush Leak}

Use Sheet 12 to record and conduct this procedure.

- Tare receiver bottle $(\sim 100 \mathrm{~mL})$

- Place line L1 into feed vessel T1, place line 13 into tared receiver

- Set valve positions to: Config. 6

- After ensuring the flow path is correct to the above valve settings, turn on the peristaltic pump. For the CST exchanger, $6 \mathrm{CV} / \mathrm{hr}$ are targeted which is approximately $0.27 \mathrm{~mL} / \mathrm{min}$ or $16.1 \mathrm{~mL} / \mathrm{hr}$. Run in this configuration for 1 hour.

- If leaks are observed, adjust fittings as necessary to eliminate leaks. Record observations and leak repairs.

- After the appropriate time period for leak testing in a reverse flow mode, shut down the pump. Record masses recovered and time interval on Sheet 12.

\subsubsection{Reagent Preparation}

The following reagents shall be prepared by the standards laboratory and delivered to 222-S for hot cell entry:

$\begin{array}{lll}\mathrm{NaOH}, \text { aq. } & 5.0 \underline{\mathrm{M}} & 2.0 \mathrm{~L} \\ \mathrm{HF}, \text { aq. } & 1.0 \underline{\mathrm{M}} & 125 \mathrm{~mL} \\ \mathrm{HCl}, \text { aq. } & 2.0 \underline{\mathrm{M}} & 250 \mathrm{~mL}\end{array}$

Specifications and contaminants of the reagents shall be identified for inclusion in test data analysis.

\subsubsection{Exchange Material Dissolution}

A qualitative evaluation of the dissolution of CST has been carried out in the conduct of test work reported in Hendrickson et al. 1996a. It was found that the CST material substrate and binder dissolved satisfactorily with the addition of hydrochloric and hydrofluoric acids. This dissolution will be repeated in this work. Following contact of wastes with the sorbent, the material will be dissolved within the hot cell using the procedure in Sheet 13.

\subsubsection{Gamma Probe Calibration}

The calibration of the gamma probe will be carried out using 222-S laboratory sources, for a range of $7.4 \mathrm{E} 9 \mathrm{~Bq} / \mathrm{L}$ to $7.4 \mathrm{E} 8 \mathrm{~Bq} / \mathrm{L}\left(0.2 \mathrm{Ci} / \mathrm{L}{ }^{137} \mathrm{Cs}\right.$ to $\left.0.02 \mathrm{Ci} / \mathrm{L}\right)$. The source configuration will be Tygon tubing, $4.76 \mathrm{~mm} \mathrm{ID,} 9.52 \mathrm{~mm} \mathrm{OD}$. The tubing standard should be about $10 \mathrm{~cm}$ in length. The length of the tubing need only be measured approximately, since previous work (Beck et al. 1996) has shown that the gamma detector is sensitive to cesium (barium) gammas only in a small cone $(6 \mathrm{~cm}$ diameter at sample) below the probe. 
An "initial concentration $\left(\mathrm{C}_{0}\right)$ " standard will be made by similarly filling the tubing with feed material. Calibration responses from prepared standards will be entered into a Controlled Laboratory Notebook.

\subsection{TEST PREPARATION AND RUN}

This portion of the test plan is intended to provide explicit instructions and expectations of the conduct of ion exchange with the apparatus using crystalline silicotitanate. The expectations are that the $50 \%$ breakthrough will be at approximately 1500 column volumes $\left(\lambda_{5 i \%}=1500 \mathrm{CV}\right)$. The run is expected to be conducted for up to 2000 column volumes, sampled every 100 column volumes for the first $1000 \mathrm{CV}$ (11 samples) and every $50 \mathrm{CV}$ thereafter (20 samples). Calibrated standards prepared for prior work (Hendrickson et al. 1996a) may be applied with appropriate decay correction.

\subsubsection{Exchange Column Preparation}

Both test columns, $\mathrm{C} 1 \mathrm{a}$ and $\mathrm{C} 1 \mathrm{~b}$, and the guard columns, $\mathrm{C} 2$ and $\mathrm{C} 3$, will be charged with CST and conditioned outside of the hot cell. After conditioning and pump calibration, the columns and system will be transferred into the hot cell. To prepare the CST, manufacturer's specifications will be met with fines removal and sodium hydroxide conditioning. These specifications are not incorporated herein as they are business confidential instructions, but are provided to test personnel.

Use Sheet 14 to prepare and measure the bed density of the sorbent.

Following this conditioning and the following pump calibration, the test assembly will be prepared for hot cell placement.

\subsubsection{CST Apparatus Pump Curve Acquisition}

Because of the varying pressure drops across the apparatus dependent upon sampling location, pump curves will be developed with the loaded columns while feeding $0.220 \underline{\mathrm{M}}$ $\mathrm{NaOH}$. This fluid, used in sorbent conditioning, is also expected to well represent the density and viscosity of waste feed. Following the pump curve acquisition, the flow settings configuration (Config. 4) may be used to ensure adequate flow at the apparatus terminus (line 11).

Use Sheet 3 to record and conduct this procedure

- Tare receiver bottle $(\sim 250 \mathrm{~mL})$

- Place line LI into T3. Place line 11 into tared receiver

- Set valve positions per Sheet 3

Repeat this procedure, for a total of at least three point calibration, at flow settings of approximately $10 \%, 40 \%$, and $60 \%$ of pump knob range. 


\subsubsection{CST Waste Feed Preparation and Analysis}

The waste feed will be composed of a composite of drainable supernatant liquor from samples taken from Hanford Double-Shell tank 241-AN-107 during the 1997 grab sampling operations which are planned for January 1997 (Hohl 1996). The waste feed is of approximately $8.5 \mathrm{M} \mathrm{Na}^{+}$and $0.03 \underline{\mathrm{M} \mathrm{OH}}$. The waste feed will be diluted to a target of approximately $5 \underline{\mathrm{M}} \mathrm{Na}$ with $0.47 \underline{\mathrm{M} \mathrm{NaOH}}$. Analysis of the waste composition for the feed will be carried out by gamma energy analysis, ion chromatography, TIC, TOC, and inductively coupled plasma at $222-\mathrm{S}$, in addition to inductively coupled plasma mass spectrometry conducted on similar samples acquired for privatization (DOE 1996) for speciation of cesium.

It is anticipated that the supernatant liquor will be delivered to the $1 \mathrm{~F}$ Hot Cell in $125 \mathrm{~mL}$ bottles, any undiluted material will remain stoppered. The waste material may be delivered to the hotcell at unspecified times. No time constraint for this work applies with the exception that test run $(\$ 4.2 .5 .5)$ cannot proceed unless the material is prepared.

Use Sheet(s) 4 to record and conduct this procedure. To ensure a homogeneous feed stream throughout the run, the $1 \mathrm{~L}$ batches of prepared feed liquor will be composited in a $3.8 \mathrm{~L}$ vessel. A total of five batches will be prepared in this manner, and the excess over $3.8 \mathrm{~L}$ will be stored in $1 \mathrm{~L}$ bottles. Two feed samples will be withdrawn for analysis, one at the beginning of the test and the second after addition of the feed from the two $1 \mathrm{~L}$ bottles to the $3.8 \mathrm{~L}$ vessel.

\subsubsection{System Flush}

After the system is set up in the hot cell, begin the test by setting pump rates and flushing the system.

Use Sheet 5 to set pump with $0.22 \mathrm{M} \mathrm{NaOH}$ and Sheet 6 to record and conduct the system flush for each lead column.

Set Pump:

Objective: $6 \mathrm{CV} / \mathrm{hr}=16.1 \mathrm{~mL} / \mathrm{hr}$

- Tare receiver bottle $(\sim 100 \mathrm{~mL}$ capacity)

- Place line L1 into T3 (0.22 $\underline{\mathrm{M} \mathrm{NaOH})}$

- Place Line 12A/B into tared receiver

- Set valve positions to: Config. 4. Confirm and record valving alignment.

- Set flow rate - turn on pump, measure for $15 \mathrm{~min}$. Check against objective, record results.

- Reset to get to objective as necessary, repeat.

- When at objective, confirm flow with two more test periods.

- Shut down pump

Flush:

- Place Line 11 into tared receiver

- Place Line L1 into T3 (0.220 $\underline{\mathrm{M}} \mathrm{NaOH})$ 
- Place System Valving in Config. 1 using the first available lead column. Confirm and record valving alignment.

- Turn on pump and run for 2 hours. Record time on/off, flowrate and feed source.

- Close and confirm closure of all valves.

The $0.220 \mathrm{M} \mathrm{NaOH}$ from the conditioning phase $(\$ 4.2 .1)$ will have been flushed through the column and testing for ${ }^{137} \mathrm{Cs}$ removal may begin.

\subsubsection{Cesium Removal Test Run}

Based on modeling of recent CST test results (Hendrickson et al. 1996a) breakthrough $\left({ }^{137} \mathrm{Cs}\right.$ $\mathrm{C} / \mathrm{C}_{0}=0.5$ ) in this test could occur as early as $800 \mathrm{CV}$. Ancillary analyses by CST developers and researchers at Sandia National Laboratory indicate that as many as 1,500 column volumes of this feed may be necessary to achieve $50 \%$ breakthrough. Therefore, this test run will schedule use of $2000 \mathrm{CV}$ to ensure data past breakthrough will be obtained. The test will proceed until $\mathrm{C} / \mathrm{C}_{0} \geq 0.7$ and will be discontinued by direction of the lead engineer or chemist.

\subsubsection{Gamma Detector Data Logging}

During the test run, the gamma detector will be continuously monitoring the effluent line and recording data on an IBM compatible computer using the GammaVision program. The breakthrough of ${ }^{137} \mathrm{Cs}$ will be indicated by the increase in gamma response over time for the window of $\sim 610-680 \mathrm{KeV}$. The detector logging should commence with initial feed startup ( $\$ 4.2 .5 .5)$ and discontinue with final sample acquisition from the flow stream following the test column. Initial estimate for counting periods is $20 \mathrm{~min}$.

The gamma probe must provide an additional function for this component of the test. If the response from the gamma probe indicates $\mathrm{C} / \mathrm{C}_{0}>0.20$ prior to $500 \mathrm{CV}$, the sample regime will accelerate to one sample per $50 \mathrm{CV}$. Sufficient detector shielding will be provided to ensure that cesium loading on columns does not adversely effect detector background. The ganma probe will be read as detailed in Gamma 1 (pg. 16). Detailed instructions for the Gamma probe operation are contained in Appendix D.

\subsubsection{Primary Column Sampling}

All samples will be recorded with column number, date time/group, sample sequence number (C1E-1, C1E-2, ...C1E-n).

It is anticipated that the CST sorbent will be exposed to $2000 \mathrm{CV}$ before the test is stopped. Samples of $5 \mathrm{~mL}$ each will be taken at Line $12 \mathrm{~A}$ (or 12B). At $2000 \mathrm{CV}$ with a flow rate of $6 \mathrm{CV} / \mathrm{h}$, the test will run for 333 hours. The first sample will be taken at 1 hour, representing the effluent stream front. Additional samples will be taken every 16 hours and 40 minutes $(100 \mathrm{CV})$ through $1000 \mathrm{CV}$. Subsequent samples will be taken every 8 hours and 20 minutes $(50 \mathrm{CV})$ through the remainder of the test. Expected samples total 31 and are detailed on Table 3. Should the on-line gamma detector indicate that the cesium $\mathrm{C} / \mathrm{C}_{0}$ 


\section{Reading the Gamma probe:}

The instrument computer (in the 19" instrument rack) should be set up with Notepad ${ }^{\text {un }}$ running.

If Notepad ${ }^{\text {m }}$ is not running, start it by clicking its icon in the Program manager, or AltTAB to switch to Notepad ${ }^{\text {tm }}$

With the Notepad ${ }^{\text {tm }}$ window open, select OPEN from the FILE menu.

Go to the directory C:Ipractjob

Open the highest numbered file that starts with $\operatorname{cs} \#$

It should look like

$$
\text { cs } \# 003 . \mathrm{txt}
$$

with different numbers.

Read the GROSS value. Compare the Gross value with the values posted on the face of the computer or in the notebook. Note the time the file was created (at the top of the file). Record the result on Sheet 8 (if reading during a sampling) and/or on a separately provided data sheet.

If the number is $20 \%$ or greater of the original concentration value, notify the cognizant scientist. Sampling frequency may need to be increased.

If the number is $50 \%$ or greater of the original concentration value, notify the cognizant scientist. The experiment is nearly finished.

\section{Gamma 1: Gamma Probe Reading Procedure}

exceeds $20 \%$, the sample regime shall immediately (nearest $50 \mathrm{CV}$ increment) switch to the accelerated sampling structure of Table 3 . Change procedures of $\$ 5.0$ will be implemented to generate new sampling runtimes in the event of accelerated sampling needs.

Samples shall be acquired as detailed in Table 3. Sampling shall be conducted using Sheet 7 for sample acquisition data and Sheet 8 for process parameters of the sample.

If the system flow rate varies from the target flow by $> \pm 10 \%$, reset the pump through change procedures in $\S 5.0$. It must be recalled that system target flow rates are established as rates of effluent following the guard columns. With the guard columns out of the flow path during sampling, it is expected that flows from the sample point will be slightly higher 
Table 3: CST Test Run Primary Column Sampling

\begin{tabular}{|c|c|}
\hline Sample & Projected Run Time \\
\hline $\mathrm{C} 1 \mathrm{E}-1$ & $1 \mathrm{hr} 0 \mathrm{~min}$ \\
\hline C1E-2 & $17 \mathrm{hr} 40 \mathrm{~min}$ \\
\hline C1E-3 & $34 \mathrm{hr} 20 \mathrm{~min}$ \\
\hline C1E-4 & $51 \mathrm{hr} \quad 0 \mathrm{~min}$ \\
\hline C1E-5 & $67 \mathrm{hr} 40 \mathrm{~min}$ \\
\hline C1E-6 & $84 \mathrm{hr} 20 \mathrm{~min}$ \\
\hline C1E-7 & $101 \mathrm{hr} \quad 0 \mathrm{~min}$ \\
\hline C1E-8 & $117 \mathrm{hr} 40 \mathrm{~min}$ \\
\hline C1E-9 & $134 \mathrm{hr} 20 \mathrm{~min}$ \\
\hline C1E-10 & $151 \mathrm{hr} 0 \mathrm{~min}$ \\
\hline C1E-11 & $167 \mathrm{hr} 40 \mathrm{~min}$ \\
\hline $\mathrm{C} 1 \mathrm{E}-12$ & $176 \mathrm{hr} \quad 0 \mathrm{~min}$ \\
\hline $\mathrm{C} 1 \mathrm{E}-13$ & $184 \mathrm{hr} 20 \mathrm{~min}$ \\
\hline $\mathrm{C} 1 \mathrm{E}-14$ & $192 \mathrm{hr} 40 \mathrm{~min}$ \\
\hline C1E-15 & $201 \mathrm{hr} 0 \mathrm{~min}$ \\
\hline C1E-16 & $209 \mathrm{hr} 20 \mathrm{~min}$ \\
\hline C1E-17 & $217 \mathrm{hr} 40 \mathrm{~min}$ \\
\hline C1E-18 & $226 \mathrm{hr} \quad 0 \mathrm{~min}$ \\
\hline C1E-19 & $234 \mathrm{hr} 20 \mathrm{~min}$ \\
\hline C1E-20 & 242 hr $40 \mathrm{~min}$ \\
\hline $\mathrm{C} 1 \mathrm{E}-21$ & $251 \mathrm{hr} 0 \mathrm{~min}$ \\
\hline C1E-22 & 259 hr 20 min \\
\hline CIE-23 & $267 \mathrm{hr} 40 \mathrm{~min}$ \\
\hline C1E-24 & $276 \mathrm{hr} \quad 0 \mathrm{~min}$ \\
\hline C1E-25 & 284 hr $20 \mathrm{~min}$ \\
\hline C1E-26 & 292 hr $40 \mathrm{~min}$ \\
\hline C1E-27 & $301 \mathrm{hr} \quad 0 \mathrm{~min}$ \\
\hline C1E-28 & 309 hr $20 \mathrm{~min}$ \\
\hline C1E-29 & $317 \mathrm{hr} 40 \mathrm{~min}$ \\
\hline C1E-30 & $326 \mathrm{hr} \quad 0 \mathrm{~min}$ \\
\hline C1E-31 & $334 \mathrm{hr} 20 \mathrm{~min}$ \\
\hline
\end{tabular}

than they would be with the added pressure drop across the guard column. Hence, the pump curves of Sheet 3 are required to appropriately monitor flow.

\subsubsection{Secondary Column Sampling}

All samples will be recorded with column number, date time/group and sample sequence number (C2E-1, C2E-2, ...C2E-n).

It is anticipated that the CST sorbent will be exposed to $2000 \mathrm{CV}$ before the test is stopped. Samples of $5 \mathrm{~mL}$ each will be taken at Valve 11, Line 14. At $2000 \mathrm{CV}$ with a flow rate of 6 $\mathrm{CV} / \mathrm{h}$, the test will run for 333 hours. The first sample will be taken at 17 hours and 10 minutes. Additional samples will be taken every 33 hours and 20 minutes $(200 \mathrm{CV})$ until test completion.

Samples shall be acquired as detailed in Table 4 . 
Table 4: CST Test Run Secondary Column Sampling

\begin{tabular}{||l|l|}
\hline \hline Sample & Projected Run Time \\
\hline C2E-1 & $17 \mathrm{hr} 10 \mathrm{~min}$ \\
\hline C2E-2 & $50 \mathrm{hr} 30 \mathrm{~min}$ \\
\hline C2E-3 & $83 \mathrm{hr} 50 \mathrm{~min}$ \\
\hline C2E-4 & $117 \mathrm{hr} 10 \mathrm{~min}$ \\
\hline C2E-5 & $150 \mathrm{hr} 30 \mathrm{~min}$ \\
\hline C2E-6 & $183 \mathrm{hr} 50 \mathrm{~min}$ \\
\hline C2E-7 & $217 \mathrm{hr} 10 \mathrm{~min}$ \\
\hline C2E-8 & $250 \mathrm{hr} 30 \mathrm{~min}$ \\
\hline C2E-9 & $283 \mathrm{hr} 50 \mathrm{~min}$ \\
\hline C2E-10 & $317 \mathrm{hr} 10 \mathrm{~min}$ \\
\hline
\end{tabular}

Sampling shall be conducted using Sheet 9 for sample acquisition data and Sheet 10 for process parameters of the sample.

\subsubsection{System Effluent Sampling}

The sampling from the second guard column (C3) will be of composite materials. At test initiation place a $1 \mathrm{~L}$ container under V14/11. This volume should be sufficient for approximately 60 hours of operation. Replace this container when it has reached $75 \%$ of capacity or will do so by the next sampling effort. At the end of the run, take an aliquot of approximately $5 \mathrm{~mL}$ from each container. Identify the samples as C3E-1 to C3E-n, where $n$ is the container number (should not exceed 6).

\subsubsection{Run Execution}

Use Sheet 6 to record and conduct this procedure

Confirm or do:

Objective: $6 \mathrm{CV} / \mathrm{hr}=16.1 \mathrm{~mL} / \mathrm{hr}$

- Tare receiver bottle (1L)

- Place Line 11 into $1 \mathrm{~L}$ collection vessel

- Place line L1 into T2 (Waste Feed)

- Confirm valving for Config. 1. Confirm and record valving alignment on Sheet 6.

- Measure and record feed temperature $\left({ }^{\circ} \mathrm{C}\right)$

- Turn on pump and initiate test runtime clock. Record test initiation on Sheet 6.

- Acquire data and samples as directed above.

- Continue flow until $\gamma$ probe response is beyond $-70 \% \mathrm{C} / \mathrm{C}_{0}$.

- Immediately following last primary column sample, shut down pump, and take the composite effluent samples from the receivers filled below V14/11.

- Close and confirm closure of all valves. 


\subsubsection{System Flush}

After the feed solution has run through the system, the system will be flushed with $0.220 \underline{\mathrm{M}}$ $\mathrm{NaOH}$ for $15 \mathrm{CV}$ at $6 \mathrm{CV} / \mathrm{h}(2.5$ hours $)$. Allow the flush to run to the flush receiver.

Use Sheet 6 to record and conduct this procedure.

- Wash exterior of Line L1 with $\mathrm{H}_{2} \mathrm{O}$, place L1 in T3 $(0.220 \underline{\mathrm{M}} \mathrm{NaOH})$

- Place 11 into flush waste receiver (1L)

- Establish valving for Config. 1. Confirm and record valving alignment.

- Turn on pump for 2.5 hours. Record start time.

- Turn off pump. Record stop time

- Close and confirm closure of all valves.

No samples will be taken of this waste.

\subsection{SYSTEM CLEANOUT AND WASTE MANAGEMENT}

The application of this section is to minimize the volume and form of waste to be disposed from the hot cells. Wastes shall be handled in accordance with WAC 173-303 (Ecology 1994).

\subsubsection{Thermolabile Wastes}

All poly tubing, thermoplastics, etc. that will melt are to be placed in a metal container. The container will then be placed on a hot plate and the material melted in accordance with appropriate procedure (LO-100-106, Marshall 1994), the can cooled and sealed and disposed in accordance with WAC 173-303. (WDOE 1994)

\subsubsection{Sorbent Columns}

When the test is completed, use Sheet 13 for instructions and record of removal of spent sorbent from all the columns, followed by dissolution and disposal. No samples will be taken because digested sample analysis results for the last test were not usable. All columns should be dissolved together in one batch.

Dissolved exchange material solutions are to be poured down the hot cell drain.

DURING THE TEST RUN, ALL SAMPLE POINTS (LINES 12A/B, 13, 14, 11) WILL HAVE A CATCH CONTAINER TO CONTAIN SPILLS. 


\subsubsection{Other Liquors}

Effluent materials from test conduct, acquired at line 11, are to be retained, in separate, labeled, 1 liter bottles. These materials will be shipped to PNNL for additional anionic exchange studies.

Waste flushes and washes are to be poured down the hot cell drain. Unanalyzed samples, unless otherwise specified at test close out, are to be poured down the hot cell drain. Unused diluted waste feed, unless otherwise specified at test close out, are to be poured down the hot cell drain. Unused and undiluted waste feed is to be returned to archive.

\subsubsection{Other Solid Wastes}

Other solid wastes will include the glass exchange columns, valves, fittings, and glassware for material handling. This material should be triple rinsed and packaged for disposal. Pour rirse liquors down hot cell drain.

\subsection{SAMPLING AND SAMPLE ANALYSES}

Analytical sample selection for analyses of feed wastes, effluents, digest, and eluates are presented in Table 5. Rubidium, potassium, strontium, and cesium isotopic analyses are to be conducted by inductively coupled plasma mass spectroscopy (ICP-MS); hydroxide by potentiometric titration or specific ion electrode, other metals $(\mathrm{Na}, \mathrm{Al}, \mathrm{K}, \mathrm{Cr}, \mathrm{Fe}, \mathrm{P})$ are to by analyzed by inductively coupled plasma atomic emission spectroscopy (ICP-AES), transuranic metals ( $\mathrm{Am}, \mathrm{Pu}, \mathrm{Np}$ ) are to be analyzed by alpha emission analysis (AEA), and ${ }^{137} \mathrm{Cs}$ and ${ }^{134} \mathrm{Cs}$ by gamma energy analysis (GEA). Selected waste feeds and effluents will be analyzed for total organic carbon by TOC, total inorganic carbon, and for nitrate, nitrite, fluoride, chloride, and sulfate by ion chromatography. Test conduct will include on-line gamma analysis.

\begin{tabular}{|c|c|c|c|c|c|c|c|c|c|c|c|}
\hline \multirow{2}{*}{ Salmple } & Method & \multirow{2}{*}{ ICP-MS } & \multirow{2}{*}{ ICP-AES } & \multirow{2}{*}{$\mathrm{GEA}$} & \multirow{2}{*}{ AEA } & \multirow{2}{*}{ IC } & \multirow{2}{*}{ TIC } & \multirow{2}{*}{ TOC } & \multirow{2}{*}{$\mathrm{OH}-$} & \multirow{2}{*}{ Density } & \multirow{2}{*}{ On-line $\gamma$} \\
\hline & Description & & & & & & & & & & \\
\hline Core-1 & Tank Liquor & $\mathrm{X}$ & $\mathrm{X}$ & $\mathrm{X}$ & & $X$ & & & & & \\
\hline Core-2 & Tank Liquor & $\mathrm{X}$ & $x$ & $\mathrm{X}$ & & $\mathrm{X}$ & & & & & \\
\hline$\Gamma 1$ & Waste Feed & & $\mathrm{X}$ & $\mathrm{X}$ & $\mathrm{X}$ & $\mathrm{x}$ & $\mathrm{X}$ & $\mathrm{X}$ & $X$ & & \\
\hline $\mathrm{F} 2$ & Waste Feed & & $\mathrm{X}$ & $\mathrm{X}$ & $\mathrm{X}$ & $x$ & $\mathrm{X}$ & $\mathrm{X}$ & $X$ & & \\
\hline FSI & Centrifuge slds & & $\mathrm{X}$ & $\mathrm{X}$ & $\mathrm{x}$ & & & & & & \\
\hline $\mathrm{FS} 2$ & Centrifuge sids & & $\mathrm{X}$ & $\mathrm{X}$ & $\mathrm{X}$ & & & & & & \\
\hline $\mathrm{C} 1 \mathrm{E}-1$ & C1a/b Effluent & & $\mathrm{X}$ & $\mathrm{X}$ & & & & & & & $\mathrm{X}$ \\
\hline $\mathrm{C} 1 \mathrm{E}-2$ & Cla/b Effluent & & $\mathrm{X}$ & $\mathrm{X}$ & & & & & & & $\mathrm{X}$ \\
\hline CIE-3 & C1a/b Effluent & & $x$ & $\mathrm{x}$ & & $\mathrm{X}$ & $\mathrm{X}$ & & $X$ & & $x$ \\
\hline $\mathrm{CIE}-4$ & Cla/b Eftluent & & $\mathrm{X}$ & $\mathrm{X}$ & & & & & & & $\mathrm{X}$ \\
\hline $\mathrm{C} 1 \mathrm{E}-5$ & C1a/b Effluent & & $\mathrm{X}$ & $x$ & & & & & & & $\mathrm{X}$ \\
\hline $\mathrm{C} 1 \mathrm{E}-6$ & C1a/b Effluent & & $\mathrm{X}$ & $x$ & & & & & & & $\mathrm{X}$ \\
\hline C15.7 & $\mathrm{C} 1 \mathrm{a} / \mathrm{b}$ Effluent & & $\mathrm{X}$ & $\mathrm{X}$ & & $X$ & $\mathrm{X}$ & & $\mathrm{X}$ & & $\mathrm{X}$ \\
\hline
\end{tabular}


HNF-SD-RE-TPI-002, Rev. 0

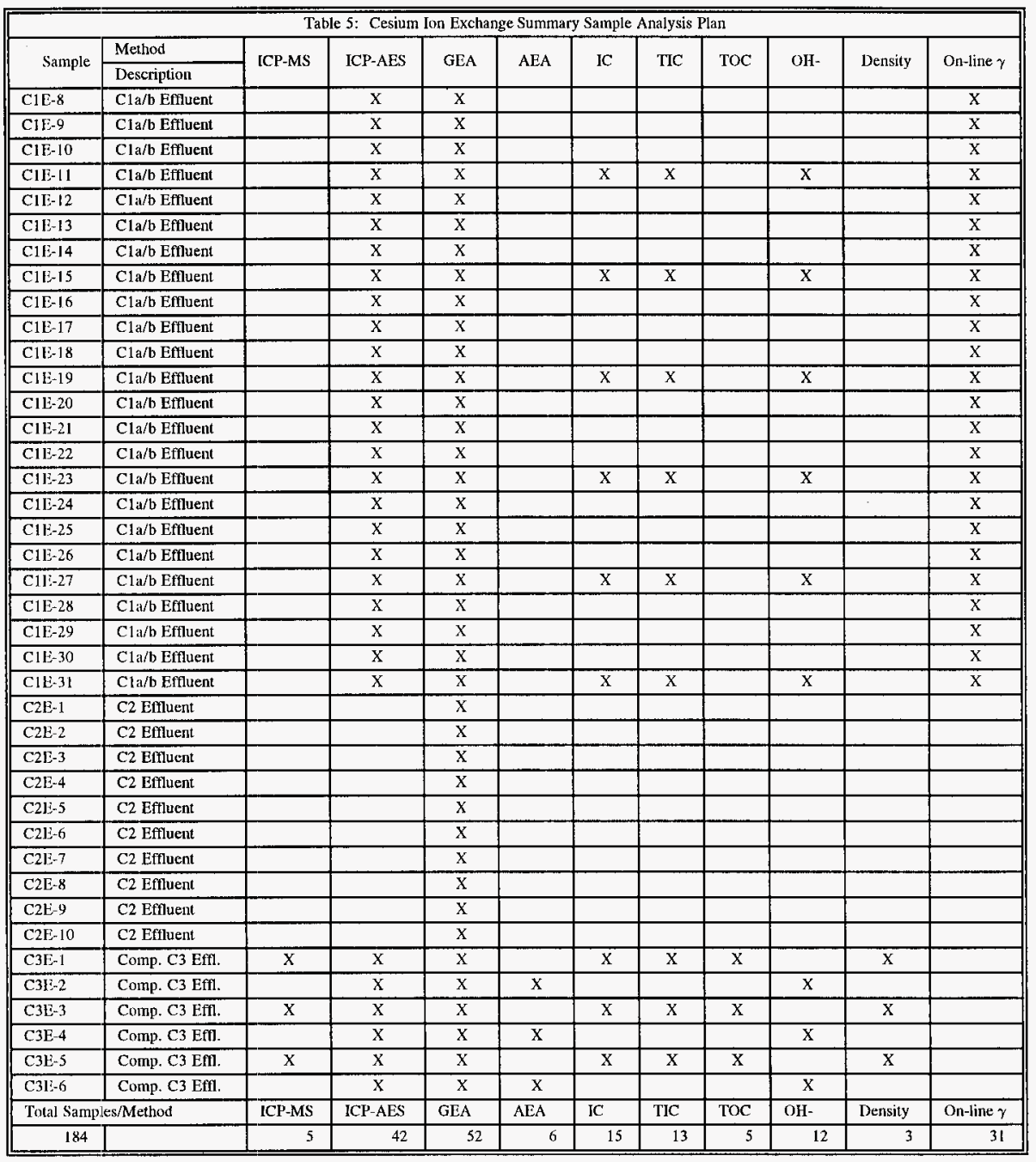




\subsection{CHANGE PROCEDURE}

\subsection{General Changes}

As in any experimental test conduct, the possibility of procedural revision exists. Operating personnel may institute any necessary changes with approval of the lead engineer or scientist. Such change will be documented in an engineering change notice at test completion for configuration control where necessary. All changes will be recorded in the laboratory notebook and reported with test results.

\subsection{Sampling Frequency Change}

Due to the potential of early breakthrough of analytes of interest (i.e. ${ }^{137} \mathrm{Cs}$ ) in test columns, the on-line $\gamma$ detector will be operated to report effluent activities. Should the activity exceed $20 \%$ of breakthrough prior to sampling frequency shift stated in sampling section 4.2.5.5, the operating personnel should contact the lead engineer or scientist and institute a sampling frequency shift as directed. That shift must be defined in terms of run time (i.e. flow volume). Such change will be recorded in the laboratory notebook and reported with tests results.

\subsection{Pump Flow Rate Reset}

Due to the potential of pump flow rate drift through tubing crimping, exchange material degradation, or other causes, the test apparatus flow may depart from the test objective rate. Should the observed rate under $\S 4.2 .5 .5$, deviate from the object by greater than $10 \%$, the pump rate should be reset to the appropriate rate through procedures on Sheet 5 . The operating personnel may institute the required change with approval of the lead engineer or chemist. Such change will be recorded in the laboratory notebook.

\subsection{QUALITY ASSURANCE}

Quality assurance requirements are guided by 10 CFR 830.120 Quality Assurance Requirements (DOE 1994a) and by the Implementation Guide for Use with 10 CFR 830.120 (DOE 1994b). The implementation of 10 CFR 830.120 is through the Quality Assurance Manual (WHC 1996) and facility specific quality assurance plans.

Existent quality assurance requirements encompassed by the Quality Assurance Plan (Meznarich 1995) of the laboratory facilities will be met in the conduct of this work and its chemical analyses. The quality assurance for the conduct of the unit operations and hot cell activities will be in accordance with the approved process testing quality assurance plan (Meznarich 1996). 


\subsection{REFERENCES}

Beck, M. A., R. S. Addleman, G. R. Blewitt, E. R. Selle, C. S. McClellan, D. A. Dodd, G. L. Troyer, and B. D. Keele, 1996, Remote Nuclear Screening System for Hostile Environments, WHC-SD-WM-DTR-024, Rev. 0, Westinghouse Hanford Company, Richland, Washington, February 27, 1996.

Hohl, T. M., 1996, Grab Sampling and Analysis Plan for Tank 241-AN-107 (in support of the Hanford CC Supernatant Cesium Removal Test), WHC-SD-WM-TSAP-120, Rev. 0, SGN Eurisys Services Corporation, Richland, Washington, December 30, 1996.

DOE, 1994a, Nuclear Safety Management, "Quality Assurance Requirements," 10 CFR 830.120, U. S. Department of Energy, Washington D.C., April 5, 1994.

DOE, 1994b, Implementation Guide for Use with 10 CFR 830.120 Quality Assurance, G-830.120-Rev. 0, U. S. Department of Energy, Washington D.C., April 15, 1994.

EF'A, 1986, 40 CFR \$261.31, Hazardous wastes from non-specific sources, U. S. Environmental Protection Agency, Washington, D.C., August 25, 1986.

Hendrickson, D. W., R. K. Biyani, and M. A. Beck, 1996a, Hanford Tank Waste Supernatant Cesium Removal Test Report, WHC-SD-RE-TRP-018, Rev. 0A, Westinghouse Hanford Company, Richland, Washington, October 1996.

Hendrickson, D. W., R. K. Biyani, and J. B. Duncan, 1996b, Hanford Complexant Concentrate Supernatant Cesium Removal Test Plan, WHC-SD-RE-TP-023, Rev. 0, Westinghouse Hanford Company, Richland, Washington, November 1996.

Marshall, R. P., 1994, Melting Plastic Material in Cubicles of the 222-S Laboratory, LO-100-106, Westinghouse Hanford Company, Richland, Washington, March 1994.

Meznarich, H. K., 1995, 222-S Laboratory Quality Assurance Plan, WHC-SD-CP-QAPP-016, Rev. 0, Westinghouse Hanford Company, Richland, Washington, July 31, 1995.

Meznarich, H. K., 1996, 222-S Process and Development Laboratory Quality Assurance Plan, WHC-SD-CP-QAPP-018, Rev. 0, Westinghouse Hanford Company, Richland, Washington, June 1996.

Perry, R. H., D. W. Green, J. O. Maloney, Perry's Chemical Engineer's Handbook, Sixth Edition, McGraw-Hill Book Company, New York, New York, 1984.

WDOE, 1994, Washington Administrative Code, Chapter 173-303, Dangerous Waste Regulations, (WAC 173-303), Washington Department of Ecology, Olympia, Washington, January 8, 1994. 
HNF-SD-RE-TPI-002, Rev. 0

Appendix A: Checksheets and Data Sheets 
HNF-SD-RE-TPI-002, Rev. 0

THIS PAGE INTENTIONALLY LEFT BLANK

A-ii 


\section{LIST OF CHECKSHEETS AND DATASHEETS}

1: Feed System Assembly . . . . . . . . . . . . . . . . . A A-1

2: Test Assembly Instructions and Checksheet $\ldots \ldots \ldots \ldots \ldots \ldots \ldots$ A-3

3: Pump Calibration for the CST Column Test . . . . . . . . . . . . . . A A-4

4: Waste Feed Preparation . . . . . . . . . . . . . . . . . A-7

5: Pump Flow Rate Set and Measurement . . . . . . . . . . . . . . . . . A-8

6: Effluent Collection Record . . . . . . . . . . . . . . . . . . . A A-9

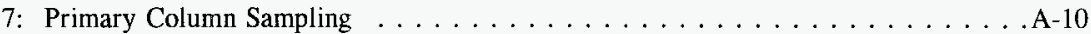

8: Primary Column Sample Record . . . . . . . . . . . . . . . . . A-11

9: Secondary (C2) Column Sampling . . . . . . . . . . . . . . . . . . A-13

10: Secondary (C2) Column Sample Record . . . . . . . . . . . . . . . . A-14

11: Primary Column Cla/b Reverse Feed Valving . . . . . . . . . . . A-15

12: Guard Columns $\mathrm{C} 2$ \& C3 Reverse Feed Valving . . . . . . . . . . . A-16

13: CST Sorbent Dissolution . . . . . . . . . . . . . . . . . A A-17

14: CST Sorbent Bed Density Determination . . . . . . . . . . . . . A-18

15: $\mathrm{NaOH}$ Solution Preparation from 5.0 mole/L Stock . . . . . . . . . . . . A-20 
HNF-SD-RE-TPI-002, Rev. 0

THIS PAGE INTENTIONALLY LEFT BLANK

A-iv 


\section{Sheet 1: Feed System Assembly}

See Figure A-1 and Figure A-2:

Checksheet\#

Assemble Line L1 as composite of $1.5 \mathrm{~m}$ Tygon tubing, $0.51 \mathrm{~mm}$ ID, fitted to $10 \mathrm{~cm}$ Tygon tubing, $3.175 \mathrm{~mm}$ ID. Connect $3.175 \mathrm{~mm}$ ID end of L1 to Valve V1. Mount $0.51 \mathrm{~mm}$ ID segment of L1 through pump head.

Next, to ensure that the feed line is situated about $1 "$ above the bottom of the feed container, assemble a dip tube for the feed line as follows. Drill a $1 / 4$ " hole and a $1 / 8$ " vent hole in a No. 6 rubber stopper (suitable for the $3.8 \mathrm{~L}$ feed container). Position a $151 / 2$ " long $\mathrm{x} 1 / 4$ " diameter glass tube through the rubber stopper so that the end of the glass tube is 1 " above the bottom of the feed container. For support, attach a piece of tape (as a flag) on the $0.51 \mathrm{~mm}$ feed line $15 "$ from the free end and insert the tubing through the glass dip tube.

Assembly confirmed:

Date:

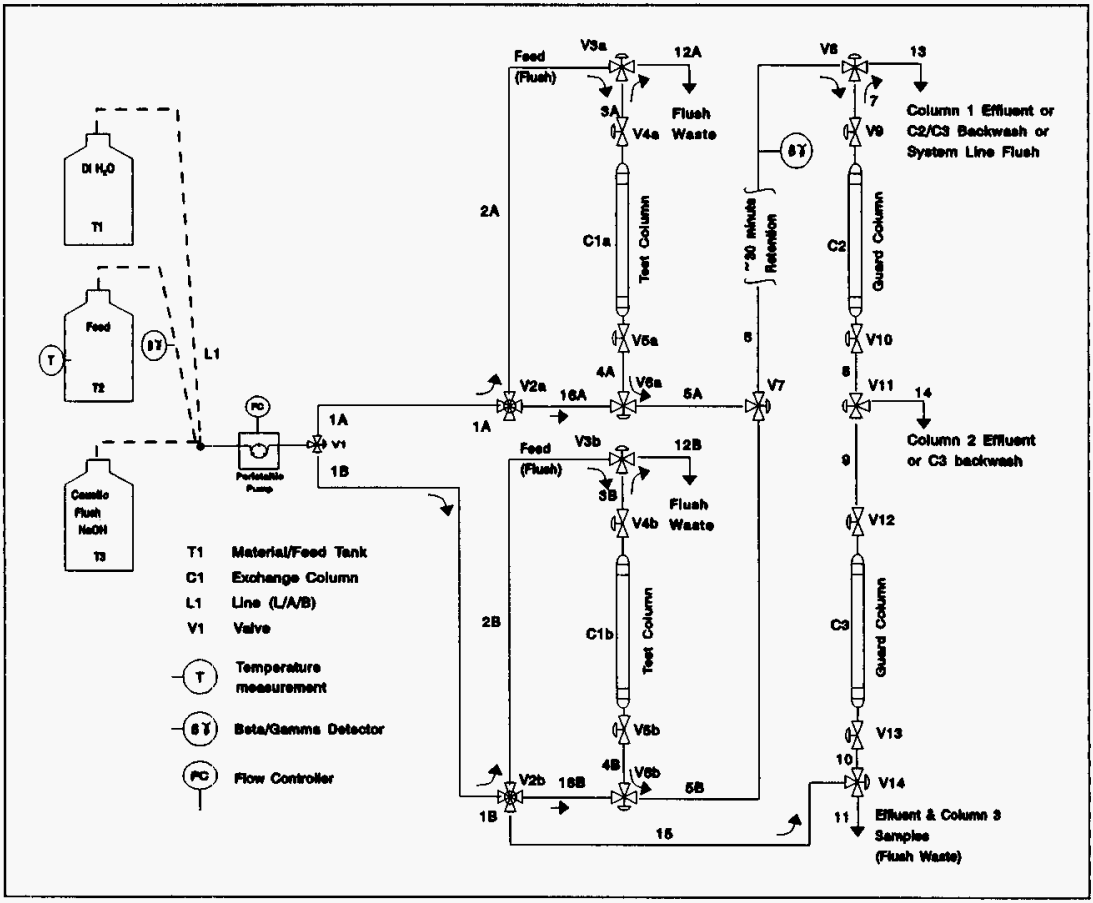

Figure A-1: Bench-Scale Cesium Exchange Flows and Instrumentation 
Sheet 1: Feed System Assembly - Continued

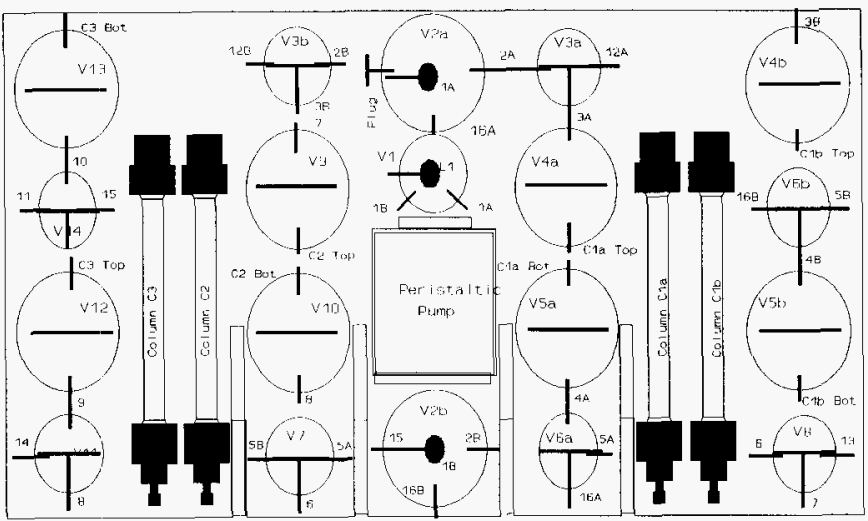

Figure A-2: Physical Test Assembly Valve and Column Arrangement 
Sheet 2: Test Assembly Instructions and Checksheet

Checksheet\#

Mount valves and columns in test assembly (See Figure A-1 for flow intent, Figure A-2 for layout).

Connect line $1 \mathrm{~A}\left(3.2 \mathrm{~mm}\right.$ ID, $\left.20 \mathrm{~cm} \mathrm{Tygon}{ }^{3}\right)$ to $\mathrm{V} 1$ and $\mathrm{V} 2 \mathrm{a}$.

Connect line 1B (3.2 $\mathrm{mm}$ ID, $39 \mathrm{~cm}$ Tygon) to V1 and V2b.

Connect line 2A (3.2 mm ID, $7 \mathrm{~cm}$ Tygon) to $\mathrm{V} 2 \mathrm{a}$ and $\mathrm{V} 3 \mathrm{a}$.

Connect line 2B (3.2 $\mathrm{mm}$ ID, $44 \mathrm{~cm}$ Tygon) to V2b and V3b.

Connect line $3 \mathrm{~A}$ ( $3.2 \mathrm{~mm}$ ID, $5 \mathrm{~cm}$ Tygon) to V3a and V4a.

Connect line 3B (3.2 mm ID, $43 \mathrm{~cm}$ Tygon) to V3b and V4b.

Connect line (Composite ${ }^{*}$ ) to V4a and Cla (top).

Connect line (Composite ${ }^{*}$ ) to $\mathrm{V} 4 \mathrm{~b}$ and $\mathrm{C} 1 \mathrm{~b}$ (top).

Connect line (Composite*) to Cla (bottom) and V5a.

Connect line (Composite*) to V5b and Clb (bottom).

Connect line 4A (3.2 mm ID, $5 \mathrm{~cm}$ Tygon) to V5a and V6a.

Connect line 4B (3.2 $\mathrm{mm}$ ID, $5 \mathrm{~cm}$ Tygon) to V5b and V6b.

Connect line 5A (3.2 $\mathrm{mm}$ ID, $28 \mathrm{~cm}$ Tygon) to V6a and V7.

Connect line $5 \mathrm{~B}(3.2 \mathrm{~mm} \mathrm{ID,} 71 \mathrm{~cm}$ Tygon) to V6b and V7.

Connect line 6 (V7 to the following composite: $3.2 \mathrm{~mm}$ ID, $2 \mathrm{~cm}$ Tygon joined to $4.8 \mathrm{~mm}$

ID, $60 \mathrm{~cm}$ Tygon joined to $3.2 \mathrm{~mm}$ ID, $25 \mathrm{~cm}$ Tygon to V8).

Connect line $7(3.2 \mathrm{~mm}$ ID, $71 \mathrm{~cm}$ Tygon) to $\mathrm{V} 8$ and $\mathrm{V} 9$.

Connect line (Composite) to V9 and C2 (top).

Connect line (Composite") to V10 and C2 (bottom).

Connect line 8 (3.2 mm ID, $32 \mathrm{~cm}$ Tygon) to V10 and V11.

Connect line 9 (3.2 mm ID, $5 \mathrm{~cm}$ Tygon) to V11 and V12.

Connect line (Composite*) to V12 and C3 (top).

Connect line (Composite*) to V13 and C3 (bottom).

Connect line 10 (3.2 mm ID, $5 \mathrm{~cm}$ Tygon) to V13 and V14.

Connect line 15 (3.2 mm ID, $36 \mathrm{~cm}$ Tygon) to $\mathrm{V} 2 \mathrm{~b}$ and $\mathrm{V} 14$.

Connect line 12A (3.2 mm ID, $60 \mathrm{~cm}$ Tygon) to V3a.

Connect line 13 (3.2 $\mathrm{mm}$ ID, $25 \mathrm{~cm}$ Tygon) to V8

Connect line 14 (3.2 $\mathrm{mm}$ ID, $25 \mathrm{~cm}$ Tygon) to V11.

Connect line 11 (3.2 $\mathrm{mm}$ ID, $35 \mathrm{~cm}$ Tygon) to V14.

Connect line 12B (3.2 mm ID, $60 \mathrm{~cm}$ Tygon) to V $3 \mathrm{~b}$.

Connect line 16A (3.2 mm ID, $35 \mathrm{~cm}$ Tygon) to V2a and V6a.

Connect line 16A (3.2 mm ID, $35 \mathrm{~cm}$ Tygon) to V2a and V6a.

Composite $^{*}=(3.2 \mathrm{~mm}$ ID, $2 \mathrm{~cm}$ Tygon, $3.2 \mathrm{~mm} \times 1.6 \mathrm{~mm}$ polypropylene connector, $1.6 \mathrm{~mm}$ ID, $2 \mathrm{~cm}$ Tygon, $1.6 \mathrm{~mm}$ ID, $79 \mathrm{~cm}$ Teflon).

Assembly confirmed (init.): Date:

Tygon is a trademark of Norton Performance Plastics, Akron, $\mathrm{OH}$. 
Sheet 3: Pump Calibration for the CST Column Test

Objective: To compare the pump flow rate at different locations in the test apparatus. The flow rate at $12 \mathrm{~A}$ will be plotted against effluent flow rates at lines 13,14 , and 11 . This will be repeated for the flow at $12 \mathrm{~B}$ and lines 13,14 , and 11 using $0.22 \mathrm{M} \mathrm{NaOH}$.

Begin by adjusting the pump dial to achieve the target flow rate of $0.27 \mathrm{~mL} / \mathrm{min}$ at line 11 . Follow the steps below to measure the flow rate. When this desired flow rate is reached, inscribe a mark on the pump dial and record approximate radial setting. This procedure will be carried out for two pump settings in the vicinity of the target. Turn pump knob counterclockwise half distance to zero flow, and repeat flow rate measurement. Then turn the pump knob clockwise until the same distance to the right of the inscribed set point is reached.

Executed for Test Procedure Step: 4.2.2 Checksheet\#

Executed by (print name):

Run Start (Date/time): Completed Date/time:

Prior to carrying out the procedure:

A. Place an empty $100 \mathrm{~mL}$ beaker on an analytical top loading balance for ease of continual weight measurements. With the aid of a laboratory stand secure discharge lines $12 \mathrm{~A}, 12 \mathrm{~B}, 13,14$, and 11 above this tared receiver.

B. Place line $\mathrm{L} 1$ into a feed bottle containing $300 \mathrm{~mL}$ of $0.22 \underline{\mathrm{M} \mathrm{NaOH}}$.

C. Set valve positions per Configuration 1, for Cla; all other valves shall remain closed.

D. Adjust the pump knob setting to an approximate $30^{\circ}$ radial position from zero. Once the system has been charged with the caustic solution, begin the test procedure.

\section{Test Procedure:}

1. Turn on pump for 20 minutes; use a stop watch.

2. Turn pump off, record time of flow, weigh the receiver.

3. Record all data in the table below.

4. With the same pump setting take flow rate measurements with valves positioned per Config. $2,3 \& 4$.

5. Repeat steps B thru 4 for valves positioned for flow through backup column Clb. 
Sheet 3: Pump Calibration for the CST Column Test - Continued Config.1: Full System Forward Feed Valving Configuration (Forward flow to Line 11)

\begin{tabular}{|c|c|c|c||}
\hline Valve & Direction & Valve & Direction \\
\hline $\mathrm{V} 1$ & $\mathrm{~L} 1 \rightarrow \mathrm{V} 1 \rightarrow 1 \mathrm{~A} / \mathrm{B}$ & $\mathrm{V} 8$ & $6 \rightarrow \mathrm{V} 8 \rightarrow 7$ \\
\hline $\mathrm{V} 2 \mathrm{a} / \mathrm{b}$ & $1 \mathrm{~A} / \mathrm{B} \rightarrow \mathrm{V} 2 \mathrm{a} / \mathrm{b} \rightarrow 2 \mathrm{~A} / \mathrm{B}$ & $\mathrm{V} 9$ & $7 \rightarrow \mathrm{V} 9 \rightarrow \mathrm{C} 2$ \\
\hline $\mathrm{V} 3 \mathrm{a} / \mathrm{b}$ & $2 \mathrm{~A} / \mathrm{B} \rightarrow \mathrm{V} 3 \mathrm{a} / \mathrm{b} \rightarrow 3 \mathrm{~A} / \mathrm{B}$ & $\mathrm{V} 10$ & $\mathrm{C} 2 \rightarrow \mathrm{V} 10 \rightarrow 8$ \\
\hline $\mathrm{V} 4 \mathrm{a} / \mathrm{b}$ & $3 \mathrm{~A} / \mathrm{B} \rightarrow \mathrm{V} 4 \mathrm{a} / \mathrm{b} \rightarrow \mathrm{C} 1 \mathrm{a} / \mathrm{b}$ & $\mathrm{V} 11$ & $8 \rightarrow \mathrm{V} 11 \rightarrow 9$ \\
\hline $\mathrm{V} 5 \mathrm{a} / \mathrm{b}$ & $\mathrm{C} 1 \mathrm{a} / \mathrm{b} \rightarrow \mathrm{V} 5 \mathrm{a} / \mathrm{b} \rightarrow 4 \mathrm{~A} / \mathrm{B}$ & $\mathrm{V} 12$ & $9 \rightarrow \mathrm{V} 12 \rightarrow \mathrm{C} 3$ \\
\hline $\mathrm{V} 6 \mathrm{a} / \mathrm{b}$ & $4 \mathrm{~A} / \mathrm{B} \rightarrow \mathrm{V} 6 \mathrm{a} / \mathrm{b} \rightarrow 5 \mathrm{~A} / \mathrm{B}$ & $\mathrm{V} 13$ & $\mathrm{C} 3 \rightarrow \mathrm{V} 13 \rightarrow 10$ \\
\hline $\mathrm{V} 7$ & $5 \mathrm{~A} / \mathrm{B} \rightarrow \mathrm{V} 7 \rightarrow 6$ & $\mathrm{~V} 14$ & $10 \rightarrow \mathrm{V} 14 \rightarrow 11$ \\
\hline \hline
\end{tabular}

Config. 2: First Guard Column Forward Feed Valving Configuration (Forward Flow to Line 14)

\begin{tabular}{|c|c|c|c|}
\hline Valve & Direction & Valve & Direction \\
\hline \hline $\mathrm{V} 1$ & $\mathrm{~L} 1 \rightarrow \mathrm{V} 1 \rightarrow 1 \mathrm{~A} / \mathrm{B}$ & $\mathrm{V} 7$ & $5 \mathrm{~A} / \mathrm{B} \rightarrow \mathrm{V} 7 \rightarrow 6$ \\
\hline $\mathrm{V} 2 \mathrm{a} / \mathrm{b}$ & $1 \mathrm{~A} / \mathrm{B} \rightarrow \mathrm{V} 2 \mathrm{a} / \mathrm{b} \rightarrow 2 \mathrm{~A} / \mathrm{B}$ & $\mathrm{V} 8$ & $6 \rightarrow \mathrm{V} 8 \rightarrow 7$ \\
\hline $\mathrm{V} 3 \mathrm{a} / \mathrm{b}$ & $2 \mathrm{~A} / \mathrm{B} \rightarrow \mathrm{V} 3 \mathrm{a} / \mathrm{b} \rightarrow 3 \mathrm{~A} / \mathrm{B}$ & $\mathrm{V} 9$ & $7 \rightarrow \mathrm{V} 9 \rightarrow \mathrm{C} 2$ \\
\hline $\mathrm{V} 4 \mathrm{a} / \mathrm{b}$ & $3 \mathrm{~A} / \mathrm{B} \rightarrow \mathrm{V} 4 \mathrm{a} / \mathrm{b} \rightarrow \mathrm{C} 1 \mathrm{a} / \mathrm{b}$ & $\mathrm{V} 10$ & $\mathrm{C} 2 \rightarrow \mathrm{V} 10 \rightarrow 8$ \\
\hline $\mathrm{V} 5 \mathrm{a} / \mathrm{b}$ & $\mathrm{C} 1 \mathrm{a} / \mathrm{b} \rightarrow \mathrm{V} 5 \mathrm{a} / \mathrm{b} \rightarrow 4 \mathrm{~A} / \mathrm{B}$ & $\mathrm{V} 11$ & $8 \rightarrow \mathrm{V} 11 \rightarrow 14$ \\
\hline $\mathrm{V} 6 \mathrm{a} / \mathrm{b}$ & $4 \mathrm{~A} / \mathrm{B} \rightarrow \mathrm{V} 6 \mathrm{a} / \mathrm{b} \rightarrow 5 \mathrm{~A} / \mathrm{B}$ & & \\
\hline
\end{tabular}

Config, 3: Lead Column Forward Feed Valving Configuration (Forward Flow to Line 13)

\begin{tabular}{|c|c|c|c|}
\hline Valve & Direction & Valve & Direction \\
\hline $\mathrm{V} 1$ & $\mathrm{~L} 1 \rightarrow \mathrm{V} 1 \rightarrow 1 \mathrm{~A} / \mathrm{B}$ & $\mathrm{V} 5 \mathrm{a} / \mathrm{b}$ & $\mathrm{C} 1 \mathrm{a} / \mathrm{b} \rightarrow \mathrm{V} 5 \mathrm{a} / \mathrm{b} \rightarrow 4 \mathrm{~A} / \mathrm{B}$ \\
\hline $\mathrm{V} 2 \mathrm{a} / \mathrm{b}$ & $1 \mathrm{~A} / \mathrm{B} \rightarrow \mathrm{V} 2 \mathrm{a} / \mathrm{b} \rightarrow 2 \mathrm{~A} / \mathrm{B}$ & $\mathrm{V} 6 \mathrm{a} / \mathrm{b}$ & $4 \mathrm{~A} / \mathrm{B} \rightarrow \mathrm{V} 6 \mathrm{a} / \mathrm{b} \rightarrow 5 \mathrm{~A} / \mathrm{B}$ \\
\hline $\mathrm{V} 3 \mathrm{a} / \mathrm{b}$ & $2 \mathrm{~A} / \mathrm{B} \rightarrow \mathrm{V} 3 \mathrm{a} / \mathrm{b} \rightarrow 3 \mathrm{~A} / \mathrm{B}$ & $\mathrm{V} 7$ & $5 \mathrm{~A} / \mathrm{B} \rightarrow \mathrm{V} 7 \rightarrow 6$ \\
\hline $\mathrm{V} 4 \mathrm{a} / \mathrm{b}$ & $3 \mathrm{~A} / \mathrm{B} \rightarrow \mathrm{V} 4 \mathrm{a} / \mathrm{b} \rightarrow \mathrm{C} 1 \mathrm{a} / \mathrm{b}$ & $\mathrm{V} 8$ & $6 \rightarrow \mathrm{V} 8 \rightarrow 13$ \\
\hline
\end{tabular}

Config. 4: CST Pump Flow Rate Calibration Valve Configuration (Forward Flush bypass to Line $12 \mathrm{~A} / \mathrm{B}$

\begin{tabular}{|c|c|}
\hline Valve & Direction \\
\hline \hline $\mathrm{V} 1$ & $\mathrm{~L} 1 \rightarrow \mathrm{V} 1 \rightarrow 1 \mathrm{~A} / \mathrm{B}$ \\
\hline $\mathrm{V} 2 \mathrm{a} / \mathrm{b}$ & $1 \mathrm{~A} / \mathrm{B} \rightarrow \mathrm{V} 2 \mathrm{a} / \mathrm{b} \rightarrow 2 \mathrm{~A} / \mathrm{B}$ \\
\hline $\mathrm{V} 3 \mathrm{a} / \mathrm{b}$ & $2 \mathrm{~A} / \mathrm{B} \rightarrow \mathrm{V} 3 \mathrm{a} / \mathrm{b} \rightarrow 12 \mathrm{~A} / \mathrm{B}$ \\
\hline
\end{tabular}


HNF-SD-RE-TPI-002, Rev. 0

\begin{tabular}{|c|c|c|c|c|c|c|c|c|c|}
\hline \multicolumn{6}{|c|}{ Sheet 3: Pump Calibration Flow Measurement } & \multicolumn{4}{|c|}{ Checksheet \# } \\
\hline \multicolumn{7}{|c|}{ Executed By: } & \multicolumn{3}{|c|}{ Pump Knob Position: __ } \\
\hline \multirow[t]{3}{*}{ Column } & \multirow{3}{*}{$\begin{array}{c}\text { Discharge } \\
\text { point } \\
\text { (line \#) }\end{array}$} & \multicolumn{4}{|c|}{ Run 1} & \multicolumn{4}{|c|}{ Run 2} \\
\hline & & \multirow[t]{2}{*}{ Time } & \multicolumn{2}{|c|}{ Mass, $g$} & \multirow{2}{*}{$\begin{array}{c}\text { Rate } \\
\mathrm{mL} / \mathrm{mi} \\
\mathrm{n}\end{array}$} & \multirow[t]{2}{*}{ Time } & \multicolumn{2}{|c|}{ Mass, g } & \multirow{2}{*}{$\begin{array}{c}\text { Rate } \\
\text { InL/mi } \\
n\end{array}$} \\
\hline & & & Init. & Final & & & Init. & Final & \\
\hline \multirow{4}{*}{$\mathrm{Cla}$} & 11 & & & & & & & & \\
\hline & 14 & & & & & & & & \\
\hline & 13 & & & & & & & & \\
\hline & $12 \mathrm{~A}$ & & & & & & & & \\
\hline \multirow{4}{*}{ c1b } & 11 & & & & & & & & \\
\hline & 14 & & & & & & & & \\
\hline & 13 & & & & & & & & \\
\hline & $12 \mathrm{~B}$ & & & & & & & & \\
\hline \multirow[t]{3}{*}{ Column } & \multirow{3}{*}{$\begin{array}{c}\text { Discharge } \\
\text { point } \\
\text { (Line \#) }\end{array}$} & \multicolumn{4}{|c|}{ Run 3} & \multirow{3}{*}{\multicolumn{4}{|c|}{ Avg flow rate $\mathrm{ml} / \mathrm{min}$}} \\
\hline & & Time & & g & Rate & & & & \\
\hline & & & Init. & Final & $\begin{array}{c}\mathrm{mL} / \mathrm{ml} \\
\mathrm{n}\end{array}$ & & & & \\
\hline \multirow{4}{*}{$\mathrm{Cla}$} & 11 & & & & & & & & \\
\hline & 14 & & & & & & & & \\
\hline & 13 & & & & & & & & \\
\hline & $12 \mathrm{~A}$ & & & & & & & & \\
\hline \multirow{4}{*}{$\mathrm{C} 1 \mathrm{~b}$} & 11 & & & & & & & & \\
\hline & 14 & & & & & & & & \\
\hline & 13 & & & & & & & & \\
\hline & $12 \mathrm{~B}$ & & & & & & & & \\
\hline
\end{tabular}


Sheet 4: Waste Feed Preparation

Objective: Prepare $5000 \mathrm{~mL}$ batch of waste feed for CST sorbent test.

Executed for Test Procedure Step: 4.2 .3

Executed by (print name):
Date/time:

Checksheet\#

1. A composite $3.8 \mathrm{~L}$ polyethylene jug will be used in the test. The feed material will be prepared one liter at a time until five liters are ready to begin the test. Excess feed will be stored in $1 \mathrm{~L}$ polyethylene bottles and added to the $3.8 \mathrm{~L}$ jug when $2 \mathrm{~L}$ of feed have been used up. The following masses have been calculated for an estimated as-received waste density of $1.43 \mathrm{~g} / \mathrm{mL}$.

2. Decant 4 waste sample bottles into a $2 \mathrm{~L}$ glass beaker. Record bottle \#s in lab notebook. Take an aliquot from this beaker and measure tank waste density, $\mathrm{g} / \mathrm{mL}$. Add waste from another sample bottle to total 809.7 $\mathrm{g}(566.25 \mathrm{~mL})$ waste liquor in the $2 \mathrm{~L}$ glass beaker. Actual mass added $=$ g. Actual mass added $(\mathrm{g}) /$ density $(\mathrm{g} / \mathrm{mL})=$ $\mathrm{mL}$.

3. Add $455.4 \mathrm{~g}(433.75 \mathrm{~mL}) 0.4689 \underline{\mathrm{M} \mathrm{NaOH}}$ solution to mixing vessel. Actual mass added g.

4. Mix on magnetic stirring plate until no crystals are visible. Minimize heating during dissolution.

5. Allow to settle, decant clear liquor into feed tank $\mathrm{T} 2$, if solids are present then go to either step 6 or 7 before decanting into the $3.8 \mathrm{~L}$ vessel.

6. If solids do not settle out, do the following:

a. Tare centrifuge cones.

b. Centrifuge the waste material mixture, and decant clear liquid into feed tank T2.

c. At completion, weigh all centrifuge cones to determine the accumulated solids mass.

7. If solids are present and settle out, then decant the liquid very carefully into the $3.8 \mathrm{~L}$ vessel taking care to minimize the amount of liquid left over. Transfer the solids into a $250 \mathrm{~mL}$ vial labeled "7AN Solids".

Tare wt. of "7AN Solids" = g.

Repeat steps 2 thru 7 for each $1 \mathrm{~L}$ batch. In the lab notebook record observations of liquor clarity, color and any suspended solids.

8. Upon completion of waste feed addition to $\mathrm{T} 2$, pipette a $15 \mathrm{~mL}$ aliquot into prelabeled sample vial $\mathrm{F} 1 . \mathrm{T} 2$ is again sampled, in vial $\mathrm{F} 2$, after adding $2 \mathrm{~L}$ waste to $\mathrm{T} 2$.

9. Take an additional aliquot from T2 and measure, and record density

10. Dry contents of "7AN Solids". Gross Wt. Net Wt.

Place two samples of separated solids in prelabeled sample vials FS1 and FS2. 
Sheet 5: Pump Flow Rate Set and Measurement

Executed for Test Procedure Step: 4 4.2.4

Checksheet\#

Executed by:

Date/time:

Target Flow Rate: $\mathrm{g} / \mathrm{hr}$

Receiver/bottle tare: grams

Feed Material:

Density $\mathrm{g} / \mathrm{mL}$

Place Effluent Line (12A/B) into receiver and Feed Line (L1) into Feed Tank.

Valve Placement/Confirmation (See Figure A-1) other valves closed:

Config. 4: CST Pump Flow Rate Calibration Valve Configuration (Foward flush bypass to Line 12A/B)

\begin{tabular}{|c|c|}
\hline Valve & Direction \\
\hline $\mathrm{V} 1$ & $\mathrm{~L} 1 \rightarrow \mathrm{V} 1 \rightarrow 1 \mathrm{~A} / \mathrm{B}$ \\
\hline $\mathrm{V} 2 \mathrm{a} / \mathrm{b}$ & $1 \mathrm{~A} / \mathrm{B} \rightarrow \mathrm{V} 2 \mathrm{a} / \mathrm{b} \rightarrow 2 \mathrm{~A} / \mathrm{B}$ \\
\hline $\mathrm{V} 3 \mathrm{a} / \mathrm{b}$ & $2 \mathrm{~A} / \mathrm{B} \rightarrow \mathrm{V} 3 \mathrm{a} / \mathrm{b} \rightarrow 12 \mathrm{~A} / \mathrm{B}$ \\
\hline
\end{tabular}

\begin{tabular}{|c|c|c|c|c|c|c|c|c|c|}
\hline \multirow{2}{*}{$\begin{array}{l}\text { Time } \\
\text { (min) }\end{array}$} & \multicolumn{3}{|c|}{ Mass (g) } & \multirow{2}{*}{$\begin{array}{l}\text { Flow } \\
(\mathrm{g} / \mathrm{hr})\end{array}$} & \multirow{2}{*}{$\begin{array}{l}\text { Time } \\
\text { (min) }\end{array}$} & \multicolumn{3}{|c|}{ Mass (g) } & \multirow{2}{*}{$\begin{array}{l}\text { Flow } \\
(\mathrm{g} / \mathrm{hr})\end{array}$} \\
\hline & Tare & Gross & Net & & & Tare & Gross & Net & \\
\hline & & & & & & & & & \\
\hline & & & & & & & & & \\
\hline & & & & & & & & & \\
\hline & & & & & & & & & \\
\hline & & & & & & & & & \\
\hline & & & & & & & & & \\
\hline
\end{tabular}

Flow Rate $=$ Average of last three test periods without pump setting change

Flow Rate $=$ $\mathrm{g} / \mathrm{hr}=$ $\mathrm{mL} / \mathrm{hr}$

Get Regression Curve from Sheet 3 Performance for Configuration 1 relative to Configuration 4.

Full System Flow: $\mathrm{mL} / \mathrm{hr}$ 
HNF-SD-RE-TPI-002, Rev. 0

Sheet 6: Effluent Collection Record

Executed for Test Procedure Step:

Checksheet\#

Executed by:

Date/time:

Receiver/bottle tare: grams

Feed Line (L1) into Feed Tank: Primary Column:

Feed Material:

Density $\mathrm{g} / \mathrm{mL}$

Effluent Line (11) into

Valve Placement/Confirmation (See Figure A-1, other valves closed):

Config. 1: Full System Forward Feed Valving Configuration (Forward flow to Line 11)

\begin{tabular}{|c|c|c|c|}
\hline Valve & Direction & Valve & Direction \\
\hline \hline $\mathrm{V} 1$ & $\mathrm{~L} 1 \rightarrow \mathrm{V} 1 \rightarrow 1 \mathrm{~A} / \mathrm{B}$ & $\mathrm{V} 8$ & $6 \rightarrow \mathrm{V} 8 \rightarrow 7$ \\
\hline $\mathrm{V} 2 \mathrm{a} / \mathrm{b}$ & $\mathrm{AA} / \mathrm{B} \rightarrow \mathrm{V} 2 \mathrm{a} / \mathrm{b} \rightarrow 2 \mathrm{~A} / \mathrm{B}$ & $\mathrm{V} 9$ & $7 \rightarrow \mathrm{V} 9 \rightarrow \mathrm{C} 2$ \\
\hline $\mathrm{V} 3 \mathrm{a} / \mathrm{b}$ & $2 \mathrm{~A} / \mathrm{B} \rightarrow \mathrm{V} 3 \mathrm{a} / \mathrm{b} \rightarrow 3 \mathrm{~A} / \mathrm{B}$ & $\mathrm{V} 10$ & $\mathrm{C} 2 \rightarrow \mathrm{V} 10 \rightarrow 8$ \\
\hline $\mathrm{V} 4 \mathrm{a} / \mathrm{b}$ & $3 \mathrm{~A} / \mathrm{B} \rightarrow \mathrm{V} 4 \mathrm{a} / \mathrm{b} \rightarrow \mathrm{C} 1 \mathrm{a}$ & $\mathrm{V} 11$ & $8 \rightarrow \mathrm{V} 11 \rightarrow 9$ \\
\hline $\mathrm{V} 5 \mathrm{a} / \mathrm{b}$ & $\mathrm{C} 1 \mathrm{a} / \mathrm{b} \rightarrow \mathrm{V} 5 \mathrm{a} / \mathrm{b} \rightarrow 4 \mathrm{~A} / \mathrm{B}$ & $\mathrm{V} 12$ & $9 \rightarrow \mathrm{V} 12 \rightarrow \mathrm{C} 3$ \\
\hline $\mathrm{V} 6 \mathrm{a} / \mathrm{b}$ & $4 \mathrm{~A} / \mathrm{B} \rightarrow \mathrm{V} 6 \mathrm{a} / \mathrm{b} \rightarrow 5 \mathrm{~A} / \mathrm{B}$ & $\mathrm{V} 13$ & $\mathrm{C} 3 \rightarrow \mathrm{V} 13 \rightarrow 10$ \\
\hline $\mathrm{V} 7$ & $5 \mathrm{~A} / \mathrm{B} \rightarrow \mathrm{V} 7 \rightarrow 6$ & $\mathrm{~V} 14$ & $10 \rightarrow \mathrm{V} 14 \rightarrow 11$ \\
\hline
\end{tabular}

Flow Rate (from Sheet 5, Checksheet \# ): $\mathrm{mL} / \mathrm{hr}$

Pump On: (time/date)

Observations:

Pump Off: (time/date)

Mass Collected (gross receiver): g (net collected):

(Use additional sheets for mass collection if collection vessel is changed) 
Executed for Test Procedure Step: 4 4.2.5.2 Checksheet\#

Executed by:

Completed Date/time: Runtime

Feed Line (L1) into Feed Tank: Primary Column:

Feed Material: Sp. gravity (from Sheet 4):

Sample Vial plus stopper Tare weight: g

Place effluent Line (13) into Flush Vial.

Change V8 position: $\quad$ from: $6 \rightarrow \mathrm{V} 8 \rightarrow 7$ to: $6 \rightarrow \mathrm{V} 8 \rightarrow 13$

Flow Rate (from Sheet 5, Checksheet\#___ ) :_____ $\mathrm{mL} / \mathrm{hr}$

Collect $\sim 2 \mathrm{~mL}$ in Flush Vial (approx. $8 \mathrm{~min}$ ); $\quad$ Start (Runtime)

Place line 13 into sample vial End (Runtime)

Collect $\sim 5 \mathrm{~mL}$ in sample vial (approx. $19 \mathrm{~min}$ ) Start (Runtime)

Time of collection: End (Runtime) $\min \quad \mathrm{sec}$

Redirect valve V8 back to line 7 as follows:

Change V8 position: $\quad$ from: $6 \rightarrow \mathrm{V} 8 \rightarrow 13$ to: $6 \rightarrow \mathrm{V} 8 \rightarrow 7$

Weight Sample + stopper: g, Net Sample: g

Flow rate $=$ Net Sample / sample time $=$ $\mathrm{g} / \mathrm{hr}$ $\mathrm{g} / \mathrm{hr} /$ density $=$ $\mathrm{mL} / \mathrm{hr}$

Observations: 
HNF-SD-RE-TPI-002, Rev. 0

Sheet 8: Primary Column Sample Record

Checksheet\#

Executed for Test Procedure Step: 4.2.5.2 Executed by:

Completed Date/time:

Run Start (Date/time):

\begin{tabular}{|c|c|c|c|c|c|}
\hline Simple & Projected Run Time & $\begin{array}{l}\text { Projected Clock } \\
\text { Time }\end{array}$ & $\begin{array}{l}\text { Actual Clock } \\
\text { Time }\end{array}$ & On-Line $\gamma$ & Feed Temp. (C) \\
\hline CIE-1 & $1 \mathrm{hr} 0 \mathrm{~min}$ & & & & \\
\hline C 1 E-2 & $17 \mathrm{hr} 40 \mathrm{~min}$ & & & & \\
\hline C1E-3 & $34 \mathrm{hr} 20 \mathrm{~min}$ & & & & \\
\hline CIE-4 & $51 \mathrm{hr} \quad 0 \mathrm{~min}$ & & & & \\
\hline C1E-5 & $67 \mathrm{hr} 40 \mathrm{~min}$ & & & & \\
\hline C1E-6 & $84 \mathrm{lor} 20 \mathrm{~min}$ & & & & \\
\hline C1E-7 & $101 \mathrm{hr} 0 \mathrm{~min}$ & & & & \\
\hline CIE-8 & 117 hr $40 \mathrm{~min}$ & & & & \\
\hline CIE-9 & 134 hг $20 \mathrm{~min}$ & & & & \\
\hline C1E-10 & $151 \mathrm{hr} 0 \mathrm{~min}$ & & & & \\
\hline C1E-11 & $167 \mathrm{hr} 40 \mathrm{~min}$ & & & & \\
\hline $\mathrm{C} 1 \mathrm{E}-12$ & $176 \mathrm{hr} \quad 0 \mathrm{~min}$ & & & & \\
\hline $\mathrm{C} 1 \mathrm{E}-13$ & 184 hr $20 \mathrm{~min}$ & & & & \\
\hline $\mathrm{C} 1 \mathrm{E}-14$ & $192 \mathrm{hr} 40 \mathrm{~min}$ & & & & \\
\hline C1E-15 & $201 \mathrm{hr} 0 \mathrm{~min}$ & & & & \\
\hline C1E-16 & 209 hr 20 min & & & & \\
\hline $\mathrm{C} 1 \mathrm{E}-17$ & $217 \mathrm{hr} 40 \mathrm{~min}$ & & & & \\
\hline C1E- 18 & $226 \mathrm{hr} \quad 0 \mathrm{~min}$ & & & & \\
\hline CIE-19 & $234 \mathrm{hr} 20 \mathrm{~min}$ & & & & \\
\hline C1E-20 & $242 \mathrm{lr} 40 \mathrm{~min}$ & & & & \\
\hline C1E-21 & $251 \mathrm{hr} 0 \mathrm{~min}$ & & & & \\
\hline C1E-22 & $259 \mathrm{hr} 20 \mathrm{~min}$ & & & & \\
\hline $\mathrm{C} 1 \mathrm{E}-23$ & $267 \mathrm{hr} 40 \mathrm{~min}$ & & & & \\
\hline $\mathrm{C} 1 \mathrm{E}-24$ & $276 \mathrm{hr} 0 \mathrm{~min}$ & & & & \\
\hline
\end{tabular}


Sheet 8: Primary Column Sample Record - continued

HNF-SD-RE-TPI-002, Rev. 0 Checksheet\#

\begin{tabular}{|l|l|l|l|l|l||}
\hline Sample & Projected Run Time & $\begin{array}{c}\text { Projected Clock } \\
\text { Time }\end{array}$ & $\begin{array}{c}\text { Actual Clock } \\
\text { Time }\end{array}$ & On-Line $\gamma$ & Feed Temp. (C) \\
\hline C1E-25 & $284 \mathrm{hr} 20 \mathrm{~min}$ & & & & \\
\hline C1E-26 & $292 \mathrm{hr} 40 \mathrm{~min}$ & & & & \\
\hline C1E-27 & $301 \mathrm{hr} 0 \mathrm{~min}$ & & & & \\
\hline C1E-28 & $309 \mathrm{hr} 20 \mathrm{~min}$ & & & & \\
\hline C1E-29 & $317 \mathrm{hr} 40 \mathrm{~min}$ & & & & \\
\hline C1E-30 & $326 \mathrm{hr} 0 \mathrm{~min}$ & & & & \\
\hline C1E-31 & $334 \mathrm{hr} 20 \mathrm{~min}$ & & & & \\
\hline
\end{tabular}


HNF-SD-RE-TPI-002, Rev. 0

Sheet 9: Secondary (C2) Column Sampling

Executed for Test Procedure Step:

Checksheet\#

Executed by:

Completed Date/time:

Feed Line (L1) into Feed Tank:

Feed Material:

Sp. gravity (from Sheet 4):

Sample Vial plus stopper Tare weight: g

Effluent Line (14) into_Flush Vial

Change V11 position: $\quad$ from: $8 \rightarrow \mathrm{V} 11 \rightarrow 9$ to: $8 \rightarrow \mathrm{V} 11 \rightarrow 14$

Flow Rate (from Sheet 4, Checksheet\#___ ) ___ g/hr

Collect $\sim 2 \mathrm{~mL}$ in Flush Vial (approx. $8 \mathrm{~min}$ ); Start (Runtime)

Place line 14 into sample vial

End (Runtime)

Collect $\sim 5 \mathrm{~mL}$ in sample vial (approx. $19 \mathrm{~min}$ ); Start (Runtime) End (Runtime)

Time of collection: $\min \_$sec

Redirect valve V11 back to line 9

Change V11 position: $\quad$ from: $8 \rightarrow \mathrm{V} 11 \rightarrow 14$ to: $8 \rightarrow \mathrm{V} 11 \rightarrow 9$

Weight Sample + stopper: g, Net Sample: $\mathrm{g}$

Flow rate $=$ Net Sample / sample time $=$ $\mathrm{g} / \mathrm{hr}$ $\mathrm{g} / \mathrm{hr} /$ density $=$ $\mathrm{mL} / \mathrm{hr}$

Observations: 
HNF-SD-RE-TPI-002, Rev. 0

Sheet 10: Secondary (C2) Column Sample Record Checksheet\#

Executed for Test Procedure Step: 4.2.5.3 Executed by:

Completed Date/time:

Run Start (Date/time):

\begin{tabular}{|l|l|l|l|l|l||}
\hline Sitmple & Projected Run Time & $\begin{array}{c}\text { Projected Clock } \\
\text { Time }\end{array}$ & $\begin{array}{c}\text { Actual Clock } \\
\text { Time }\end{array}$ & On-Line $\gamma$ & Feed Temp. (C) \\
\hline $\mathrm{C} 2 \mathrm{E}-1$ & $17 \mathrm{hr} 10 \mathrm{~min}$ & & & & \\
\hline $\mathrm{C} 2 \mathrm{E}-2$ & $50 \mathrm{hr} 30 \mathrm{~min}$ & & & & \\
\hline $\mathrm{C} 2 \mathrm{E}-4$ & $117 \mathrm{hr} 10 \mathrm{~min}$ & & & \\
\hline $\mathrm{C} 2 \mathrm{E}-5$ & $150 \mathrm{hr} 30 \mathrm{~min}$ & & & \\
\hline $\mathrm{C} 2 \mathrm{E}-6$ & $183 \mathrm{hr} 50 \mathrm{~min}$ & & & & \\
\hline $\mathrm{C} 2 \mathrm{E}-7$ & $217 \mathrm{hr} 10 \mathrm{~min}$ & & & & \\
\hline $\mathrm{C} 2 \mathrm{E}-8$ & $250 \mathrm{hr} 30 \mathrm{~min}$ & & & & \\
\hline $\mathrm{C} 2 \mathrm{E}-9$ & $283 \mathrm{hr} 50 \mathrm{~min}$ & & & & \\
\hline $\mathrm{C} 2 \mathrm{E}-10$ & $317 \mathrm{hr} 10 \mathrm{~min}$ & & & & \\
\hline
\end{tabular}


HNF-SD-RE-TPI-002, Rev. 0

Sheet 11: Primary Column C1a/b Reverse Feed Valving

Executed for Test Procedure Step:

Checksheet\#

Executed by:

Date/time:

Receiver/bottle tare: grams

Feed Line (LI) into Feed Tank \#

Feed Material:

Density $\mathrm{g} / \mathrm{mL}$

Effluent Line (12 A/B, Configuration 5) into

Valve Placement/Confirmation (See Figure A-1) for Configuration 5, other valves closed:

Config. 5: Column $\mathrm{C} 1 \mathrm{a} / \mathrm{b}$ Reverse Flush Valving Configuration (Reverse flush to Line 12A/B)

\begin{tabular}{|c|c|c|c||}
\hline Valve & Direction & Valve & Direction \\
\hline \hline $\mathrm{V} 1$ & $\mathrm{~L} 1 \rightarrow \mathrm{V} 1 \rightarrow 1 \mathrm{~A} / \mathrm{B}$ & $\mathrm{V} 5 \mathrm{~A} / \mathrm{B}$ & $4 \mathrm{~A} / \mathrm{B} \rightarrow \mathrm{V} 5 \mathrm{~A} / \mathrm{B} \rightarrow \mathrm{C} 1 \mathrm{~A} / \mathrm{B}$ \\
\hline $\mathrm{V} 2 \mathrm{~A} / \mathrm{B}$ & $1 \mathrm{~A} / \mathrm{B} \rightarrow \mathrm{V} 2 \mathrm{~A} / \mathrm{B} \rightarrow 16 \mathrm{~A} / \mathrm{B}$ & $\mathrm{V} 4 \mathrm{~A} / \mathrm{B}$ & $\mathrm{C} 1 \mathrm{~A} / \mathrm{B} \rightarrow \mathrm{V} 4 \mathrm{~A} / \mathrm{B} \rightarrow 3 \mathrm{~A} / \mathrm{B}$ \\
\hline $\mathrm{V} 6 \mathrm{~A} / \mathrm{B}$ & $16 \mathrm{~A} / \mathrm{B} \rightarrow \mathrm{V} 6 \mathrm{~A} / \mathrm{B} \rightarrow 4 \mathrm{~A} / \mathrm{B}$ & $\mathrm{V} 3 \mathrm{~A} / \mathrm{B}$ & $3 \mathrm{~A} / \mathrm{B} \rightarrow \mathrm{V} 3 \mathrm{~A} / \mathrm{B} \rightarrow 12 \mathrm{~A} / \mathrm{B}$ \\
\hline
\end{tabular}

Pump On: (time/date); Runtime

Observations:

Pump Off: (time/date); Runtime

Mass Collected (gross receiver): g (net collected):

(Use additional sheets for mass collection if collection vessel changed) 
Sheet 12: Guard Columns C2 \& C3 Reverse Feed Valving

Executed for Test Procedure Step:

Checksheet\#

Executed by:

Date/time:

Receiver/bottle tare: grams

Feed Line (L1) into Feed Tank \#

Feed Material:

Density $\mathrm{g} / \mathrm{mL}$

Effluent Line (13, Configuration 6) into

Valve Placement/Confirmation (See Figure A-1) for Configuration 6, other valves closed:

Config. 6: Reverse Feed Valving Configuration (Reverse flush through guard columns)

\begin{tabular}{|c|c|c|c|}
\hline Valve & Direction & Valve & Direction \\
\hline \hline $\mathrm{V} 1$ & $\mathrm{~L} 1 \rightarrow \mathrm{V} 1 \rightarrow 1 \mathrm{~B}$ & $\mathrm{~V} 11$ & $9 \rightarrow \mathrm{V} 11 \rightarrow 8$ \\
\hline $\mathrm{V} 2 \mathrm{~b}$ & $1 \mathrm{~B} \rightarrow \mathrm{V} 2 \mathrm{~b} \rightarrow 15$ & $\mathrm{~V} 10$ & $8 \rightarrow \mathrm{V} 10 \rightarrow \mathrm{C} 2$ \\
\hline $\mathrm{V} 14$ & $15 \rightarrow \mathrm{V} 14 \rightarrow 10$ & $\mathrm{~V} 9$ & $\mathrm{C} 2 \rightarrow \mathrm{V} 9 \rightarrow 7$ \\
\hline $\mathrm{V} 13$ & $10 \rightarrow \mathrm{V} 13 \rightarrow \mathrm{C} 3$ & $\mathrm{~V} 8$ & $7 \rightarrow \mathrm{V} 8 \rightarrow 13$ \\
\hline $\mathrm{V} 12$ & $\mathrm{C} 3 \rightarrow \mathrm{V} 12 \rightarrow 9$ & & \\
\hline
\end{tabular}

Puinp On: (time/date)

Observations:

Pump Off: (time/date)

Mass Collected (gross receiver):

(Use additional sheets for mass collection if collection vessel is changed)

$g$ (net collected): g 


\section{Sheet 13: CST Sorbent Dissolution}

Objective: To remove and dissolve the CST sorbent at the end of the test. This procedure will facilitate waste disposal.

Sorbent Dissolution Procedure: Checksheet\#

NOTE: The CST sorbent will not be analyzed and will be dissolved in a batch.

1. Confirm the following valve positions:

Cla V4a \& V5a Closed

C1b V4b \& V5b Closed

C2 V9 \& V10 Closed

C3 V12 \& V13 Closed

2. Crimp the tubing to inhibit leaks, two crimps approximately 1 " apart on each side of the column.

3. Remove column Cla from the retainers.

4. Cut the line between the crimps above and below the column.

5. Remove the top of the column.

6. Deposit the sorbent into a 2 liter beaker by scraping and rinsing. The beaker will be large enough to hold all the CST sorbent ( $\sim 21$ grams) plus the required volume to dissolve the sorbent as indicated in Step 8.

7. Repeat the Steps 3 through 6 for columns C1b, C2, and C3.

8. Digest the sorbent by sequentially adding:

$610 \mathrm{~mL}$ DI water

$210 \mathrm{~mL}$ of $2 \underline{\mathrm{M}} \mathrm{HCL}$

$105 \mathrm{~mL}$ of $1 \underline{\mathrm{M}} \mathrm{HF}$

9. Place on a hot plate with a magnetic stirrer. Heat gently until the CST sorbent is dissolved.

10. Pour cooled solution into waste receiver labeled pending disposal through hot cell drain. 
Sheet 14: CST Sorbent Bed Density Determination

Objective: To determine the mass to volume ratio of the conditioned CST sorbent.

\section{Procedure:}

Checksheet\#

1. Dry approximately 100 grams of sorbent in a tared evaporating dish at $103^{\circ} \mathrm{C}$ for 4 hours.

2. Cool in a desiccator and weigh on an analytical balance to find per cent moisture.

Weight of the sorbent + evap dish: g

Weight of the evaporating dish: g

Weight of the CST Sorbent: g

3. Mix approximately 50 grams of the sorbent with $18 \mathrm{Mohm} \cdot \mathrm{cm}$ water and slurry the sorbent into each of the glass columns to approximately $50 \%$ of the column volume.

4. Condition the sorbent as follows (per instructions from the manufacturer) ):

a. Backflush the column with a high superficial velocity to backwash fines from the bed (usually $200 \%$ of the initial height of the bed). When evidence of fines ceases in the effluent, stop the flow of water and allow the bed to settle.

b. Using $0.22 \mathrm{M} \mathrm{NaOH}$, condition the bed in a downflow manner. Monitor the $\mathrm{pH}$ of the bed and when the effluent remains at a $\mathrm{pH}$ equal to or slightly greater than the $\mathrm{pH}$ of the waste feed $(\mathrm{pH} \approx 13.3)$. Check the $\mathrm{pH}$ in the effluent. When the $\mathrm{pH}$ value stabilizes, turn off the pump, allow the bed to settle. After settling, mark the top of the bed. Remove the sorbent from the column and determine the volume $(\mathrm{mL})$ that the bed occupied.

c. Wash the sorbent with $18 \mathrm{Mohm} \cdot \mathrm{cm}$ water until the $\mathrm{NaOH}$ has been flushed from the system. Analytically transfer the sorbent to a tared evaporating dish, washing all the sorbent from the column. Dry the sorbent overnight at $103^{\circ} \mathrm{C}$ and determine the dry mass of the sorbent. 
Sheet 14: CST Sorbent Bed Density Determination - cont'd. Checksheet\#

d. Repeat this for five iterations and use the average

\begin{tabular}{|c|c|c|c|c|c|c|}
\hline Stumple & $\begin{array}{l}\text { Settled Bed } \\
\text { Volume, } \mathrm{mL}\end{array}$ & $\begin{array}{l}\text { Wt. of Evap } \\
\text { Dish, g }\end{array}$ & $\begin{array}{l}\text { Dry Wt of } \\
\text { (Absorbent }+ \\
\text { Evap Dish) g }\end{array}$ & $\begin{array}{l}\text { Net } \\
\text { Sorbent } \\
\text { Wt. g }\end{array}$ & $\begin{array}{l}\text { Density (dry g } \\
\text { /mL bed) }\end{array}$ & $\begin{array}{l}\text { Avg. } \\
\text { Density, } \\
\mathrm{g} / \mathrm{mL} \text { bed }\end{array}$ \\
\hline \multicolumn{6}{|l|}{1.} & \\
\hline \multicolumn{6}{|l|}{2} & \\
\hline \multicolumn{6}{|l|}{3} & \\
\hline \multicolumn{6}{|l|}{4} & \\
\hline 5 & & & & & & \\
\hline
\end{tabular}

\section{Bulk Density Measurements:}

Take a graduated cylinder $(25 \mathrm{~mL})$ and tare on a top loading balance. Using the other half of the sorbent from step 2, pour into the cylinder and tap the side to settle the sorbent. Record the weight of the cylinder and sorbent on the chart below. Using tongs to handle the cylinder, record the level of the sorbent in $\mathrm{mL}$. Repeat this operation for five iterations and use the average for the density.

\begin{tabular}{||c|c|c|c||}
\hline $\begin{array}{c}\text { Weight of cylinder } \\
\text { plus sorbent }\end{array}$ & $\begin{array}{c}\text { Weight of } \\
\text { cylinder }\end{array}$ & $\begin{array}{c}\text { Weight of } \\
\text { sorbent }\end{array}$ & $\begin{array}{c}\text { mL of sorbent } \\
\text { in cylinder }\end{array}$ \\
\hline & & & \\
\hline & & & \\
\hline & & & \\
\hline & & & \\
\hline & & & \\
\hline
\end{tabular}

Average Weight of Sorbent

Average $\mathrm{mL}$ of Sorbent

Density
$=$

$=$

$=$ $\mathrm{g} / \mathrm{mL}$ 


\section{Sheet 15: $\mathrm{NaOH}$ Solution Preparation from 5.0 mole/L Stock}

Objective: $\mathrm{NaOH}$ solutions of different molarity are needed in the hot cell for preparing waste feed and for flushes. This data sheet gives the procedure to prepare $1 \mathrm{~kg}$ of each of these $\mathrm{NaOH}$ solutions from 5.0 mole/L stock solution. Masses of desired solution other than $1 \mathrm{~kg}$ may be linearly scaled using the table below.

\begin{tabular}{|l|r|c|c|}
\hline $\mathrm{NaOH}$ Preparation $/ \mathrm{Kg}$ & \multicolumn{3}{|c|}{ Stock $=5$ mole $/ \mathrm{L}$} \\
\hline $\begin{array}{l}\text { Prepared Solution } \\
(\mathrm{mol} / \mathrm{L})\left(27^{\circ} \mathrm{C}\right)\end{array}$ & $\begin{array}{c}\text { Stock } \\
\text { Soln }(\mathrm{g})\end{array}$ & $\begin{array}{c}\mathrm{H} 2 \mathrm{O} \\
(\mathrm{g})\end{array}$ & $\begin{array}{c}\text { Total } \\
(\mathrm{g})\end{array}$ \\
\hline 0.22 & 51.65 & 948.35 & 1000 \\
\hline 0.4689 & 108.67 & 891.33 & 1000 \\
\hline 5.0 & 1000.00 & 0.00 & 1,000 \\
\hline
\end{tabular}

\section{Procedure:}

\section{Checksheet\#}

1. Quantity of $\mathrm{NaOH}$ solution to be prepared g; desired strength $\mathrm{mol} / \mathrm{L}$

2. Quantity of water required g.

3. For desired strength, from Table above, meter water as:

Tare wt of Beaker\#1 and stirrer: $\mathrm{g}$

Wt. of Beaker\#1, stirrer and water: $\mathrm{g}$

Net wt. of water taken: g

4. Calculate and meter $\mathrm{NaOH}$, from Table above, as:

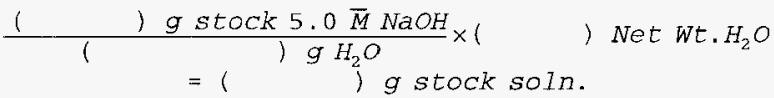

Tare wt of Beaker\#2: g

Wt. of Beaker $\# 2$ and $\mathrm{NaOH}$ : $\mathrm{g}$

Net wt. of $\mathrm{NaOH}$ : g

5. Slowly, over a few minutes, pour preweighed amt. of 5.0 mole/L stock $\mathrm{NaOH}$ solution into the water in the $1 \mathrm{~L}$ beaker on a stir plate, allowing time for blending. Record final solution temp. ${ }^{\circ} \mathrm{C}$.

Final wt. of (beaker + solution) $=$ g

Wt. of solution prepared $=$ g. 
HNF-SD-RE-TPI-002, Rev. 0

Appendix B: Material Safety Data Sheets

B-i 
HNF-SD-RE-TPI-002, Rev. 0

THIS PAGE INTENTIONALLY LEFT BLANK

B-ii 
HNF-SD-RE-TPI-002, Rev. 0

\section{List of Material Safety Data Sheets}

\section{Page}

Sodium Hydroxide, $\mathrm{NaOH} \ldots \ldots \ldots \ldots \ldots \ldots \ldots \ldots \ldots$. . . . . . . . . . .

Hydrofluoric Acid, $\mathrm{HF} \ldots \ldots \ldots \ldots \ldots \ldots \ldots \ldots \ldots$ B-5

Hydrochloric Acid, $\mathrm{HCl} \ldots \ldots \ldots \ldots \ldots \ldots \ldots$. . . . . . . . . . . . . . . . . .

UOP IONSIV Ion Exchanger Type IE-911 (Crystalline Silicotitanate) $\ldots \ldots \ldots \ldots$. . . 19

\section{MSDS Numbers}

MSDS

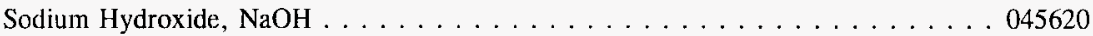

Hydrofluoric Acid, HF . . . . . . . . . . . . . . . . . . . . . . . 039275

Hydrochloric Acid, HCl . . . . . . . . . . . . . . . . . . . . . . 036338

UOP IONSIV Ion Exchanger Type IE-911 (Crystalline Silicotitanate) . . . . . . . 053329 
HNF-SD-RE-TPI-002, Rev, 0

THIS PAGE INTENTIONALLY LEFT BLANK 
HNF-SD-RE-TPI-002, Rev. 0

- $28 / 96 \quad: 2: 45: 58$

1-5B9-376-2128->

5893769964

Page 921

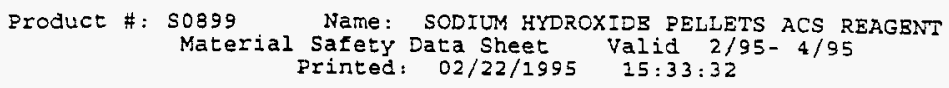

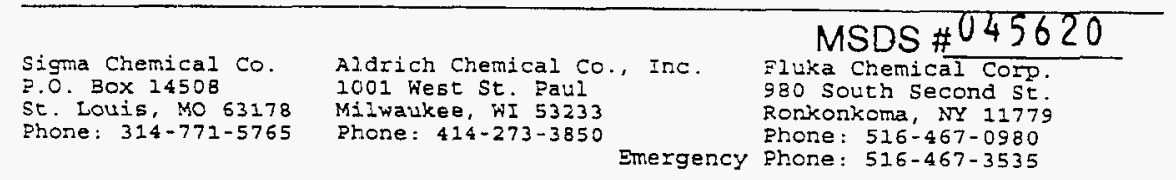
SECTION 1. - - - -
FRODUCT \#
SO899

NAME: $\quad$ SODIUM KYDROXIDE RELLETS ACS REAGENT

SECTION 2. - - - - - COMPOSITION/INEORMATION ON INGREDIENTS - - - -

CAS \#:1310-73-2

MF : FWAD

SYNONYMS

CAUSTIC SODA * HYDROXYDE DE SODIUM (FRENCH) * LEHIS-RED DEVIL LYZ *

LYE * NATRIUMHYDROXID (GERMAN) * NATRIUMHYDROXYDB (DUTCH) * SODA IYE * SODIO(IDROSSIDO DI) (ITALIAN) * SODIUM FIDRATE * SODIUM HYDROXIDB (ACGIH,OSFA) * SODIUM KYDROXIDE, SOLID (UN1823) (DOT) * SODIUM HYDROXIDE, SOLUTION (UN1824) (DOT) - SODIUM (HYOROXYDE DE) (FRENCH) UN1823 (DOT) * LN1824 (DOT) * WHITE CALSTIC *

SECTION 3. - - - - - - - - HAZARDS IDRNTIFICATION - - - - - -

- EL PRECAITIONARY STATEMENTS

CORROSTVR

CAUSES JURNS.

تRRMEUL EY IVHALATION, IN CONTACT WITK SKIN AND IF SWALLOWED.

IN CASE OF CONTACT WITH EYES, RINSE IMMEDIATELY WITH PLENTY OF WATER AIND SBEK MEDICAL ADVICE.

TAKE OFF IMMEDIATELY ALL CONTAMINATED CLOTHING.

WEAR SUITABLE FROTECTIVE CLOTHING, GLOVSS AND EYB/FACE PROTECTION.

SECTION 4. - - - - - - - - FIRST-AID MEASURES- - - - - - - - -

IN CASE OF CONTACT, IMMEDIATELY FLUSH EYES OR SKIN WITH COPIOUS

AMOUNTS OF WATER POR AT LEAST 15 MINUTES WHILE REMOVING CONTAMINATED CLOTHING AND SHOES.

ASSURE ADEQUATE FLUSHING OF THE EYES BY SBPARATING THE EYBLIDS NITH FINGERS.

IF INHALED, REMOVE TO ERESH AIR. IF NOT BREATHING GIVE ARTIFICIAL

RESPIRAIION. IF BREATHING IS DIFEICULT, GIVI OXYGEN.

IF SWALLOWED, WASH OUT MOUTH WITH WATER PROVIDED PERSON IS CONSCIOUS.

CAII A PHYSICIAN.

WASH CONTAMINATED CLOTHING BEFORE REUSE.

DISCARD CONTAMINATED SHOES.

SECTION 5. - - - - - - - - FIRE PIGHTING MEASURES - - - - - - - -

EXTINGUISHING MEDIA

USE EXTINGUISFING MEDIA APFROPRIATE TO SURROUNDING FIRE CONDITIONS. DO NOT USE WATER.

SFECIAL FIREFIGHTING PROCEDURES

WEAR SELE-CONTAINED BREATHING AFPARATUS AND PROTECTIVE CIOTHING TO PREVENT CONTACT WITH SKIN AND EYES. 
HNF-SD-RE-TPI-002, Rev. 0

ar $\cdot 3 / 36 \quad 12: 46: 49$

$1-589-376-2128->$

5893769954

Page 822

Product \#: S0899 Name: SODIUM HYDROXIDE PEILETS ACS REAGENT
Material Safety Data Sheet Valid $2 / 95-4 / 95$
Printed: 02/22/1995 $15: 33: 38$

UNUSUAL FIRE AND EXPLOSIONS HAZARDS

MSDS \#045620

EMITS TOXIC FUMES UNDER FIRE CONDITIONS.

SECTION 6. - - - - - - ACCIDENTAL RELEASE MEASURES - - _ - -

BVACUATE AREA.

WEAR SELF-CONTAINED BREATHING APPAPATUS, RUEBER BOOTS AND HEAVY

RUBBER GLOVES.

SWEEP UP, FIACE IN A BAG AND HOID FOR WASTE DISPOSAI.

VENTILATE AREA AND WASH SPILL SITE AFTER MATERIAL PICKUP IS COMPLBTB. SECIICK $\%$ - - - - - - - - HANDLING AND STORAGE- - - - - - - REFER TO SECEICIS 8 .

ADDITIONAL INFORMATION

CONTACT WITH ALUMINUM, TIN AND ZINC LIEERATES HYDROGEN GAS. CONTACT WITH NITROMETHANE AND OTHER SIMILAR NITRO COMPOUNDS CAUSZS FORMATION OF SHOCK-SENSITIVE SALTS.

SECTION 8. - - - - - EXPOSURE CONTROLS/PERSONAL PROTECTION - - . WEAR APRRORRIATE NIOSH/MSHA-APPROVED RESPIRATOR, CHEMICAI-RESISTANT GLOVES, SAFETY GOGGLES, OTHER FROTECTIVE CLOTHING.

SAFETY SHOHER AND EYE BATH.

USE ONLY IN A CHEMICAL FUME HOOD.

FACESHIELD (8-INCH MINIMUM).

DO NOT BREATHA DUST.

DO NOT GET IN EYES, ON SKIN, ON CIOTHING.

AVOID PROLONGED OR REFEATED EXPOSURE.

READILY ABSORBED THROUGH SKIN.

WASH THOROUGHLY AETER HANDLING.

TOXIC.

CORROSIVE.

KEEP TIGHTLY CLOSED.

EXTREMELY HYGROSCOPIC

AIR SENSITIVE

STORE IN A COOL DRY PLACE.

SECTION 9. - - - - - - RHYSICAL AND CHEMICAL PRORERTIZS - - - - APPRARANCE AND ODOR

WHITE PE:LLETS

MELTING POINT: $318 \mathrm{C}$

VAPOR RRISSURE: $\quad 18 \mathrm{MM} 20 \mathrm{C} \quad 3 \mathrm{MM} 37 \mathrm{C}$

VAPOR DEIVSITY: $>1$

SPECIEIC GRAVITY: 2.130

SECTION 10. - - - - - - - STABILITY AND REACTIVITY - - - - - -

INCOMPATIBILITIES

STRONG OXIDIZING AGENTS

STRONG ACIDS

ORGANIC MATERIAIS

CHLORINATED SOLVENTS

ABSORES CO2 PROM AIR.

PROTECT FROM MOISTURE.

HAZARDOUS COMBUSTION OR DECOMPOSITION PRODUCTS

NATURE OF DECOMPOSITION PRODUCTS NOT XNOWN.

TION 11. . - - - - - - TOXICOLOGICAL INFORMATION - - - - -

Page 2

B-2 
HNF-SD-RE-TPI-002, Rev. 0

ar $788 / 96 \quad 22: 47: 32$

$1-589-376-2128->$

5893769964

Page 923

Product \#: So899 Name: SODIUM HYDROXIDE PELIETS ACS REAGENT
Material Safety Data Sheet Valid 2/95-4/95
printed: 02/22/1995 $15: 33: 43$

ACUTE EFFECTS

MSDS \#045620

HARMEUI, IE SWALLOWED, INHALED, OR ABSORBED THROUGH SKIN.

MATERIA.I IS EXTREMELY DESTRUCIIVE TO TISSUE OE THE MUCOUS MEMERANES

AND UPEER RESPIRATORY TRACT, EYES AND SKIN.

CAUSES SEVBRE BURNS.

INHALATION MAY BE FATAL AS A RESULT OF SFASM, IIVLFMAATION AND SDEMA

OF THS LARYNX AND BRONCHI, CHEMICAL PNEUTONITIS MSD FULHONARY EDEMA. SYMPTOMS OF EXPOSURE MAY INCLUDE BURNING SENSATION, COUGHING,

WHEEZING, LARYNGITIS, SHORTNESS OF EREATH, HEADACHE, NAUSEA AND

VOMITING.

TO TUB BEST OF OUR KNOWLEDGE, TKE CHEMICAL, PHYSICAI, ZND

IOXICOLOGICAL PROPERTIES HAVE NOT BEEN THOROUGHLY INVESTIGATED.

RTECS NO: SODIUM HYDROXIDE

IRRITATION DATA

EYE-MKY 1\&/24H SEV

$S K N-R B I 500 \mathrm{MG} / 24 \mathrm{H} \mathrm{GEV}$

IYE-RET 400 UG MLD

EYE-RET Iक SEV

EYE-RBT 50 UG/24H SEV

EYE-RBT I MG/24H SEV

EYE-RBT I MG/3OS RINSE SEV

ICITY DATA

IFR-MUS ID50:40 MG/KG

TXAPA9 $6,701,64$

$28 Z$ PAK $-, 7,72$

OYYAA2 $26,627,83$

AJOPAA $29,1363,46$

$28 Z \mathrm{PAK} \rightarrow, 7,72$

TXAPA9 $6,701,64$

TXCYAC $23,281,82$

ONLY SEIECTED REGISTRY OF TOXIC EEEECTS OF CHEMICAL SUBSIANCES

(RTECS) DATA IS PRBSBNTBD HERE. SBE ACTUAL BNTRY IN RTECS EOR COMPLETE INFORMATION.

SECTION 12 . - - - - - - - ECOLOGICAL INEORMATION - - - - - - -

DATA NOT YET AVAILAELE.

SECIION 13 . - - - - - - - - DISPOSAI CONSIDERATIONS - - - - - - FOR SMALL QUANTITIES: CAUTIOUSLY ADD TO A TARGE STIRRED EXCESS OF WATER. ADJUST THE PH TO NSUTRAL, SEPARATE ANY INSOLUBLE SOLIDS OR LIQUIDS AND FACKAGE THEM FOR HAZARDOUS-WASTE DISPOSAL. FLUSH THE AQUBOUS SOLUTION DOWN THE DRAIN WITA PLENTY OF WATER. THE MYDROIYSIS AND NEUTRALIZATION REACTIONS MAY GENERATZ HEAT AND FUMES WHICH CAN BE CONTROLLED BY THE RATE OF ADDITION.

OBSERVE ALL FEDERAL, STATE AND LOCAL ENVIRONMENTAL REGULATIONS.

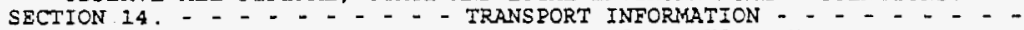
CONTACT SIGMA CHEMICAL COMPANY FOR TRANSPORTATION INFORMATION.

SECTION 15. - - - - - - - REGULATORY INEORMATION - - - - - - - RBVISAS, STANDARDS, AND REGULATIONS

ACGIH TLV-CL $2 \mathrm{MG} / \mathrm{M} 3$

85 INA8 $6,1416,91$

EPA FIFRA 1988 FESTICIDE SUBJECT TO REGISTRATION OR RE-REGISTRATION

FEREAC $54,7740,89$

MSHA STRNDAFD:AIR-CL, $2 \mathrm{MG} / \mathrm{M} 3$

DTLVS $* 3,233,71$

OSHA DEL: $8 \mathrm{H}$ TWA $2 \mathrm{MG} / \mathrm{M} 3$

FEREAC $54,2923,89$

OSHA PEL FINAL:CI $2 \mathrm{MG} / \mathrm{M} 3$

Page 3 
HNF-SD-RE-TPI-002, Rev. 0

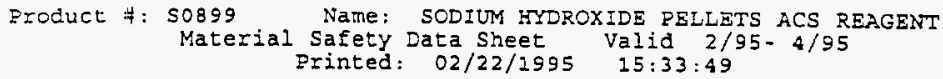


HNF-SD-RE-TPI-002, Rev. 0

$9 / 4689: 815: 47$

SUBSTANCE: IIYDROELUORIC ACID REAGENT ACS

CAS-NUMBER 7664-39-3

TRADE NAMES/SYNONYMS :

MSDS $\$ 039275$

FLUORIC ACID; HYDROFLUORIC ACID SOLUTION; UN $1790 ;$ RCRA U134; IIF; OIISI1172

CHEMICAL FAMILY:

INORGANIC ACID

MOLECULAR FORMULA: II-F

CERCLA RATINGS (SCALE 0-3): IIEALTI=3 FIRE=0 REACTIVITY=1 PERSISTENCE=0 NIPA RATINGS (SCALE 0-4): IIEALTI $=4$ FIRE $=0$ REACTIVITY $=1$

COMPONENTS AND CONTAMINANTS

COMPONENT: IIYDROGEN FLUORTDE

COMPONENT: WATER

EXPOSURE LIMITS:

HYDROGEN FLUORIDE, AS F:

3 FPM OSIIA THA; 6 PPH OSIIA STEL

PPM $(2.5 \mathrm{HG} / \mathrm{M3})$ ACGIII CEILING

PPM (2.5 MG/M3) NIOSII RECOWHENDED 10 IIOUR TWA;

6 PPH ( $5 \mathrm{MG} / \mathrm{M} 3$ ) NIOSH RECOMKENDED 15 MINUTE CEILING

100 POUNUS SARA SECTION 302 TIRESIIOLD PLANNING QUANTITY

100 POUNLS SARA SECTION 304 REPORTABLE QUANTITY

100 POUNDS CERCLA SECTION 103 REPORTABLE QUANTITY

SUBJECT TO SARA SECTION 313 ANNUAL TOXIC CIIEMICAL RELEASE REPORTING

\section{PIIYSICAL DATA}

DESCRIPTION: COLORLESS TO SLIGHTLY YELLOW LIQUID WITH A PUNGENT ODOR. BOILING POINT: $225 \mathrm{~F}(107 \mathrm{C})$ HELTING POINT: $-35 \mathrm{~F}(-37 \mathrm{C})$ (APPROX.) SPECIFIC GEAVITY: $1.15-1.18$ VAPOR PRESSURE: 25 MHHG $€ 2 O C$ PII: <2 SOLUBILITY IN WATER: SOLUBLE
PERCENT: 49.0

PERCENT: 51.0 
HNF-SD-RE-TPI-002, Rev. 0

E $9 / 96 \quad 89: 07: 22$

$1-589-376-2128->$

5893769964

Page 893

PAGE 02 OF OB

TIRE AND EXPLOSION IYAZARD:

VIGLIGIBLE FIRE IIAZARD WHEN EXPOSED TO IIEAT OR TLAME.

\section{NSDS $* 1039275$}

TIREFIGHTING MEDIA:

DRY CIIEMICAL, CARDON DIOXIDE, HALON, WATER SPRAY OR ALCOIIOL FOAM

(I987 EHERGEISCY RESPONSE GUIDEDOOK, DOT P 5800.4).

FOR LARGER FIRES, USE WATER SPRAY, FOG OR STANDARD FOAH

(1987 EMERGENCY RESPONSE GUIDEBOOK, DOT P 5800.4).

TIREFIGIITING :

MOVE CONTAINERS FROM FIRE AREA IF POSSIDLE. COOL CONTAINERS EXPOSED TO FLAMES WITH WATER FROM SIDE UNTIL WELL AFTER FIRE IS OUT. STAY AHAY FROM STORAGE TANK ENDS (1987 EMERGENCY RESPONSE GUIDEDOOK, DOT P 5800.4, GUIDE PAGE 59).

DO NOT USE WATER ON MATERIAL. EXTINGUISI USING AGENTS SUITABLE FOR TYFE OF FIRE, USE ELOODING AMOUNTS OF WATER AS FOG. COOL CONTAINERS WITH FLOODING AMOUNTS OF WATER, APPLY FROM AS FAR A DISTANCE AS POSSIBLE. AVOID BREATHING CORROSIVE VAPORS, KEEP UPWIND.

\section{TRANSPORTATION DATA}

RTMENT CF TRANSPORTATION HAZARD CLASSIFICATION 49CFR172.101:

CORROSIVE MATERIAL

DEPARTMENT OF TRANSPORTATION LABELIHG REQUIREMENTS 49CERI72.101 AND SUDPART E: CORROSIVE

DEPARTMENT OF TRANSPORTATION PACKAGINO REQUIREMENTS: 49CFR173.264

EXCEPTIONS : 49CFR173.244

TOXICITY

KYDROGEN FLUORIDE:

50 MG EYE-IIJMAN SEVERE IRRITATION; $100 \mathrm{MG} / 33 / 1$ MINUTE INHALATION-MAN TCLO;

50 PPM/30 MINUTES INHALATION-HUMAN LCLO; 1276 PPM/1 HOUR INIIALATION-RAT LC50;

342 PPM/1 IDOUR INHALATION-MOUSE LC50; 1774 PQM/1 HOUR INKALATION-KONKEY LC50;

$260 \mathrm{KG} / \mathrm{M3} / 7$ HOURS INHALATION-RADDIT LCLO; 4327 PPM/15 MINUTES

INIIALATION-GUINEA PIG LC50; $500 \mathrm{MG} / K G$ SKIN-MOUSE LDLO; $25 \mathrm{MG} / \mathrm{KG}$

INTRAPERITONEAL-RAT LDLO; MUTAGENIC DATA (RTECS); REPRODUCTIVE EFFECTS DATA

(RTECS).

CARCINOGEN STATUS: NONE.

IIYDROGEN FLUORIDE IS TOXIC AND A SEVERE EYE, SKIN AND MUCOUS MEMBRANE

IRRITANT. CHRONIC EXPOSURE MAY PRODUCE FLUOROSIS OF THE SKELETAL SYSTEM.

HEALTH EFFECTS AND EIRST AID

INIIALATION:

IYYDROGEN FLUORIDE:

CORROS IVE/TOXIC. 30 PPM IMMEDIATELY DANGEROUS TO LIEE OR IIEALTII.

- CUTE EXFOSURE- TWO IIUHAN SUDJECTS EXPOSED TO 120 PPH EXPERIENCED MARKED RESPIRATORY IRRITATION. TIIS WAS THE HIGHEST CONCENTRATION THAT COULD DE TOLERATED FOR MORE THAN ONE MINUTE, 30 PPY CAUSED MILD NASAL IRRITATION 
HNF-SD-RE-TPI-002, Rev. 0

79/36 89:68:17

1-589-376-2129->

5893769964

Page 364

\section{MSDS \# 03927.5}

PAGE O3 OF 08

AND COULD BE TOLERATED FOR SEVERAL MINUTES. HIGIIER CONCENTRATIONS MAY CAUSE TRANSIENT CHOKING, COUGIING, CIILLS, CIIEST PAIN AND CONSTRICTION, AND DYSPNEA. AN ASYMPTOMATIC PERIOD OF 12-48 HOURS MAY BE FOLLOWED BY FEVER, COUGII, DYSPNEA, CYANOSIS, RALES, AND FULMONARY EDEMA OR BRONCHIAL PNEUMONIA. IN HUMANS, KIDNEY DAMAGE HAS ONLY BEEN REPORTED IN SEVERE, ACUTE OVEREXPOSURES. IN FOUR SEPARATE EVENTS, 9 WORKERS WERE SPLASIITD WITII IIYDROFLIJORIC ACID; 6 DTED. DEATII OCCURRED 2-10 HOURS AFTER EXPOSURE AND WAS CAUSED BY PULHONARY EDEHA, IIEMORRHAGIC PULHONARY EDEMA AND ULCERATIVE TRACHEOBRONCHITIS, OR CARDIAC ARREST. IN ONE INSTANCE, THE DREATIING ZONE CONCENTRATION WAS ESTIMATED TO BE ABOVE 10,000 PPH.

CHRONIC EXPOSURE- 5 HUMAN SUBJECTS EXPOSED 6 IIOURS/DAY, 5 DAYS/WEEK, FOR 10-50 DAYS AT AVERAGE CONCENTRATIONS OF UP TO 4.7 PPM EXPERIENCED SIIGIIT NASAL IRRITATION. REPEATED EXPOSURE TO LOW CONCENTRATIONS MAY CAUSE NASAL CONGESTION, NOSEBLEEDS, SINUS PROBLEMS, AND BRONCIITIS. ABSORPTION OF EXCESSIVE AMOUNTS OF FLUORINE MAY RESULT IN FLUOROSIS, A SYNDROKE CIIARACTERIZED BY OSTEOSCLEROTIC DONE CIANGES. CASES OF VARYING DEGREES OF OSTEOSCLEROSTS ITAVE BEEN REPORTED IN WORKERS EXPOSED TO HYDROGEN FLUORIDE TOR A NUMBER OF YEARS, USUALLY 3 OR MORE. THE EIRST EVIDENCE OF CIIANGE IS MOST APPARENT IN THE PELVIS AND LUMBAR SPINE AND MAY BE ACCOMPANIED BY MILD TO MODERATE BACK PAIN AND STITFNESS. PRESUMADLY, OTIITR SYMPTOMS OF FLUOROSIS, WEIGHT LOSS, GENERAL ILL HEALTII, ANEMIA, BRITTLENESS OF TIIE BONIS, AND DISCOLORATION OF DEVELOPING TEETH, ARE ALSO POSSIBLE. ANIMAL STUDIES INDICATE THAT REPEATED EXPOSURE MAY CAUSE PULMONARY, HEPATIC AND RENAL TISSUE DAHAGE. EXPOSURE OF PREGNANT RATS FOR 22 DAYS FESULTED IN IN EFFECTS ON FERTILITY AND ON THE FETUS.

CST AID- REMOVI FROM EXPOSURE AREA TO FRESII AIR IMMEDIATELY. IF BREATHING IIAS STOPPED, GIVE ARTIFICIAL RESPIRATION. MAINTAIN AIRWAY AND BLOOD PRESSURE AND ADMINISTER OXYGEN IF AVAILADLE. KEEP AFFECTED PERSON WARM AND AT REST. TREAT SYMPTOMATICALLY AND SUPPORTIVELY. ADMINISTRATION OF OXYGEN SIIOULD BE PERFORHED BY QUALIFIED PERSONNEL. GET MEDICAL ATTENTION

IMMEDI ATELY.

SKIN CONTACT:

HYDROGEN TLUORIDE:

CORROSTVE.

ACUTE EXPOSURE- IYYDROGEN FLUORIDE DURNS ARE CIIARACTERIZED DY A BLANCHED APPEARANCE OF TIIE SKIN WITH PERSISTENT EXCRUCIATING PAIN, EDEMA AND NECROSIS. WITII CONCENTRATIONS LESS TIIAN 2O\%, PAIN AND ERYTHEHA MAY OCCUR AFTER A LATENT PERIOD OF 24 HOURS. WITH 20-50X SOUUTIONS, BURNS MAY BE AFPARENT WITHIN 1-8 HOURS. WITII CONCENTRATIONS GREATER THAN 50\%, IMMEDTATE PAIN AND RAPIDLY APPARENT TISSUE DAHAGE OCCUR ON CONTACT, SMALL AMOUNTS OF HYDROGEN FLUORIDE WIIICII ARE NOT WASHED OFF HAY CAUSE DELAYED DEVELOPMENT OF NON-HEALING ULCERS. FINGERNAILS AND NAIL BEDS MAY BE COMPLETELY DESTROYED. PENETRATION OF TIIE FLUORIDE ION TO DEEP TISSUES HAY RESULT IN SLOW HEALING NECROSIS OF SOFT TISSUES AND DECALCIFICATION OF BONE. VAPORS AT A CONCENTRATION OF OF 120 PPM CAUSED SMARTING OF EXPOSED SKIN IN PEOPLE IN ONE MINUTE. SYSTEMIC FLUORIDE POISONING THROUGH SKIN ABSORPTION MAY OCCUR. STUPOR, UNRESPONSIVENESS TO STIMULI OTHER THAN PAIN, SEVERE NAUSEA, VOMITING, AND REDUCED PULSE RATE WERE REPORTED IN ONE CASE.

CIIRONIC EXPOSURE- REPEATED OR PROLONGED EXPOSURE HAY CAUSE IRRITATION OR BURNS. SLIGIT IRRITATION OCCURRED IN PEOPLE EXPOSED TO VAPOR

CONCENTRATIONS AVERAGING 2.5 AND 4.7 PRK FOR PERIODS OF UP TO 50 DAYS. SLIGIIT IESQUAMATION OF TIEE SUPERTICIAL EPITIELIUM OF TIE FACE WAS OBSERVED IN ONE SUBJECT AETER TEN DAYS OF EXPOSURE TO HYDROGEN FLUORIDE AT 3.4 PPH. 
FIRST AID- REMOVE CONTAMINATED CLOTIING AND SHOES IMMEDIATELY. WASH AFFECTED AREA WITI SOAP OR MILD DETERGENT AND LARGE AMOUNTS OF WATER UNTIL NO EVIDENCE OF CHEHICAL REMAINS (AT LEAST 15-20 MINUTES). IN CASE OF CHEHICAL BURNS, COVER AREA WITII STERILE, DRY DRESSING, DANDAGE SECURELY, DUT NOT TOO TIGHTLY. GET MEDICAL ATTENTION IMMEDIATELY.

EYE CONTACT :

IIYDROGEN FLUORIDE:

CORROSIVE.

ACUTE EXPOSURE- EXPOSURE TO IIYDROGEN FLUORIDE AVERAGING 4.7 PPH FOR 6 HOURS, OF: 30 PPM FOR SEVERAL MINUTES CAUSED MILD IRRITATION, WHILE 120 PPM RESULTED IN MARKED CONJUNCTIVAL IRRITATION WITIIIN 1 HINUTE IN HUMANS. IIIRECT CONTACT WITH THE LIQUID OR SOLUTIONS MAY CAUSE CORNEAL BURNS. IF NOT PROMPTLY REMOVED, PERHANENT VISUAL DEFECTS OR BLINDNESS MAY RESULT. ONE WORKER EXPOSED TO A FINE SPRAY OF CONCENTRATED HYDROGEN FLUORIDE, HAD LOSS OF EPITHELIUM FROM THE CORNEA AND CONJUNCTIVA, AND MARKED EDEMA OF THE EYELIDS, CONJUNCTIVA, AND CORNEAS; PROMPT TREATYENT WAS ADMINISTERED. NORMAL VISION WAS REGAINED WITIIIN 19 DAYS.

CIIRONIC EXPOSURE- HUMANS EXPERIMENTALLY EXPOSED TO CONCINTRATIONS HHICII AVERAGED 2.6-4.7 PPM FOR UP TO 50 DAYS DEVELOPED MILD EYE IRRITATION. IN ANIMALS, REPEATED OR PROLONGED EXPOSURE TO LOW VAPOR CONCENTRATIONS CAUSED SLIGHT LACRIMATION.

+. $r$ AID- WASH EYES IMMEDIATELY WITH LARGE AMOUNTS OF WATER, OCCASIONALLY - SING UPFER AND LONER LIDS, UNTIL NO EVIDENCE OF CHEMICAL REMAINS (AT LEAST 15-20 MINUTES). CONTINUE IRRIGATING WITH NORMAL SALINE UNTIL TIIE PI IIAS RETURNED TO NORMAL $(30-60$ MINUTES). COVER WITH STERILE BANDAGES. GET MEDICAL ATTENTION IMMEDIATELY.

INGESTION :

HYDROGEN FLUORIDE:

CORROSIVE.

ACUTE EXPOSURE- INGESTION HAY CAUSE BURNS OF TIIE MOUTH, ESOPIIAGUS, STOMACH AND SMALI, INTESTINE WITH GASTRITIS, GASTRIC IIEMORRHAGES, VOMITING, NAUSEA, ADDOHINAL PAIN, AND DIARRHEA. LARGE DOSES MAY CAUSE EXTENSIVE NECROSIS WITH PERFORATION OF TIIE STOMACII, SIIOCK AND DEATII, SYSTEKIC POISONING HAY CAUSE IIYPOGLYCEMIA, IIYPERKALEMIA, HYPOMAGNESEMIA, AND SEVERE HYPOCALCEMIA RESULTING IN TETANY, ESPECIALLY OF THE EXTREMITIES, AND PARESTHESIAS . HYPOTENSION, CIRCULATORY SIOCK AND CARDIAC ARRIYTHMIAS INCLUDING SINUS TACHYCARIIA OR VENTRICULAR FIDRILLATION, SOMETIMES PRECEDED BY TACIIYCARIIA, MAY OCCUR. CENTRAL NERVOUS SYSTEM SYMPTOHS MAY INCLUDE HEADACHE, EXCESSIVE SALIVATION, NYSTAGMUS AND DILATED PUPILS, LETHARGY, STUPOR, COMA, AND RARELY, TRANSIENT CONVULSIONS. DEATII IS USUALLY DUE TO RESPIRATORY PARALYSIS OR CARDIAC FAILURE. IN NON-FATAL CASES, JAUNDICE AND KIDNEY DAMAGE WITH ALBUMINURIA, IIEMATURIA, OLIGURIA OR ANURIA MAY OCCUR, DUT ARE GENERALLY REVERSIBLE. ASPIRATION HAY LEAD TO CHEMICAL PNEUMONITIS. CHRONIC EXFOSURE- CIIRONIC INGESTION OF SMALL AMOUNTS MAY CAUSE FLUOROSIS WITH OSTEOSCLEROTIC THICKENING WITH CALCIFICATION IN LIGAHENTOUS ATTACHMENTS OF SKELETON, WEIGHT LOSS, BRITTLENESS OF DONES, REDUCED DONE MARIIOW SPACE WITH ANEMIA, WEAKNESS, GENERAL ILL HEALTH, STIFFNESS OF JOINTS, AND DISCOLORATION OF DEVELOPING TEITH. RARELY, CENTRAL NERVOUS SYSTEM INVOLVEMENT OCCURS.

FIRST AID- DO NOT USE GASTRIC LAVAGE OR EMESIS. DILUTE THE ACID IMMEDIATELY DRINKING LARGE QUANTITIES OF WATER OR YILK. IF VOMITINO PERSISTS, M MINISTER FLUIDS REPEATEDLY. INGESTED ACID MUST BE DILUTED APPROXIMATELY 
HNF-SD-RE-TPI-002, Rev. 0

r. $29 / 36 \quad 89: 18: 59$

$1-599-376-2128->$

5893769964

Page 800

100 PAGE 05 OF 08 100 FOLD TO RENDER IT IIARMLESS TO TISSUES. MAINTAIN AIRWAY AND TREAT SHOCK (DREISBACI, IIANDBOOK OF POISONING, 12TH ED.). QET MEDICAL ATTENTION IMKEDIATELY. IF VOMITING OCCURS, KEEP HEAD BELOW HIPS TO UIELP PREVINT ASPIRATION.

ANTIDOTE:

MSDS \#.039275

NO SPECIFIC ANTIDOTE. TREAT SYMPTOMATICALLY AND SUPPORTIVELY.

REACTIVITY

REACTIVITY:

REACTS EXOTHERMICALLY WITH WATER OR STEAM WITH THE RELEASE OF TOXIC AND CORROSIVE FUMES.

INCOMPATIBILITIES:

IIYDROGEN FLUORIDE:

ACETIC ANIYDRIDE: TEMPERATURE AND PRESSURE INCREASE IN A CLOSED CONTAINER.

2-AMINOETIIANOL: TEMPERATURE AND PRESSURE INCREASE IN A CLOSED CONTAINER.

AMMONIUM HYDROXIDE: TEHPERATURE AND PRESSURE INCREASE IN A CLOSED CONTAINER.

ARSENIC TRIOXIDE: INCANDESCENT REACTION.

BISMUTHIC ACID: VIOLENT REACTION EVOLVING OZONISED OXYGEN.

CALCIUM OXIDE: VERY VIOLENT REACTION HITII INCANDESCENCE.

CIILOROSULTURIC ACID: TEMPERATURE AND PRESSURE INCREASE IN A CLOSED CONTAINER.

OATINGS: ATTACKED.

NACRETE: ATTACKED.

CYANOGEN ELUORIDE: EXPLOSIVE POLYMERIZATION RTACTION.

DIPIIOSPIIOROUS PENTOXIDE: YIOLENT REACTION,

ETIYLENEDIAYINE: TEMPERATURE AND PRESSURE INCREASE IN A CLOSED CONTAINIR.

ETHYLENEIMINE: TEMPERATURE AND PRESSURE INCREASE IN A CLOSED CONTAINER.

FLUORINE: ENERGETIC REACTION WITH IGNITION.

GLASS: ATTACKED.

LEATIER: ATTACKED.

METALS: MAY GENERATE FLAMMABLE IIYDROGEN GAS UPON CONTACT,

MERCURY OXIDE: EXOTHERMIC REACTION UNLESS ADEQUATE COOLING KEEPS REACTION TEMPERATURE BELOW O C.

HETHANESULFONIC ACID: ELECTROLYSIS OF A MIXTURE PRODUCED OXYGEN DIFLUORIDE WIIICII EXPLODED.

NITRIC ACID: IGNITION.

NITRIC ACID + GLYCEROL: TEMPERATURE AND PRESSURE INCREASE IN A CLOSED CONTAINER.

NITRIC ACID + LACTIC ACID: UNSTABLE MIXTURE.

NITRIC ACID, PROPYLENE GLYCOL, AND SILVER NITRATE: UNSTABLE MIXTURE.

OLEUM: TEMPERATURE AND PRESSURE INCREASE IN A CLOSED CONTAINER.

ORGANIC MATERIALS: ATTACKED.

N-PHENYLAZOPIPERIDINE: VIOLENT REACTION.

PHOSPHORUS(V) OXIDE: VIGOROUS REACTION BEIOW $20 \mathrm{C}$.

PLASTICS: ATTACKID.

POTASSIUM PERMANGANATE: VIOLENT, EXOTHERMIC REACTION WITH CONCENTRATED ACID. POTASSIUM TETRAFLUORISILICATE: VIOLENT EVOLUTION OF SILICON TETRAFLUORIDE.

PROPIOLACTONE (BETA): TEMPERATURE AND PRESSURE INCREASE IN A CLOSED CONTAINER.

PROPLYLENE OXIDE: TEMPERATURE AND PRESSURE INCREASE IN A CLOSED CONTAINER. RUBBER (NATURAL): ATTACKED.

SILICA CONTAINING MATERIALS: CORROSIVE.

TDIUM: REACTS WITII EXPLOSIVE VIOLENCE WITII AQUEOUS ACID.

SDIUM HYDROXIDE: TEMPERATURE AND PRESSURE INCREASE IN A CLOSED CONTAINER. 
HNF-SD-RE-TPI-002, Rev. 0

r. $29 / 36$ 89:11:59

.

PAGE 06 OF 08 IN A CLOSED CONTAINER. TETRAFLUOROSILICIC ACID: VIOLENT REACTION.

VINYL ACETATE: TEMPERATURE AND PRESSURE INCREASE IN A CLOSED CONTAINER. DECOMFOSITION : THITMAL DECOMPOSITION MAY RELEASE CORROSIVE IIYDROGEN FLUORIDE. TEMPERATURES AND PRESSURES. OF TIIS SUBSTANCE. FOR ASSISTANCE, CONTACT THE DISTRICT DIRECTOR OF THE ENVIRONMENTAL FROTECTION AGENCY.

\section{**STORAGE**}

PROTECT AGAINST PHYSICAL DAMAGE. STORE IN WELL-VENTILATED AREA, SEPARATED FROM OTHER STORAGE (NFPA 49, IHAZARDOUS CHEMICALS DATA, 1975).

STORE AWAY FROM INCOMPATIBLE SUBSTANCES.

\section{**DISPOSAL**}

DISPOSAL MUST BE IN ACCORDANCE WITII STANDARDS APPLICABLE TO GENERATORS OP HAZARDOUS WASTE, 40 CFR 262. EPA HAZARDOUS WASTE NUMBER DO02.

100 POUND CERCLA SECTION 103 REPORTADLE QUANTITY.

\section{CONDITIONS TO AVOID}

MAY BURN DUT DOES NOT IGNITE READILY. MAY IGNITE COMBUSTIBLES (WOOD, PAPER, OIL, ETC.).

\section{SPILL AND LEAK PROCEDURES}

SOIL SPILL:

DIG IIOLDING AREA SUCII AS LAGOON, POND OR PIT FOR CONTAINMENT.

DIKE FLOW OF SPILLED MATERIAL USING SOIL OR SANDBAGS OR FOAMED BARRIERS SUCH AS POLYURETHANE OR CONCRETE.

USE CEMENT POWDER OR ELY ASH TO ADSORB LIQUTD MASS.

NEUTRALIZE SPILL WITH SLAKED LIME, SODIUM BICARDONATE OR CRUSHED LIMESTONE. $\therefore$ 
HNF-SD-RE-TPI-002, Rev. 0

r $3 / 96 \quad 99: 12: 42$

1-589-376-2128->

5893769964

Page 8Ed

$\therefore$

-ater spill:

PAGE 07 OF 08

NEUTRALIZE WITH AGRICULTURAL LIME, SLAKED LIME, CRUSIIED LIMESTONE, OR SODIUM BICARBONATE.

NEUTRALIZE WITH CAUSTIC SODA.

MSDS $: 039225$

ADD SUITABLE AGENT TO NEUTRALIZE SPILLED MATERIAL TO PH-7.

USE MECILNICAL DREDGES DR LIFTS TO EXTRACT IMMOBIIIZED MASSES OF POLLUTION AND PRECIPITATES.

OCCUPATIONAL SPILL:

DO NOT TOUCH SPILLED MATERIAL. STOP LEAK IE YOU CAN DO IT WITHOUT RISK. USE WATER SPRAY TO REDUCE VAPORS. FOR SHALL SPILLS, TAKE UP WITH SAND OR OTIER ADSORDENT MATERIAL AND ?LACE INTO CONTAINERS FOR LATER DISPOSAL. FOR LARGER SPILLS, DIKE SPILL FOR LATER DISPOSAL. KEEP UNNECESSARY PEOPLE AWAY. ISOLATE HAZARD AREA. AND DENY ENTRY.

PROTECTIVE EQUIPMENT

VENTILATION :

PROCESS ENCLOSURE RECOMMENDED TO MEET PUDLISHED EXPOSURE LIMITS.

RESPIRATOR:

- FOLLOWING RESPIRATORS AND MAXIMUY USE CONCENTRATIONS ARE RECOMMENDATIONS ,Y THE U.S. DEPARTMENT OF HEALTH AND HUMAN SERVICES, NIOSH POCKET GUIDE TO CHEMICAL IIAZARDS; NIOSII CRITERIA DOCLMENTS OR BY TIIE U.S. DEPARTMENT OF LABOR, 29 CFR 1910 SUDPART $Z$.

THE SPECIFIC RESPIRATOR SELTCTED MUST BE BASID ON CONTAMINATION LIVELS FOUND IN TIIE WCRK PLACE, MUST KOT EXCEED THE WORKING LIMITS OF TIIE RESPIRATOR AND BE JOINTLY APPROVED BY THE NATIONAL INSTITUTE FOR OCCUPATIONAL SAFETY AND HEALTH AND THE MINE SAEETY AND HEALTII ADHINISTRATION (NIOSH-MSHA).

HYDROGEN FLUORIDE:

30 PPM- ANY SUPPLIED-AIR RESPIRATOR

ANY SELF-CONTAINED DREATHING APPARATUS.

ANY POWERED AIR-PURIFYING RESPIRATOR HITH CARTRIDGE(S) PROVIDING FROTECTION AGAINST HYDROGEN FLUORIDE.

ANY CHEMICAL CARTRIDGE RESPIRATOR WITII CARTRIDGE(S) PROVIDING FROTECTION AGAINST HYDROGEN FLUORIDE.

ANY AIR-PURITYING FULL FACEPIECE RESPIRATOR (GAS MASK) WITH A CHIN-STYLE OR FRONT- OR BACK-MOUNTED CANISTER PROVIDING PROTECTION AGAINST HYDROGEN FLUORIDE.

ESCAPE- ANY AIR-PURIFYING TULL FACEPIECE RESPIRATOR (GAS MASK) WITH A CHIN - STYLE OR FRONT- OR BACK-MOUNTED CANISTER PROVIDING FROTECTION AGAINST HYDROGEN FLUORIDE.

ANY APPROPRIATE ESCAPE-TYPE SELF-CONTAINED BREATHING APPARATUS.

FOR FIREFIGHTING AND OTHER IMMEDIATELY DANGEROUS TO LIFE OR IIEALTII CONDITIONS:

SELF-CONTAINED BREATHING APPARATUS WITH FULL FACEPIECE OPERATED IN PRESSURE-DEMAND OR OTIIER POSITIVE PRESSURE MODE.

UPPLIED-AIR RESPIRATOR WITU FULL TACEPIECE AND OPERATED IN PRESSURE-DEMAND OR OTIER POSITIVE PRESSURE MODE IN COMBINATION WITII AN AUXILIARY 
HNF-SD-RE-TPI-002, Rev. 0

PAGE 08 OF 08

SELF-CONTAINED BREATHING APPARATUS OPERATED IN PRESSURE-DEMAND OR OTHER POSITIVE PRESSURE MODE.

\section{CLOTHING :}

\section{MSDS \#. 03.227 .5}

EMPLOYEE NUS' WEAR APPROPRIATE PROTECTIVE (IMPERVIOUS) CLOTHING AND EQUIPMENT TO PREVENT ANY POSSIBILITY OF SKIN CONTACT HITH THIS SUBSTANCE.

GLOVES :

EMPLOYEE HUST WEAR APPROPRIATE PROTECTIVE GLOVES TO PREVENT CONTACT WITII TIIS SUBSTANCE.

EYE PROTECTION:

EMPLOYEE MUS'T WEAR SPLASII-PROOF OR DUST-RESISTANT SAFETY GOGGLES AND A FACESHIELD TO PREVENT CONTACT WITH THIS SUBSTANCE.

EMERGENCY WASH FACILITIES:

WHERE THERE IS ANY POSSIBILITY THAT AN EMPLOYEE'S EYES AND/OR SKIN MAY DE EXPOSED TO THIS SUBSTANCE, TUE EMPLOYER SHOULD PROVIDE AN EYE WASII FOUNTAIN AND QUICK DRENCH SIIOWER WITIIN THE IMHEDIATE WORK AREA FOR EMERGENCY USE.

AUTHORIZED DY- SPECTRUM CIIEMICAL MFG. CORP. CREATION DATE: 03/08/89 REVISION DATE: $11 / 02 / 89$ 
HNF-SD-RE-TPI-002, Rev. 0

S- ECTRUH CIIEMICAL MFG. CORP. $14422 \mathrm{~S}$. San Pedro Street Gardena, CA 90248-9985 Phone: (213) 516-8000
EMERGENCY CONTACT:

CIIEKTREC (800) 424-9300

SPECTRUM TECHNICAL SERVICE (213) 516-8000

NSDS 039275

The statements contained herein are offered for informational purposes only and are intended to be followed only by persons having related technical skills and at their own discretion and risk. Since conditions and manner of use are outside our control, we make no warranties, express or inplied, and no liability in connection with any use of this information. 
HNF-SD-RE-TPI-002, Rev. 0

$29 / 96 \quad 88: 55: 58$

$1-599-376-2128 m$

5893769964

Paye 892

\begin{abstract}
RRODUCT \#: 26759 NAYE: FYIROCHLORIC ACID REAEENT
MATERIAL SAFETY DATA SHEEI, Valid $2 / 96-4 / \mathrm{G}$

Printed Thursiay, Eebruazy 01, 1996 20:50RM
\end{abstract}

Sigma Chemical co. P. 0 . BOX 14508

St. Louis, MO $63: 78$

Fhone: 314-771-5765

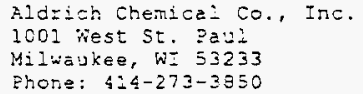

Fluka Chemical corp. g80 scuth second $5 \tau$. Ronkonkoma, NY 11779

Phone: 516-467-0560

Emezgercy phore: 516-467-3535

MSDS 036338

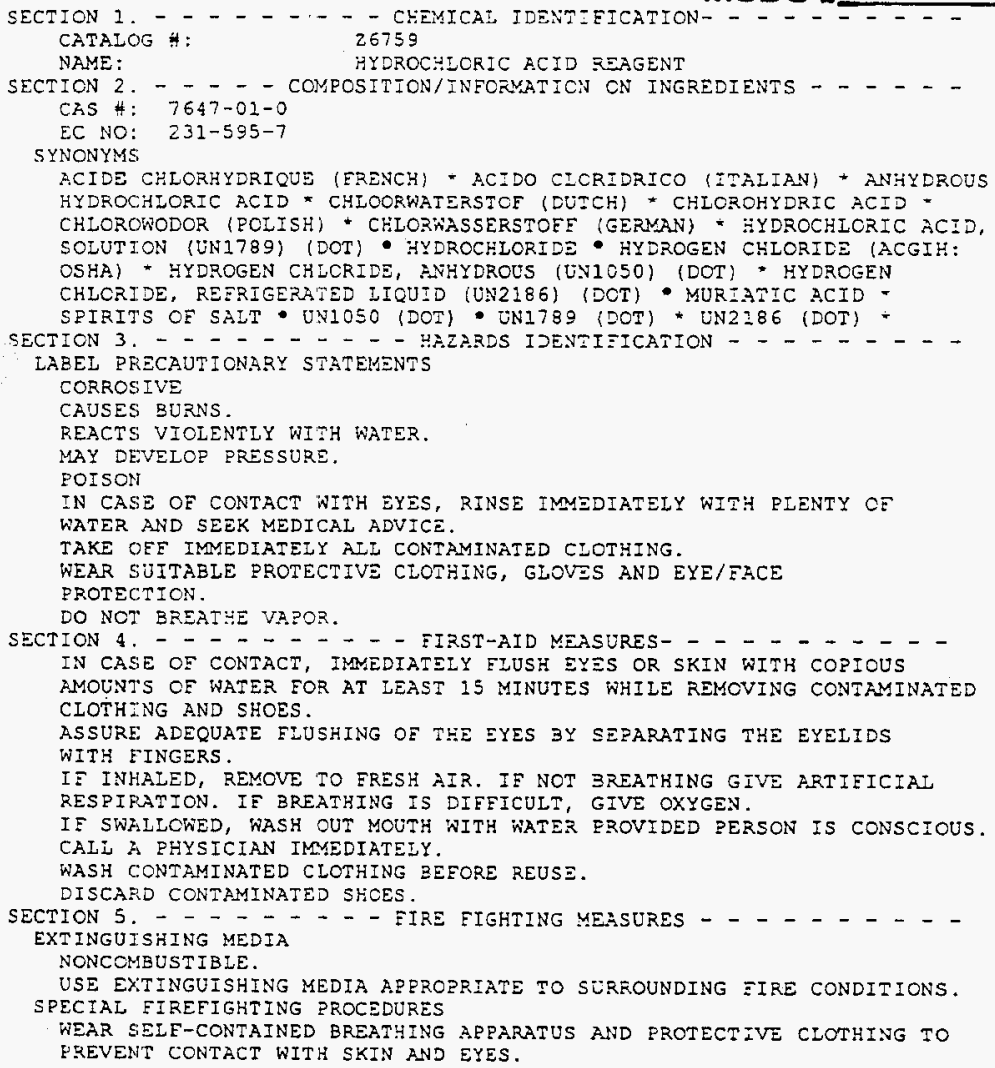


HNF-SD-RE-TPI-002, Rev. 0

$29 / 96 \quad 88: 56: 47$
PRODUCT H: 26759 NAME: HYDROCHLORIC ACID REAGENT MATERIAL SAEETY DATA SHEET, Valid $2 / 96-4 / 96$
Printed Thuzsday, Eebruary 01, 1996 10:50 AM

USE WAIER SPRAY TO COOI FIEE-EXPOSEI CONTAINERS.

UNUSUAL FIRE AND EXPIOSIONS HAZARDS

EMTTS TOXIC FUMES UNDER FIRE CONDITIONS.

036338

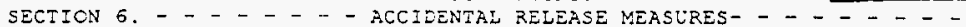
EVACURTE AREA.

WEAR SEIF-CONTAINED BREATHING APEARATUS, RUEEER BOOTS AND HEAVY

RUBBER GLOVES.

COVER WITH DRY-IIME, SAND, OR SODA ASH. PLACE IN COVERED CONTAINERS

USING NON-SPARKING TOOIS AND TRANSPORT OUTDOORS.

VENTILATE AREA AND WASH SPILL SITE AETER MATERIAL FICKUP IS COMELETE.

SECTICN 7 . - - - - - - - HANDIING AND STORAGE- - - $-{ }_{-}-\ldots$ REFER IO SECTION 8 .

SECIEON 8. - - - - - EXROSURE CONTRCLS/PERSONAI PROTECTION- - - - CHEMICAI SAEETY GOGGLES.

SAFETY SHOWER AND EYE BATH.

EACESHIELD (8-INCH MININUM).

NIOSH/MSHA-APPROVED RESPIRATOR IN NCIVENTILATED AREAS AND/CR FOR

EXPOSURE AEOVE THE ACGIH TIV.

MECHANICAL EXHAUST REOUIRED.

RLBBER GLOVES.

AVOID EREATHING VAPOR.

DO NOT GET IN EYES, ON SKIN, ON CLOTHING.

AVOID PROLONGED OR REREATED EXPOSURE.

WASH THOROUGKIY AETER HANDLING.

CORROSIVE.

EOISON

KEEP TIGHTLY CLOSED.

MAY DEVELOP PRESSURE.

REACTS VIOLENTLY WITH WATER.

STORE IN A COOL DRY PIACE.

SECTION 9. - - - - . - PHYSICAL AND CHEMICAL PROPERTIES - - - . -

APPEARANCE AND ODOR

COLORLESS IIQUID

PHYSICAL PRCPERTIES

FLASHPOINT

VAFOR PRESSURE:

SPECIEIC GRAVITY:

VAZOR DENSITY:
SECTION 10. . $^{3}$
-

INCOMPATIBILITIES

BRSES

AMINES

AEKAII METAIS

COPPER, COFZER ALLOYS

AZUMINUM

CORRODES STEEL

SO NOT ALIOW WATER TO ENTER CONTAINER BECAUSE OE VIOIENT REACTION.

HAZARDOUS COMBUSTION OR DECOMPOSITION PRODUCTS

TOXIC FUMES OF:

HYDROGEN CHLORIDE GAS

SECTION 11. - _ - _ - - TOXICOLOGICAI INEORMATION _ _ _ _ .

ACUTE EFEECTS

MAY BE EATAL IE INHAIED, SWALIOWED, OR ABSORBED THROUGH SKIN. CAUSES BURNS.

Fage 2 
HNF-SD-RE-TPI-002, Rev. 0

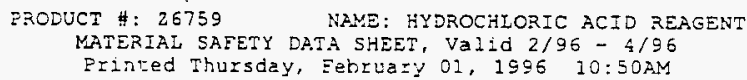

Page 3 
HNF-SD-RE-TPI-002, Rev. 0

ERODUCT \#: 26759 NAME: KYDROCHLORIC ACID REAGENT

MATERIAL SAEETY DATA SHEET, Valid $2 / 96-4 / 96$

Printed Thurstay, February 01, 1996 10:50AM

$5 \quad 23$

DO NOT BEEATHE VAPOR.

REVIENS, STANDARDS, AND REGULAIIONS

OEL=MAK

ACGIH TLV-CL 5 PEM B5INA3 6, 773,92

IARC CANCER REVIEN: IUMAN INAEECUATE EVIEENCE IMEMDE $54,139,92$

IARC CANCER REVIEW:ANIMAI INADEQUATE EVIDENCE IMEMDT 54,189,92

IARC CANCER REVIEN:GROU? 3 IMEMDT 54,189,92

ERA FIFRA 2988 RESTICIDE SUEJECT TO REGISTRATICN OR RE-REGISTPATION EEREAC $54,7740,89$

MSHA STANDARD:AIR-CL 5 PPH (7 MG/MI)

DTLVS * $3,129,71$

OSHA EEL IGEN INDU):CI 5 PPM (7 MG/M3)

CERGER 29,1910.1000,94

OSHA EEI (CONSTRUC):CI 5 PEM (7 MG/M3)

CERGER 29,1926.55,94

OSHA EEI (SHIPYARD):CI 5 RPY (7 MG/M3)

CERGER 29,1915.1000,93

OSHA EEL (FED CONT):CL 5 REM (7 MG/M3)

CERGER 41,50-204.50,94

OEI-ALESIRAIIA: TWA 5 PEM (7 MG/M3) JAN93

OEL-AL"STRIA:TWA 5 PPM (7 MG/M3) JANG3

OEL-BETGIUM: STEL 5 PRM (7.7 MG/M3) JAN93

OEL-DENMARK: STEL 5 PRM (7 MG/M3) JAN93

OEL-FILIAND:STEL 5 PPM $(7 \mathrm{MG} / \mathrm{M} 3)$; SKIN JAN93

CEL-ERANCE:STEL 5 PRM $(7.5 \mathrm{ME} / \mathrm{M} 3)$ JAN93

CEL-GERMANY:TWA 5 PPM (7 MG/M3) JAN93

OEL-HUNGARY: STEL 5 MG/M3 JAN93

CEL-JAPAN:STEL 5 PEM $(7.5 \mathrm{MG} / \mathrm{M3})$ JAN93

CEL-THE NETHERLANDS:TWA 5 PFM (7 MG/M3) JAN93

CEL-THE PHILIPEINES:TWA 5 PPM (7 MG/M3) JAN93

OEL-PCIAAND: TWA $5 \mathrm{MG} / \mathrm{M} 3$ JAN93

OEL-RLSSIA:STEL 5 PEM ( 5 MG/M3) JANG 3

CEL-SWEDEN : STEL 5 PFM (9 MG/M3) JANS3

OEL-SWITZERLAND:TWA 5 FPM (7.5 MG/M3);STEL 10 PPM (15 MG/M3) JAN93

CEL-THAILAND:TWA 5 PFM (7 MG/M3) JAN93

OEL-TURKEY: TWA 5 PQM $(7$ MG/M3) JAN93

CEL-UNITED KINGDOM:TWA 5 PLM (7 MG/M3);STEL 5 PPM (7 MG/M3) JAN93

OEL IN BULGARIA, COLOMBIA, JORDAN, KOREA CHECK ACGIH TLV

CEL IN NEW ZEAIAND, SINGAPORE, VIETNAM CHECK ACGIH TLV

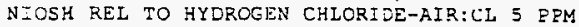

NIOSH* DHHS $\# 92-100,92$

NOHS 1974: HZD 38580 ; NIS 360 ; TNE 87434; NOS 156; TNE 824985

NOES 1983: HZD 38580; NIS 322; TNE E0309; NOS 183; TNE 1238572; TEE

388130

EFA GENETOX PROGRAM 1988, NEGATIVE: CEII TRANSEORM. -SA7/SHE

EPA ISCA SECTION 8 (B) CHEMICA.T INVENTORY

EPA TSCA SECTION B(D) UNPUBIISHED HEA.TH/SAEETY STUDIES

EPA TSCA SECTION B(E) RISK NOTIFICATION, 8EHQ-0892-9246

CN EPA IRIS DATABASE

EPA TSCA TEST SUBMISSION (TSCATS) DATA BASE, OCTOBER 1995

NIOSH ANALYTICAL METHOD, 1994: ACIDS, INORGANIC, 7903

U.S. INFORMATION

THIS RFODUCT IS SUBNECT TO SARA SECTION 313 REPORTING REQUIREMENTS. 
HNF-SD-RE-TPI-002, Rev. 0

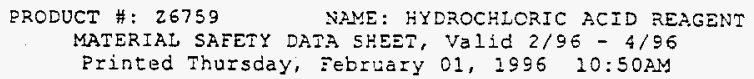


1. EXPERIMENTAL PRODUCT AND COMPANY IDENTIFICATION

PRODUCT: UOPTM IONSIVT Ion Exchanger TYpe IE-911

NOP

25 E Apenatin Fosd

Des Manut, it E0017-5017

Tolephone: 847.301-3189

FAX: 847.399 .2553

iolex: 211442

\section{COMPOSITION}

MATEEIAL

sulicion diexde

Titanium dicide

$13463-67 \cdot 7$

$1313-50.3$

Trade Secret

Trade Secret

1344-2B-1

(non-fibrous)

Copper axide

Calcium oxide

Chromium oxide

Magnesium oxde

\begin{tabular}{|c|c|c|}
\hline \\
\hline Usi: & UOP & $847 / 391-2123$ \\
\hline $\begin{array}{l}\text { Canada: } \\
\text { Ortside USA: }\end{array}$ & $\begin{array}{l}\text { Cheminee } \\
\text { Canuteo } \\
\text { Chemtree }\end{array}$ & $\begin{array}{l}800 / 424-\infty 300 \\
613 / 995-8600 \\
202 / 483-76: 0\end{array}$ \\
\hline
\end{tabular}

\section{MSDS\#053329}

1995-96 ACGIH TLV:TWA (I995 OSHA PEL-TNA)

$10 \mathrm{mg} / \mathrm{m}^{3}$ as $\mathrm{sl}$ tctal dust (15 mg/ $/ \mathrm{m}^{3}$ as SI iotal dust) ( $5 \mathrm{mg} / \mathrm{m}^{3}$ as Si respirable dusi)

$20 \cdot 40$

$10 \mathrm{mg} / \mathrm{m}^{3}$

(15 $\mathrm{mg} / \mathrm{m}^{3}$ as iespirable dusi)

$5-20$

None established

$15 \cdot 25$

None established

0.25

$5 \mathrm{mg} / \mathrm{m}^{3}$, STEL $10 \mathrm{mg} / \mathrm{m}^{3}$ $\left(5 \mathrm{mg} / \mathrm{m}^{3}\right.$, STEL $\left.10 \mathrm{mg} / \mathrm{m}^{3}\right)$

$10 \mathrm{mg} / \mathrm{m}^{3}$ total dust $5 \mathrm{mg} / \mathrm{m}^{3}$ respirable dust (15 $\mathrm{mg} / \mathrm{m}^{3}$ total dust) ( $5 \mathrm{mg} / \mathrm{m}^{3}$ respirable dust)

Q.2 None established

$0-2$

$2.0 \mathrm{mg} / \mathrm{m}^{2}$ $\left(5.0 \mathrm{mg} / \mathrm{m}^{2}\right)$

0. 2 None esteblished

0.2
$10 \mathrm{mg} / \mathrm{m}^{3}$ $\left(15 \mathrm{mg} / \mathrm{m}^{3}\right)$

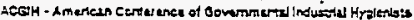

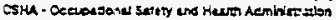

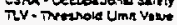

RV - Trezhole Umi Vowe

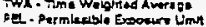

\section{HAZARDS IDENTIFICATION}

\section{FMERGENCY OVERVEW:}

This whita crystalline powder may cause skin and eye initatlon. Inhalation of dust may cause respiratory initation. Product is considered to have a low oral toxicty. 
Contact with sxin and eyes. Exposure may also oceur via inhalation or ingestion if product dust is generated durng handling. Product ingestion is unlikely but may occur if proper safety frysiene procedures ara not followed.

Skin Contac:

The solid or dust may cause irritation with repeated or prolonged exposure.

Eyo Contact:

Solid or dust may cause irritation or raddening due to mechanical action. Mid :o modera:e irtitation of eye membrane may also occur possibly resulting in swelling.

inhalation:

Way cause irritation of the nose and throat, accompenied by cough and chest discomfor. Frolonged inhalation may cause lung darnage.

ingestlen:

This product is considered to have a low order of toxichy.

Carcinogenlety Classification:

IARC: Titanium diexide and Silicon dicxica - Not dassifiable as humen carcinogens (Group 3). None of the othat components are classitied.

NTP: None of the product components are classified.

OSHA: None of the product components are classitied.

\title{
4. FIRST AID MEASURES
}

\section{MSDS \# 053329}

Skin: Wash affected area with soap and water. If irritation occurs, obtain medical attention.

Eyes: $\quad$ Fush with weter for at least 15 minties. If irritation persists, obtain meclcal attention.

inhalation: Femove affected perscn to iresh air. If breathing is difficult, oxygen may be needed; obtain medical attention.

Ingestion: Do not induce vomiting. Victim should drink large quantities of milk, gelatin soluilon or water. Obtain modical attertion.

\section{FIRE FIGHTING MEASURES}

\author{
Flash Point: Net applicable \\ Method: $\quad$ Not applicable \\ Extingulshing Media: Mateial dces not bum. Use media appropriate for surrounding fire (carbon dioxide, \\ dry chemical of fcam). \\ Fire and Explosion Hazard: Used material may contain products of a hazardous nature. The user of this product \\ must identity the hazards of the retalned meterial and infom the firs igiters of these \\ hazards.
}

\section{ACCIDENTAL RELEASE MEASURES}

isolate the affected area; restrict entry to the affected area io personnel wearing proper perscnal protectlve ecuipment. Speclal attention should be glven to respiritory and eye protection, because recovery of material can be expected to generate dust. Vacuum or shovel up spilled material, placing it into appropriate recovery drums or containers.

\section{HANDLING AND STORAGE}

Store in tightly closed, property labeled containers. Do not iake intemally. Avold repeated or prolonged contact whth skin. Avoid contact with eyes and inhalation of dust. 
$\therefore \because$

MAY 13 'S6 11:44AM LOP MT LALEE NJ
HNF-SD-RE-TPI-002, Rev. 0

P. 4/G

IONSIV IE-911

Page 3 of 5

January $19 \mathrm{gs}$

\section{EXPOSURE CONTROLS AND PERSONAL PROTECTION}

Respiratory: Where natural ventilation is inadequate, use mechanical ventilation, other engineening controls or a toxic dust respirator (in USA NICSH/MSHA-approved) to prevent inhalation of dust.

Sikn:

Chemical-resistert gloves and work uniform as necessary to prevent repeated or prolonged skin contact.

Eye: $\quad$ Safety glasses or goggles as necessary :o prevent eye contact.

9. PHIYSICAL AND CHEMICAL PROPERTIES

These data do nos represent tochniced or selor speciflestions.

Boiling Point:

Bulk Density:

Vapor Pressure:

Vaper Consithy:

Pour Point:

Freezing Point:

Specifle Gravity
Not applicable

Not avallable

Not applicable

Net applicable

Not applicable

Not applicable
Nct appileable
Solubliny in ivater:

\% Volatile:

Appearance:

Odor:

$\mathrm{pH}$ in 10\% aqueous slurry:

Physical State:

\section{STABILITY AND REACTIVITY}

Stabllty:

Condtitons il Ávoid:

Hazardous Decomposition Procucts:

Hazardous Polymerlzation:

incompatitio Materials:
Stable.

None knowr.

None.

Wid not occur.

Avoid conizct with acid and easiiy oxdized materials.

\section{TOXICOLOGICAL INFORMATION}

No data available for this product, the following data is for a similar product:

Cral LOSO

$>5 \mathrm{~g} / \mathrm{kg}$ (rat)

Eye irritation

The product is no more ihan moderstely irritating to the eyes of rabbits. No corneal damage was seen, lritis was seen in 2/6 animals after 1 hour, but none was seen after 48 hours. All 8 ratbils showed irritation of the conjunctiva after 1 hour, but after 72 hours only 1 still showed the irritation.

Skin Irritatlen

The product is no more than slighty iritating to the skin of rabbits; only tarely perceptible erythema was noted at the 1 -hr score time in $2 / 6$ rabblts, score of 1 for $2 / 6$ rabbits (maximum possible score is a).

Skin Sensitization

The product was found not to produce skin sensitization in guinea pigs.

Cytotoxleity

The product is classified in the nondetectable category according the IERL erotexicity scheme (Sandhu, 1979). The product was considered to be nencytotoxic to rabbit alveclar macrophage cells at concentrattons less than or ogual to $1000 \mu \mathrm{g} / \mathrm{ml}$.

\section{ECOLOGIC INFORMATION}

No data currenty avallable. 
HNF-SD-RE-TPI-002, Rev. 0

MA:' 13 'S5 1I: 4 AAM LICP MT LQUEEL NT

P. SRE

IONSN IE-911

Page 4 of 5

January 1996

13. DISPOSAL CONSIDERATIONS

Dispase of product in accordence with all epplicable government regulations. The unused product and its components are not listed by generic name or trademark name in the U.S. EPA's Resourca Conservation and Recovery Act (RCRA) Hazardous Wasto Manegement Alegularlons and do not possess any of the four ldentifying characteristla; of hazardous waste.

\section{TRANSPORTATION INFORMATION}

DOT Hazard Classification: Not Regulated

ID Number:

IMO Hazard Classtileston:

1D Number:
Not Applicable

Not Regulated

Not Applicable

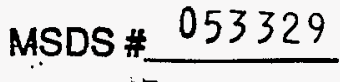

sin-

\section{REGULATORY INFORMATION}

U.S. TOXIC SUBSTANCES CONTROLACT TSCA): All the ingredistts of this product are registered in accordance with TSCA

U.S. SUPERFUND AMENDMENTS AND REAUTLCRIZATCN ACT (SARA) TITLE III, SECTION 313: The following component(s) In this product is stbject to the reporting requirements of section 313 of the Emercency Planning and Community Right-To-Krow ACt, 40 CFR 372: -none-

EUROPEAN INVENTOAY OE EXISTING COMMERCIAL CHEMICAL SUBSTANCES (EINECS): The components of this reparation aro included on the EINECS.

$\begin{array}{ll}\text { Silicon cloxlde } & 2315454 \\ \text { Titanium dicxide } & 2366755 \\ \text { Sodium oxide } & 2152089 \\ \text { Trade Secrat Waterial } & \text { listed } \\ \text { Trade Secret Materlal } & \text { listed } \\ \text { Aluminum cxde } & 2156916 \\ \text { Copper cxide } & 2132691 \\ \text { Calcium oxide } & 2151389 \\ \text { Chromium oxide } & 2151609 \\ \text { Magnesium cxide } & 2151719\end{array}$


16. OTHER INFORMATION

For additional information concerning this product contect the following:

For health, safety \& environmentai

informatlon, please contact:

Product Sterardship Manager

Health, Safety and Environmental Department

UOP

25 E. Algonçin Rd.

Ces Plaines, IL 60017.5017

Tolephone: (B47) 3913120

Fax: $(847) 391-2953$
For tochnical or product püctrasing information, please contact:

\author{
Account Marager \\ UOP \\ 307 Feilowship Rcad \\ Sutte 207 \\ Nit Laurel, New Jersey 08054 \\ Telephone: (609) 727.9400 \\ - Fax: $(\infty 09) 727-9545$
}

\section{PRODUCT EMERGENCIES}

If you have a product-related emergency, resuhing in an incident such as a spill or relesse of product, human exposure, etc., and need assistance frem UOP, please call us at the following number:

\section{Hour EMERGENCY Telephone Number: (847) 391-2123}

The data and recommendatlons preserted in this data sheet concerning the use of our product and the materlals contained therein are belleved to be accurate and are besed on irformation which is considered relleble as of the date herecf. However, the cusicmer shouid deiermine the sutability of such materials for his purpcse before adopting ithem on a commercial seale. Since the use of our products by others is beyond our control, no guarantae, express or implled, is made and no responsibility assumed for the use of this material or the results to be obtained therefrom. Information on this iorm is furnished for the purpose of compliance with Government Health and Safery Regulations and shall not be used for any cther purposes. Moreover, the recommendations contained in this deta sheet are not to be constnjed as a license to operate under, or a recommendation to infringe, any existing patents, nor should they be contused with state, municipal or insurance requirements, or with national safery codes.

UOP

Date: January 1998

Revision: I

Supersedes: February 1995 
HNF-SD-RE-TPI-002, Rev. 0

THIS PAGE INTENTIONALLY LEFT BLANK 
HNF-SD-RE-TPI-002, Rev. 0

Appendix C: Valving Configuration Figures

C-i 
HNF-SD-RE-TPI-002, Rev. 0

THIS PAGE INTENTIONALLY LEFT BLANK

C-ii 


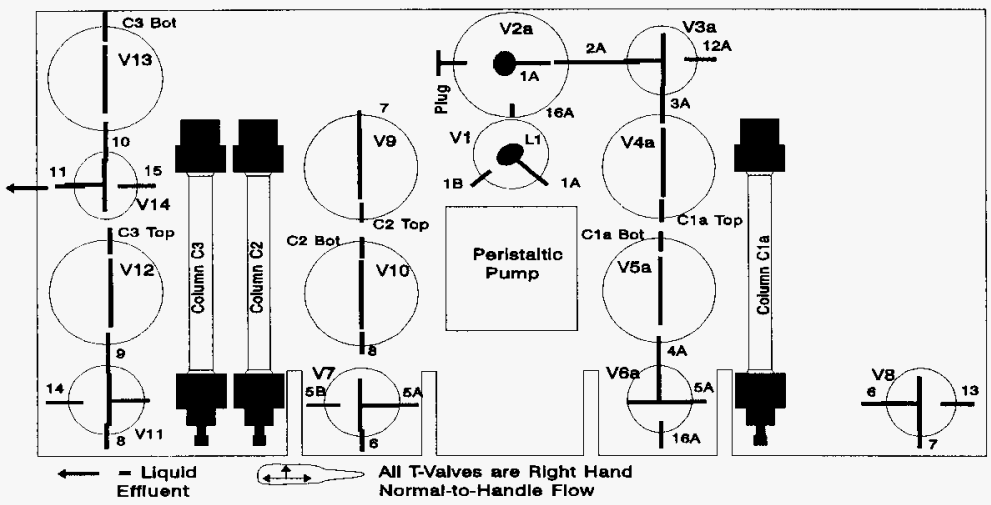

Figure C-1: Config. 1A, Primary Column (C1a) Full System Feed Valving

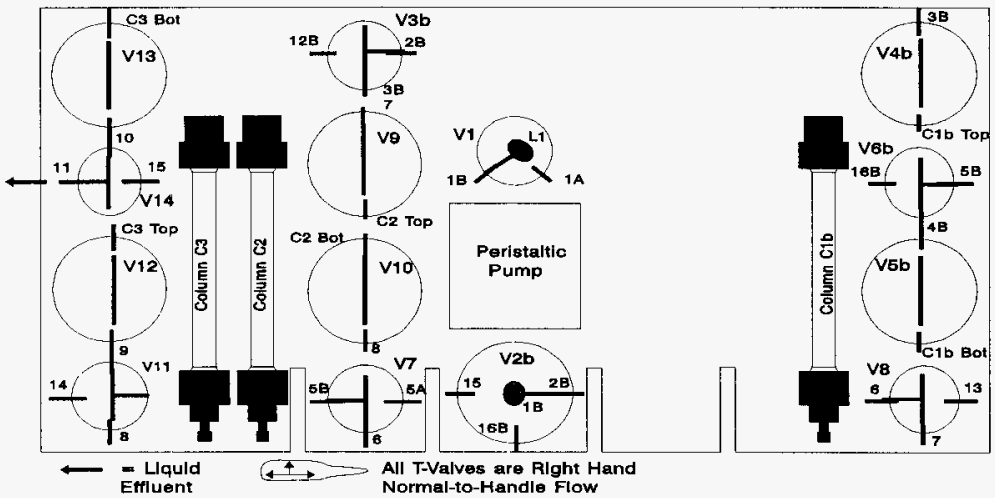

Figure C-2: Config. 1B, Backup Column (Clb) Full System Feed Valving 


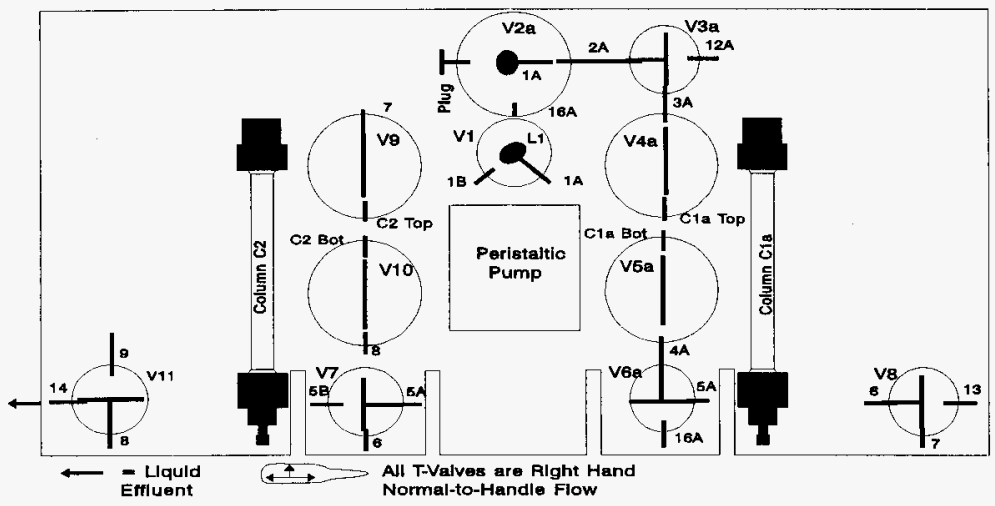

Figure C-3: Config. 2A, Forward Feed through Primary and First Guard Columns

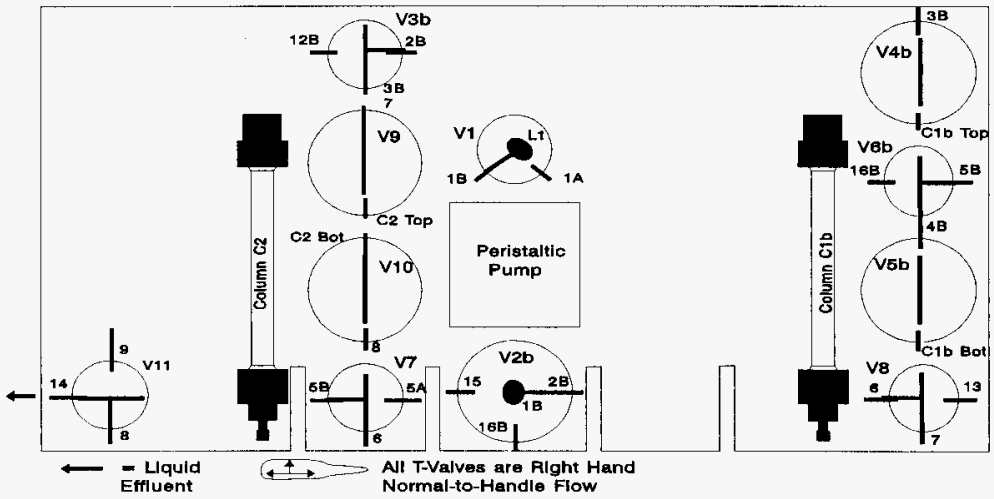

Figure C-4: Config. 2B, Forward Flow Through Backup and First Guard Columns 


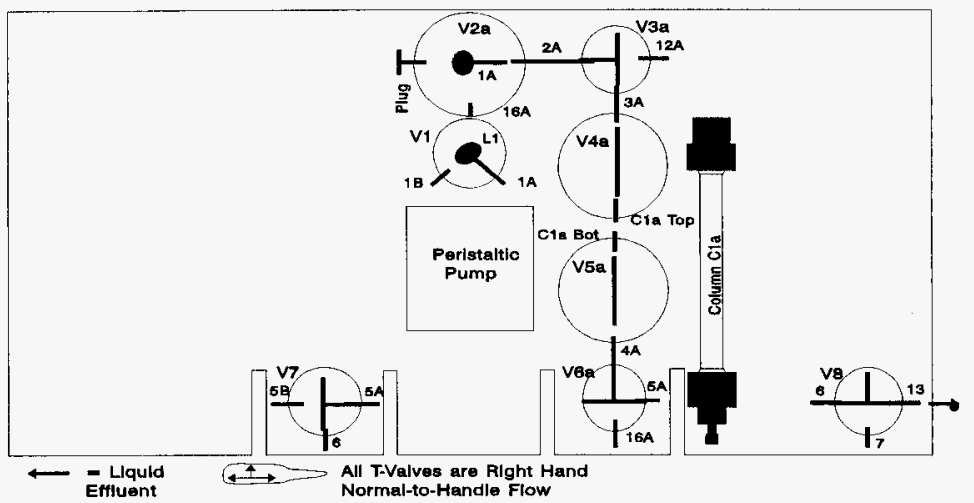

Figure C-5: Config. 3A, Forward Flow Through Primary (C1a) Column to Sample

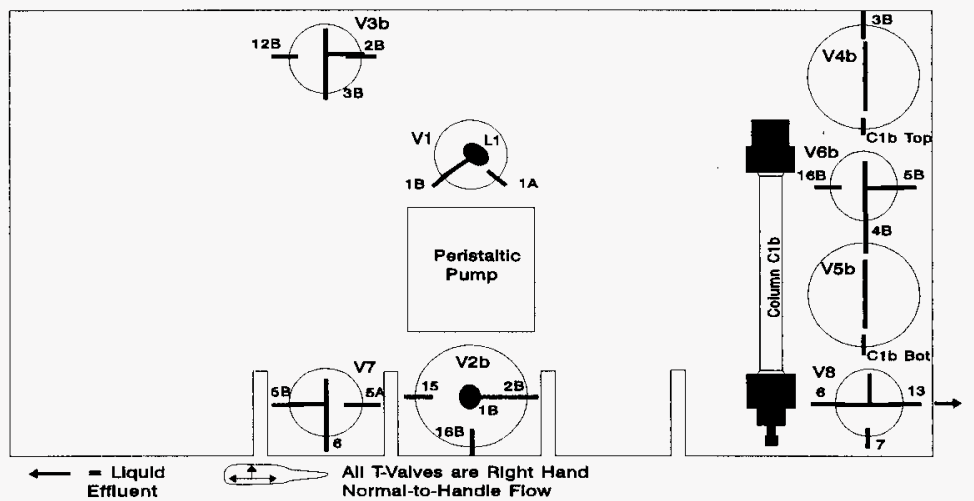

Figure C-6: Config. 3B, Forward Flow Through Backup (Clb) Column to Sample 


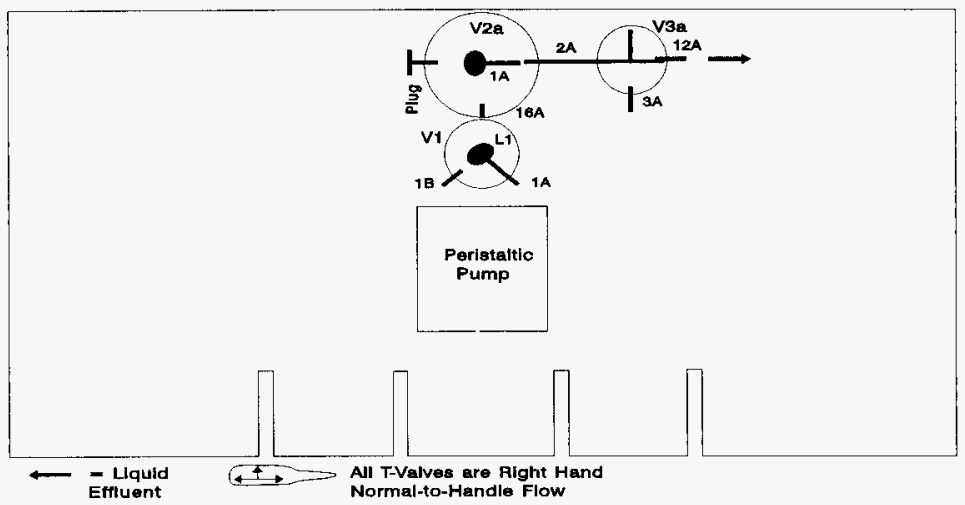

Figure C-7: Config. 4A, Forward Flush Bypass to Line 12A

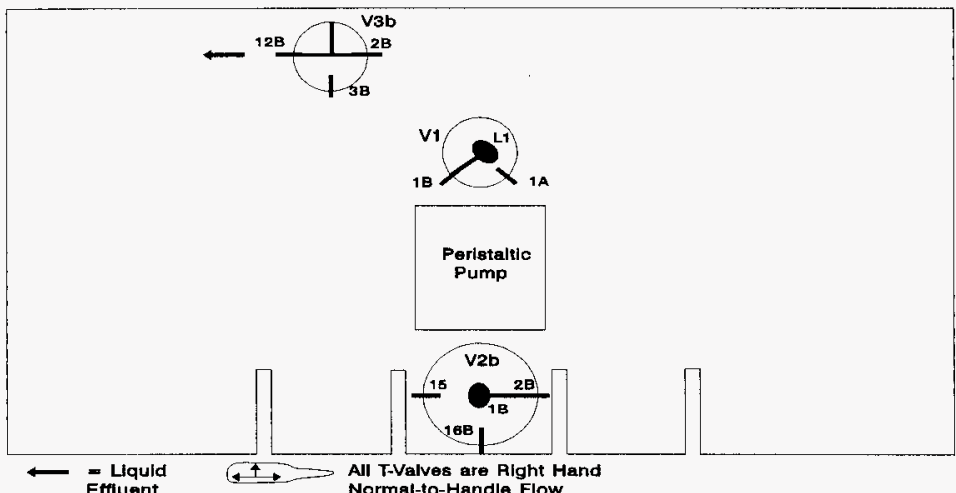

Figure C-8: Config. 4B, Forward Flush Bypass to Line 12B 


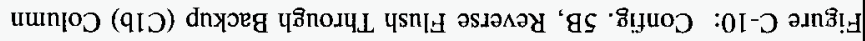

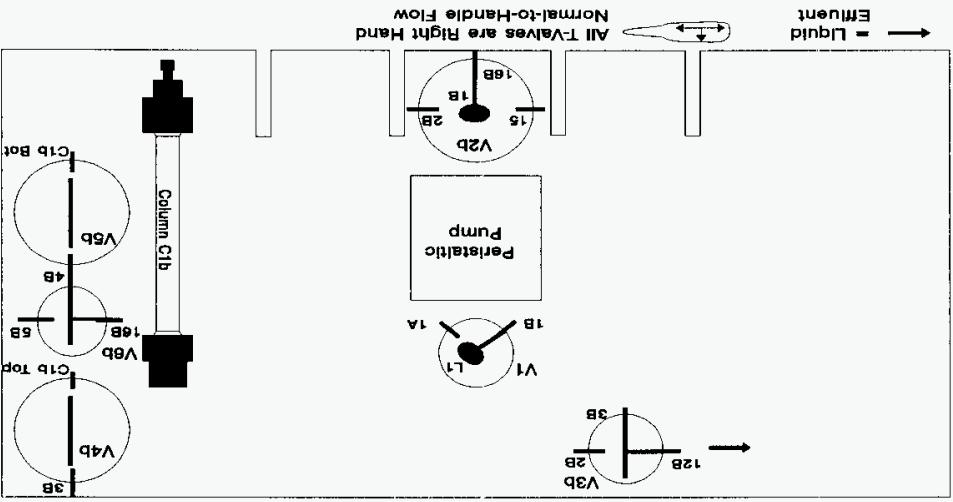

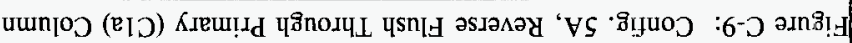

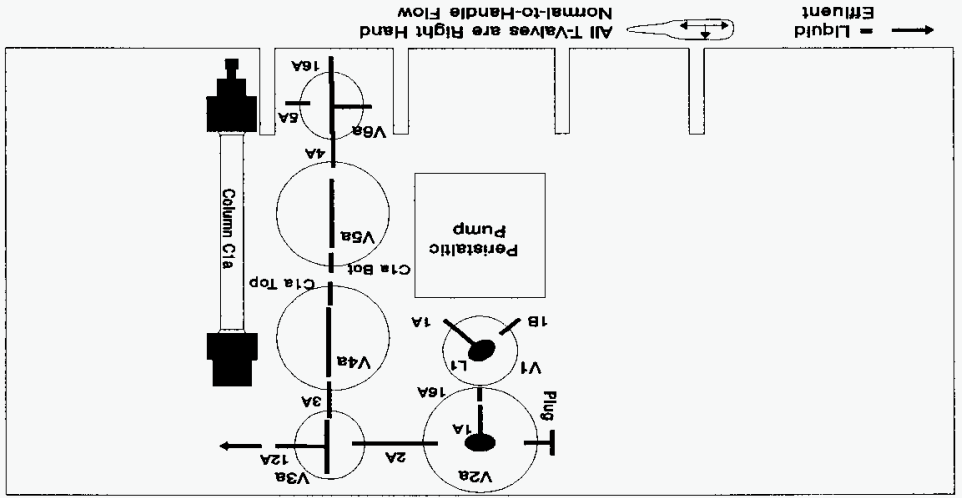




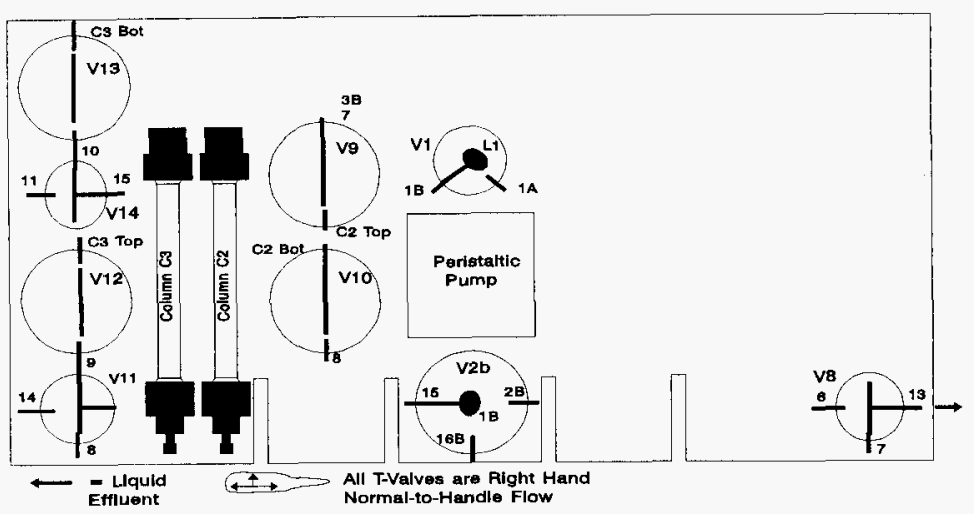

Figure C-11: Config. 6, Reverse Flush Through Guard Columns (C3 and C2) 
HNF-SD-RE-TPI-002, Rev. 0

Appendix D: Gamma Probe Operation

D-i 
HNF-SD-RE-TPI-002, Rev. 0

THIS PAGE INTENTIONALLY LEFT BLANK

D-ii 


\section{GENERAL INSTRUCTIONS BETA/GAMMA HOT CELL PROBE VERSION 1.0}

\section{INTRODUCTION}

This desk instruction provides checklist-style guidance on producing data with the beta/gamma hot cell probe. This instruction assumes the person has read the GammaVision $^{\mathrm{TM}}$ software manual, and understands the basics of Microsoft Windows ${ }^{\mathrm{I}}$ operating system as well as nuclear spectroscopy.

Setup:

Cable connections:

Ensure that all power cables are connected.

Ensure that cables to the probe are connected.

Powering up:

Ensure that both bias power supplies are switched to OFF and set to 0 volts (V). Reset the beta detector bias supply if necessary.

Turn on the main power switch at the bottom of the relay rack.

Turn on the bottom NIM bin.

Turn on the computer (the bottom NIM bin power MUST be on).

Turn on the top NIM bin.

Turn on the gamma detector bias supply (top NIM bin). Slowly raise the voltage up to $800 \mathrm{~V}$ Positive.

Plug the beta amplifier (Top NIM crate, Canberra Fast ${ }^{2}$ spectroscopy amp) output to an oscilloscope.

Trademark of Microsoft Corporation, Redmond, Washington.

Trademark of Canberra Industries, Inc., Meridian, Connecticut. 
HNF-SD-RE-TPI-002, Rev. 0

Place a source under the beta detector. This may be needed to provide enough counts to see in the oscilloscope.

Turn on the beta detector bias supply (bottom NIM crate). Very slowly

$(<20 \mathrm{volts} / \mathrm{sec})$ raise the beta detector bias voltage to $800 \mathrm{~V}$, waiting until the pulse on the oscilloscope returns to normal before proceeding.

When the beta detector bias voltage is at $800 \mathrm{~V}$, reconnect the amplifier output to the $\mathrm{T}$-connector at channel 2 of the single-channel analyzer (SCA).

Turn the pointer on (up). The switch is in a blank NIM module in the top NIM bin.

Starting GammaVision ${ }^{\mathrm{TM}}$

At the C: prompt, enter "win" to enter Windows ${ }^{\mathrm{TM}}$.

Double-click on the GammaVision ${ }^{\mathrm{TM}}$ icon.

Switch to multichannel buffer (MCB) \#1 (gamma) if not already there.

Run job "gatelcn.job".

Switch to MCB \#5 (beta).

Run Job "gate5off.job"

Spectrometry:

Taking a spectrum in GammaVision ${ }^{\mathrm{TM}}$ is as easy as hitting ALT2 (STOP), ALT3 (CLEAR), ALT1 (START), and giving the program all the information it requests. GammaVision $^{\mathrm{TM}}$ is set up to ask for collection live time and sample description.

Spectra for most samples will be taken using an automated .JOB file, which only requires the user to input live time and sample description.

Running the counters:

When you are ready to start a count, hit the stop button (or switch) on the timer, then hit the reset (to clear previous counts), and then hit the start button (switch) to start the count. 
Daily Energy Calibration and QA Check

Perform startup.

Center the ${ }^{154} \mathrm{Eu}$ quality assurance (QA) source under the probe (at the intersection of the light beams of the pointer).

Set the live time on the MCBs and counters to 2,000 seconds.

Start the counters and the MCBs.

ON MCB \#1, Recall qaeusrc.roi.

Compare the peak centroids to the published values for ${ }^{154} \mathrm{Eu}$.

If the centroids of the peaks are shifted from the published values by more than $10 \mathrm{keV}$, adjust the amplifier fine gain to match the centroids with published values.

Stop and start the MCBs between adjustments of the fine gain controls.

If the actual values are more than $30 \mathrm{keV}$ apart, consult with the scientist on whether a recalibration is necessary.

Compare the endpoint of the beta spectrum taken to the file C:IbetaprolSrtdQA1.chn. If the endpoint is different, adjust the fine gain on the Canberra amplifier.

After completing the calibration and QA check, take a spectrum with both MCBs.

Run .JOB file C: Imcafile\QAcheck.job.

At the end of the count record all counter values.

Compare the current QA check source values to previous QA counts; the values should be within $20 \%$. The values below are from page 10 (repeated on page 37 ) of laboratory notebook WHC-N-11151 1 (Beck 1994), and the spectra files: Gamma, CldatalgamprolsrtdQA.chn; Beta, C:IdatalbetaprolsrtdQA1.chn.

Total Beta (TB): 2,073,772 Betas Above Gammas (BAG): 377

Total Gamma (TG): $1,448,951 \quad$ Gammas Above Cesium (GAC): 215,372

Cesium-137 (Cs): $\quad 72,892$

Eu-154@248 keV 385,290 counts, @723 keV

85,423 counts@993 keV 10,671 counts@@1274 keV 5,667 counts 


\section{Rurnning Samples:}

If the daily QA check is $\mathrm{OK}$, then samples may be run.

Run the .JOB file gammaV5.job .

Rernember which scan you're on.

Scans 1 and 7 are backgrounds, so the sample must be moved away from the probe during those scans.

Label the scans appropriately at $0.5,5,9.5,14$, and 18 inches from the bottom of the core segment.

Align the sample with the laser beam crosshairs so as to position the sample for scans 2 through 6 .

Return the sample to 11A Hot Cell Operations personnel.

After the end of the run (including backgrounds), start Quattro Pro ${ }^{\mathrm{TM}}$.

Open the file appropriate to the geometry of the sample. LogSS5.WQ1 should be used for "log" samples, and TraySS\#3.WQ1 for "tray" (flat) samples.

\section{Hit Alt A.}

Change the text on the 2nd line of the graph to reflect the identity and nature of the sample.

Print-to-Fit and Print Graph. There is no need to change any settings before printing, as everything is already set up.

Save the Quattro Pro ${ }^{\mathrm{TM}}$ file in a directory appropriately named for the sample.

In Windows ${ }^{\mathrm{TM}}$ File Manager, copy all the files in the directory

\section{C:Ipractjob}

to a directory that is labeled in such a way as to identify the sample.

Paste all the output into the laboratory notebook.

You're done!... 
Normal Shutdown:

Shut the pointer off.

Normally, everything else is left on.

Total Shutdown:

Perform the normal shutdown.

Exit Windows ${ }^{\mathrm{TM}}$.

Shut off the computer.

Slowly turn the bias supply voltages down to 0 and lock them there.

Turn off the bias supplies.

Turn off the NIM bins.

Turn off the fans (back of rack).

\section{REFERENCES}

Beck, M. A., 1994, Controlled Laboratory Notebook, Hot Cell Beta/Gamma Probe, WHC-N-120 7, Westinghouse Hanford Company, Richland, Washington.

Beck, M. A. et al. WHC-SD-WM-DTR-039 is the source of this instruction set. 
DISTRIBUTION SHEET

\begin{tabular}{|c|c|c|c|c|c|}
\hline \multirow{2}{*}{$\begin{array}{l}\text { To } \\
\text { Distribution }\end{array}$} & \multirow{2}{*}{\multicolumn{3}{|c|}{$\begin{array}{l}\text { From } \\
\text { SESC/PE }\end{array}$}} & \multicolumn{2}{|l|}{ Page 1 of 1} \\
\hline & & & & \multicolumn{2}{|c|}{ Date $1 / 06 / 97$} \\
\hline \multicolumn{4}{|l|}{ Project 7itle/Work Order } & \multicolumn{2}{|c|}{ EDT No. 605786} \\
\hline \multicolumn{4}{|c|}{$\begin{array}{l}\text { CSeium Flow Studies at Hanford/ Complexed Concentrate Cesium } \\
\text { Removal using CST }\end{array}$} & \multicolumn{2}{|l|}{ ECN No. } \\
\hline Name & MSIN & $\begin{array}{c}\text { Text } \\
\text { With All } \\
\text { Attach. }\end{array}$ & Text Only & $\begin{array}{l}\text { Attach./ } \\
\text { Appendix } \\
\text { Only }\end{array}$ & $\begin{array}{l}\text { EDT/ECN } \\
\text { Only }\end{array}$ \\
\hline
\end{tabular}

Akita, R.

Appel, J. N.

Babad, $H$.

Beck, M. A.

Biyani, R. K. (2)

Duncan, J. B. (2)

Edmonson, D. W.

Hendrickson, D. W. (7)

Hunter, J. A.

Hyatt, J. E.

Kurath, D. E. (3)

Jewett, J. R.

Lamson, S. B.

McDonald, G. T.

Warwick, G. J.

TCRC (2)

Central Files (orig +2 )

$\begin{array}{ll}\text { T6-20 } & X \\ \text { G3-21 } & X \\ \text { S7 }-14 & X \\ \text { T6-09 } & X \\ \text { L5-31 } & X \\ \text { L5-55 } & X \\ \text { T6-09 } & X \\ \text { L5-31 } & X \\ \text { L5-31 } & X \\ \text { S3-31 } & X \\ \text { P7-20 } & X \\ \text { T6-09 } & X \\ \text { T6-28 } & X \\ \text { L5-31 } & X \\ \text { T6-12 } & X \\ \text { R2-12 } & X \\ \text { A3-88 } & X\end{array}$

